\title{
Statistical prediction of fracture parameters of concrete and implications for choice of testing standard
}

\author{
Zdeněk P. Bažant ${ }^{\mathrm{a}, *}$, Emilie Becq-Giraudon ${ }^{\mathrm{b}}$ \\ ${ }^{a}$ Department of Civil Engineering and Materials Science, Northwestern University, Evanston, IL 60208, USA \\ ${ }^{\mathrm{b}}$ Northwestern University, USA
}

Received 4 December 2000; accepted 26 October 2001

\begin{abstract}
This article shows how the fracture energy of concrete, as well as other fracture parameters such as the effective length of the fracture process zone, critical crack-tip opening displacement and the fracture toughness, can be approximately predicted from the standard compression strength, maximum aggregate size, water-cement ratio, and aggregate type (river or crushed). A database, consisting of 238 test data, is extracted from the literature and tabulated, and approximate mean prediction formulae calibrated by this very large data set are developed. A distinction is made between (a) the fracture energy, $G_{\mathrm{f}}$, corresponding to the area under the initial tangent of the softening stress-separation curve of cohesive crack model, which governs the maximum loads of structures and is obtained by the size effect method (SEM) or related methods (Jenq-Shah two-parameter method and Karihaloo's effective crack model, ECM) and (b) the fracture energy, $G_{\mathrm{F}}$, corresponding to the area under the complete stress-separation curve, which governs large postpeak deflections of structures and is obtained by the work-of-fracture method (WFM) proposed for concrete by Hillerborg. The coefficients of variation of the errors in the prediction formulae compared to the test data are calculated; they are $17.8 \%$ for $G_{\mathrm{f}}$ and $29.9 \%$ for $G_{\mathrm{F}}$, the latter being 1.67 times higher than the former. Although the errors of the prediction formulae taking into account the differences among different concretes doubtless contribute significantly to the high values of these coefficients of variation, there is no reason for a bias of the statistics in favor of $G_{\mathrm{f}}$ or $G_{\mathrm{F}}$. Thus, the statistics indicate that the fracture energy based on the measurements in the maximum load region is much less uncertain than that based on the measurement of the tail of the postpeak load-deflection curve. While both $G_{\mathrm{f}}$ and $G_{\mathrm{F}}$ are needed for accurate structural analysis, it follows that if the testing standard should measure, for the sake of simplicity, only one of these two fracture energies, then $G_{\mathrm{f}}$ is preferable. (C) 2002 Elsevier Science Ltd. All rights reserved.
\end{abstract}

Keywords: Concrete; Fracture; Fracture energy; Testing; Statistics; Scatter; Randomness; Uncertainty; Prediction; Standards; Size effect

\section{Problem faced and its history}

After a quarter century of intense research, it has now become clear that the use of fracture mechanics can yield safer and more efficient design against all kinds of brittle failures of concrete structures. This conclusion is now supported by extensive analytical studies and numerous scaled-down laboratory tests, as well as a few full-scale field tests. The importance of adopting fracture mechanics is underscored by recent studies of some well-known structural catastrophes. A few examples deserve to be noted:

1. The toppling of the Hanshin Viaduct in Kobe during the Hyogo-Ken Nambu earthquake in 1995 was

* Corresponding author. Tel.: +1-847-491-4025; fax: +1-847-491-3741.

E-mail address: z-bazant@northwestern.edu (Z.P. Bažant). caused primarily by softening fracture at the compression side due to bending of massive columns. Although the primary cause of collapse was insufficient confining reinforcement, the size effect was a major contributing factor, causing the nominal strength in compression fracture of the columns subjected to bending to be about $38 \%$ less than the standard compression strength determined on the basis of standard size test cylinders. Similar observations can be made about various bridge columns that failed in the Northridge earthquake in Los Angeles in 1994.

2. The failure of the Cypress Viaduct in Oakland, CA, during the 1989 Loma Prieta earthquake. Although the primary cause of failure was again insufficient confining reinforcement, the size effect must have reduced 
the nominal strength of concrete failing in compression to $30 \%$ less than the value assumed in design.

3. The failure of the Malpasset Arch Dam in the French Maritime Alps in 1959. Although the main cause was excessive movement of rock in left abutment, the size effect on bending fracture of plain concrete caused the maximum tolerable movement to be about $55 \%$ less than the prediction on the basis of laboratory strength tests. A similar observation can be made about the failure of San Francis dam near Los Angeles in 1928.

4. The failure of Schoharie Creek Bridge on New York Thruway, which was caused by fracture of a foundation plinth during a flood in 1987. Although the main cause was an unexpected scouring of the river bottom, the size effect on bending fracture of plain concrete caused the nominal tensile strength of the unreinforced plinth to be about $46 \%$ less than the tensile strength determined in standard laboratory tests.

5. The sudden explosive failure of Sleipner A oil platform in 1991 during submergence test in a Norwegian fjord - a disaster with no loss of life, but a cost of about US\$300 million, which was caused by diagonal shear failure of a very thick tri-cell wall. Although the layout of the reinforcement was incorrect and the elastic finite element analysis had an error of about $40 \%$, it has been estimated that the size effect decreased the nominal shear strength by about $34 \%$.

Although fracture mechanics was originated by Griffith already in 1921, for half a century, it was considered inapplicable to concrete. This is not surprising because a very different fracture mechanics theory is needed for concrete than for homogeneous structural materials such as fatigued steel or ceramics. The study of fracture mechanics of concrete originated in 1961 with Kaplan [53]. Kesler et al. [57] concluded in 1971 that the classical linear elastic fracture mechanics (LEFM), with only one fracture parameter, the fracture energy $G_{\mathrm{f}}$ (or the fracture toughness $K_{\mathrm{c}}$ ), was inapplicable to concrete. At least two fracture parameters are required. This transpired in 1976 from the studies of smeared-cracking finite element models [6] and notched fracture tests [46] (also Ref. [43]), and was recognized in the development of the crack band model [6,21], in which the fracture properties are characterized by the average slope of the postpeak strain softening tied to a certain characteristic width of the crack band front (which together imply a certain fixed value of fracture energy $G_{\mathrm{f}}$ ).

A major step was made by Hillerborg et al. [46] who introduced to concrete the cohesive (or fictitious) crack model, in which the initial slope of the softening stressseparation curve or the area under the curve, together with the tensile strength, implies two independent basic fracture parameters of the material. Two parameters were subsequently used in Karihaloo and Nallathambi's [54-56,67] effective crack model (ECM) and in Jenq and Shah's "twoparameter model" (TPM) [51]
Practically, the most important attribute of fracture mechanics of concrete is the size effect. Although in the solid mechanics and structural design communities it was widely believed until the mid-1980s that all the size effects were of statistical origin, and should therefore be relegated to statisticians, Leicester in 1969 [58] suggested the idea that the size effect in concrete may originate from fracture mechanics. Walsh in 1972 [89] demonstrated experimentally that similar notched concrete specimens with similar large cracks or notches exhibited a strong size effect that was transitional between the case of no size effect for small sizes and the case of LEFM size effect for large sizes.

The source of the size effect was recognized to be the softening damage of the material in a large fracture process zone. Failures caused by fracture were numerically simulated with the crack band model [6,21], and were described in 1984 [7] by a simple size effect formula, justified by asymptotic arguments. Subsequently it was shown that the knowledge of the size effect law implies the fracture characteristics. If the classical size effect law [7] is fit to the maximum load data (which is adequate for a size range only up to about 1:30), two fracture characteristics can be determined - the fracture energy and the effective length of the fracture process zone [22]. The latter was later shown to be related to the critical crack-tip opening displacement used in TPM [16]. Asymptotic analysis further showed that the fracture model based on the size effect law and the JenqShah's TPM give about the same size effect and, therefore, are approximately equivalent $[9,23,70]$. Likewise, ECM was shown to be approximately equivalent to TPM, and thus to the size effect model. The reason that these three models yield similar results is that all the measurements are conducted at or near the maximum load.

The fracture energy normally associated with the cohesive crack model, $G_{\mathrm{F}}$, is different from $G_{\mathrm{f}}$. It is determined as the area under the entire measured load-deflection curve, divided by the ligament area. The $G_{\mathrm{F}}$ values obtained by this method, called the work-of-fracture method (WFM), are quite sensitive to the specimen size and shape, although this might perhaps be avoided by very careful evaluation of the tail of the load-displacement curve and of all the energy dissipation sources in the test (see Guinea et al. [40]). On the other hand, fracture energy $G_{\mathrm{f}}$ determined by the size effect method (SEM) is, by definition, independent of the structure size as well as geometry [22,23]. Significant changes in the testing size range will nevertheless affect the $G_{\mathrm{f}}$ value obtained (this could in principle be avoided by using the broadrange size effect law, with a series of fracture energies [13].

While $G_{\mathrm{F}}$ corresponds to the area under the complete softening stress-separation curve of the cohesive crack model, the fracture energy of the size effect model denoted as $G_{\mathrm{f}}$, corresponds to the area under the initial tangent of the stress-separation curve (Fig. 1). Planas and Elices [74] estimated $G_{\mathrm{F}} / G_{\mathrm{f}} \approx 2.0-2.5$ (see also Ref. [23]). It was also realized that these two fracture energy definitions are appropriate for different objectives $-G_{\mathrm{f}}$ is suitable and 


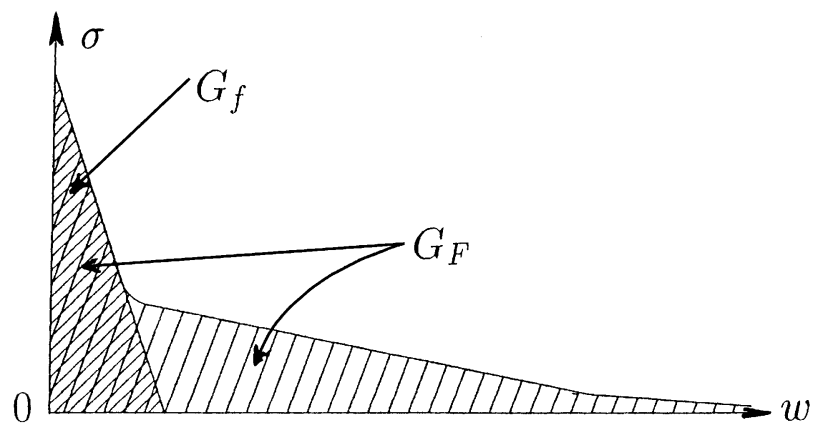

Fig. 1. Softening stress-separation curve of cohesive crack model and areas representing $G_{\mathrm{f}}$ and $G_{\mathrm{F}}$.

entirely sufficient for predicting the maximum loads of structures (as well as the load-deflection curves up to the peak), while $G_{\mathrm{F}}$ is suitable and necessary for calculating the energy dissipation in total failure of structures and for determining the tail of the postpeak softening load-displacement diagram of a structure [14].

Since the test results from different laboratories, based on different fracture specimens and different methods, exhibit very large scatter, it has widely been considered futile to attempt predicting the fracture energy of concrete and other fracture characteristics from the mix parameters and the strength, bypassing the tests of notched fracture specimens. Several previous attempts to set up such formulae, admittedly rather crude, have nevertheless been made, as described in Appendix B. However, these older formulae have been based on a much more limited set of test data than those that can today be collected from the literature.

The database acquired in concrete fracture testing worldwide has by now become enormous. Thus, the time seems ripe for the goal of this study - evaluate all these data statistically in order to determine whether an improved formula for fracture energy could be formulated, and whether an additional formula (apparently not yet attempted) to predict the second parameter of quasibrittle fracture, such as the fracture process zone size, could be developed. While it is clear that estimation of fracture parameters from nonfracture tests can never replace fracture testing of notched specimens, an improved formula with a known standard deviation can nevertheless serve a useful purpose for preliminary design and for approximate analysis of structures with not too high fracture sensitivity.

\section{Choice of prediction formulae}

The fracture energy $G_{\mathrm{f}}\left(\right.$ or $\left.G_{\mathrm{F}}\right)$ and the effective length of fracture process zone, $c_{\mathrm{f}}$, may be expected to be related to the basic simple characteristics of concrete by equations of the type:

$$
\begin{aligned}
& \phi\left(G_{\mathrm{f}}, f_{\mathrm{c}}^{\prime}, d_{\mathrm{a}}, w / c, E, \rho\right)=0 \text { and } \\
& \psi\left(c_{\mathrm{f}}, f_{\mathrm{c}}^{\prime}, d_{\mathrm{a}}, w / c, E, \rho\right)=0
\end{aligned}
$$

where $\phi$ and $\psi$ are certain functions, $d_{\mathrm{a}}$ is the maximum aggregate size, $w / c$ is the water-cement ratio (by weight), $E$ is the Young's modulus, $\rho$ is the unit weight of concrete, and $f_{\mathrm{c}}^{\prime}$ is the mean value of standard 28-day cylindrical compression strength, based on cylinders 6 in. $(15 \mathrm{~cm})$ in diameter and 12 in. $(30 \mathrm{~cm})$ in length (for some of the tests included in the statistical evaluation discussed later, the cubic compression strength was reported; its value was converted to the cylindrical strength using the standard approximate formula).

The parameters in Eq. (1) may be grouped into the following dimensionless parameters (Eq. (2)):

$$
\begin{aligned}
& \rho d_{\mathrm{a}} / f_{\mathrm{c}}^{\prime}, E / f_{\mathrm{c}}^{\prime}, E G_{\mathrm{f}} / f_{\mathrm{c}}^{\prime 2} d_{\mathrm{a}}, f_{\mathrm{c}}^{\prime} / \rho d_{\mathrm{a}}, G_{\mathrm{F}} / E d_{\mathrm{a}}, \\
& G_{\mathrm{F}} / f_{\mathrm{c}}^{\prime} d_{\mathrm{a}}, G_{\mathrm{F}} / \rho d_{\mathrm{a}}^{2}, \quad c_{\mathrm{f}} / d_{\mathrm{a}}, \quad c_{\mathrm{f}} \rho / f_{\mathrm{c}}^{\prime}, \quad c_{\mathrm{f}} \rho / E .
\end{aligned}
$$

According to Buckingham's theorem of dimensional analysis, any physical phenomenon must, in theory, be reducible to an equation in terms of dimensionless parameters whose number is equal to the total number of parameters, which is six in each of these equations, minus the number of parameters with independent dimensions, which is two (length and stress). Thus, only four of the aforementioned dimensionless ratios are, in theory, allowed to appear in the prediction equations for $G_{\mathrm{f}}$ and $c_{\mathrm{f}}$. A number of simple relations of this kind have been formulated and compared to the existing test data. However, clear statistical trends could not be detected.

It must, therefore, be concluded that the six parameters listed in functions $\phi$ and $\psi$ are insufficient to characterize the relationship fully. This means that the Buckingham theorem cannot be applied and some of the parameters may thus have physical dimensions. As we will see, aside from three dimensionless parameters $\alpha_{1}, \alpha_{2}$, and $\alpha_{3}$, we will need two additional parameters with physical dimensions. We will also drop parameter $E$, because it is strongly related to $f_{\mathrm{c}}^{\prime}$, which in turn is strongly related to $w / c$. Further, we will drop parameter $\rho$-not because it would be insignificant but because the vast majority of the existing data pertains to normal-weight concretes. Thus, we will seek $G_{\mathrm{f}}$ and $c_{\mathrm{f}}$ as empirical functions of $f_{\mathrm{c}}{ }^{\prime}, d_{\mathrm{a}}$, and $w / c$, to which we will add parameter $\alpha_{0}$ depending on the type of aggregate - crushed or river aggregate (see Appendix A).

It might seem that the tensile strength $f_{\mathrm{t}}^{\prime}$, the modulus of rupture $f_{\mathrm{r}}$, or the Brazilian split-cylinder strength $f_{\mathrm{sc}}$ would be better parameters than $f_{\mathrm{c}}{ }^{\prime}$. However, measurement of the direct tensile strength is difficult and more sensitive to statistical size effect than $f_{\mathrm{c}}^{\prime}$, while the modulus of rupture is subject to a strong deterministic and statistical size effects [19]. As for $f_{\mathrm{sc}}$, one might suspect it to be unduly influenced by large compressive stress parallel to the splitting plane and by frictional plastic deformation near the contact with the loading strips, although this has not been proven. Besides, a greater obstacle is that only very few of the reports on fracture tests in the literature give information on the values 
of these parameters, rendering a systematic calibration of a formula with these parameters impossible. Similarly, many of the fracture data unfortunately miss the measurement of $E$, which is another reason for omitting that parameter.

In the case of $c_{\mathrm{f}}$, the main influencing parameters might of course be different than in the case of $G_{\mathrm{f}}$. Other parameters such as the air content, aggregate-sand ratio, grain size distribution, porosity, relative strength and stiffness of the aggregates, etc., might seem more appropriate to predict $c_{\mathrm{f}}$. Nevertheless, these parameters could not be considered, not only for $c_{\mathrm{f}}$ but also for $G_{\mathrm{f}}$, due to lack of information in the published reports on the tests.

The formula should preferably be such that, among the chosen parameters, as many as possible should be identifiable from the test data by linear regression. The simplest relationship of this type would be $G_{\mathrm{f}} \approx \alpha_{1} f_{\mathrm{c}}^{\prime}+\alpha_{2} d_{\mathrm{a}}+\alpha_{3}(w / c)+\alpha_{4}$, in which $\alpha_{i}(i=1,2, \ldots)$ are the parameters of the prediction formula. However, this form is unsuitable because an extension of the range could give negative values of $G_{\mathrm{f}}$.

Therefore, it is preferable to seek a linear formula in logarithmic coordinates, having the general form $\log$ $G_{\mathrm{f}} \approx \alpha_{1} \log f_{\mathrm{c}}^{\prime}+\alpha_{2} \log d_{\mathrm{a}}+\alpha_{3} \log (w / c)+\log \alpha_{4}$ or $G_{\mathrm{f}} \approx \alpha_{4}$ $f_{\mathrm{c}}^{\prime \alpha_{1}} d_{\mathrm{a}}{ }^{\alpha_{2}}(w / c)^{\alpha_{3}}$, which is also identifiable by linear regression. One advantage is that such a formula automatically precludes negative values of $G_{\mathrm{f}}$. Further refinements, though, are needed. When $d_{\mathrm{a}} \rightarrow 0$, which is the case of pure hardened cement paste, the formula should give $G_{\mathrm{f}}>0$. Therefore, $d_{\mathrm{a}}$ is replaced by $1+d_{\mathrm{a}} / \alpha_{5}$. Thus, we are led to the following prediction formula:

$G_{\mathrm{f}}=\alpha_{0}\left(\frac{f_{\mathrm{c}}^{\prime}}{\alpha_{4}}\right)^{\alpha_{1}}\left(1+\frac{d_{\mathrm{a}}}{\alpha_{5}}\right)^{\alpha_{2}}\left(\frac{w}{c}\right)^{\alpha_{3}}$.

Parameters $\alpha_{4}, \alpha_{5}$, and $\alpha_{0}$ are introduced here so as to have the dimensions of stress (MPa), length ( $\mathrm{mm})$, and fracture energy $\left(\mathrm{N} / \mathrm{m}\right.$ or $\left.\mathrm{J} / \mathrm{m}^{2}\right)$, respectively. Parameter $\alpha_{0}$ is also used to distinguish between crushed and river aggregates. Parameter $\alpha_{3}$ is expected to be negative because a decrease of $w / c$ increases strength. As for $G_{\mathrm{F}}$, a similar formula is assumed.

By analogous arguments, a similar formula is also assumed for the effective length of the fracture process zone.

Parameters $\alpha_{0}$ and $\alpha_{4}$ in Eq. (3) could of course be combined into a single parameter, assuming different values for different aggregate types. It is solely for convenience of dimensions to keep these two parameters separate. Parameters $\alpha_{0}, \alpha_{1}, \alpha_{2}, \alpha_{3}$, and $\alpha_{4}$ are obtainable by linear regression of $\log G_{f}$, but inevitably parameter $\alpha_{5}$ is involved nonlinearly.

The objective function (merit function) to be minimized by fitting the test data is chosen as

$\chi^{2}=\sum_{i=1}^{N}\left[G_{\mathrm{f}_{i}}^{\text {test }}-G_{\mathrm{f}_{i}}\right]^{2}=\min$

in which subscript $i$ labels the individual data values measured in tests in various laboratories by various investigators.
As an alternative, the objective functions $\chi^{2}=\sum_{i}\left[\left(G_{\mathrm{f}}^{\text {test }} /\right.\right.$ $\left.\left.G_{\mathrm{f}}\right)_{i}-1\right]^{2}$ and $\chi^{2}=\sum_{i}\left[\log \left(G_{\mathrm{f}}^{\text {test }} / G_{\mathrm{f}}\right)_{i}\right]^{2}$ were also considered. These functions give greater weights to smaller $G_{\mathrm{f} i}$ than does Eq. (4). Similar objective functions were assumed for $G_{\mathrm{F}}$ and $c_{\mathrm{f}}$. However, the results obtained with these alternative objective functions were worse than those obtained with Eq. (4).

Compared to $G_{\mathrm{f}}$, the values of $c_{\mathrm{f}}$ are much more uncertain. Since the objective function in the form of Eq. (4) is logically associated with the assumption of a normal distribution, the fact that the standard deviation of $c_{\mathrm{f}}$ is particularly large would mean that negative values of $c_{\mathrm{f}}$ would have a nonnegligible probability if a normal distribution of $c_{\mathrm{f}}$ were assumed. This is documented in Fig. 2, which shows the normal distributions calibrated in the sequel by the available data sets for fracture energy $\left(G_{\mathrm{f}}\right.$ ) (see Sets I, II, and III defined later) and the data set for effective length of the critical crack extension $\left(c_{\mathrm{f}}\right)$. Indeed, the values of the distribution on the negative side are seen to be negligible for $G_{\mathrm{f}}$, but not for $c_{\mathrm{f}}$. Therefore, we better assume $c_{\mathrm{f}}$ to follow a lognormal distribution and introduce formula (5):

$\log c_{\mathrm{f}}=\gamma_{0}\left(\frac{f_{\mathrm{c}}^{\prime}}{\gamma_{4}}\right)^{\gamma_{1}}\left(1+\frac{d_{\mathrm{a}}}{\gamma_{5}}\right)^{\gamma_{2}}\left(\frac{w}{c}\right)^{\gamma_{3}}$

Similar to parameter $\alpha_{i}$, parameters $\gamma_{0}, \gamma_{1}, \gamma_{2}, \gamma_{3}$, and $\gamma_{4}$ are obtainable by linear regression, while parameter $\gamma_{5}$ is involved nonlinearly. For $c_{\mathrm{f}}$, we take the objective function:

$\chi^{2}=\sum_{i=1}^{N}\left[\log \left(c_{\mathrm{f} i}^{\text {test }}\right)-\log \left(c_{\mathrm{f} i}\right)\right]^{2}=\min$,

which is logically associated with the assumption of a lognormal distribution of $c_{\mathrm{f}}$ (the "log" here is considered as the decadic logarithm).

As will be seen, the coefficient of variation of $c_{\mathrm{f}}$ can be very large. But that does not cause the prediction of $c_{\mathrm{f}}$ to be useless because what matters in practical calculations is mainly the order of magnitude of $c_{\mathrm{f}}$, and not so much the precise value. This corresponds to the fact that the size effect plot descends with an increasing slope in the logarithmic scale but with a rapidly diminishing slope in the linear scale.

Linear regression for parameters $\alpha_{1}, \alpha_{2}, \alpha_{3}, \alpha_{4}$, and $\alpha_{0}$ may seem to imply the objective function to be the sum of squared differences in the logarithms. But this turns out not to be the best assumption, as already mentioned. For this reason, and because parameter $\alpha_{5}$ cannot be identified by linear regression, the objective functions (4) and (6) are used in nonlinear optimization of all the available test data. The standard library subroutine for the Levenberg-Marquardt optimization algorithm has been employed for this purpose.

\section{Statistical analysis of fracture test data}

The prediction formulae need to be evaluated by statistical comparison to essentially all the relevant test data that 

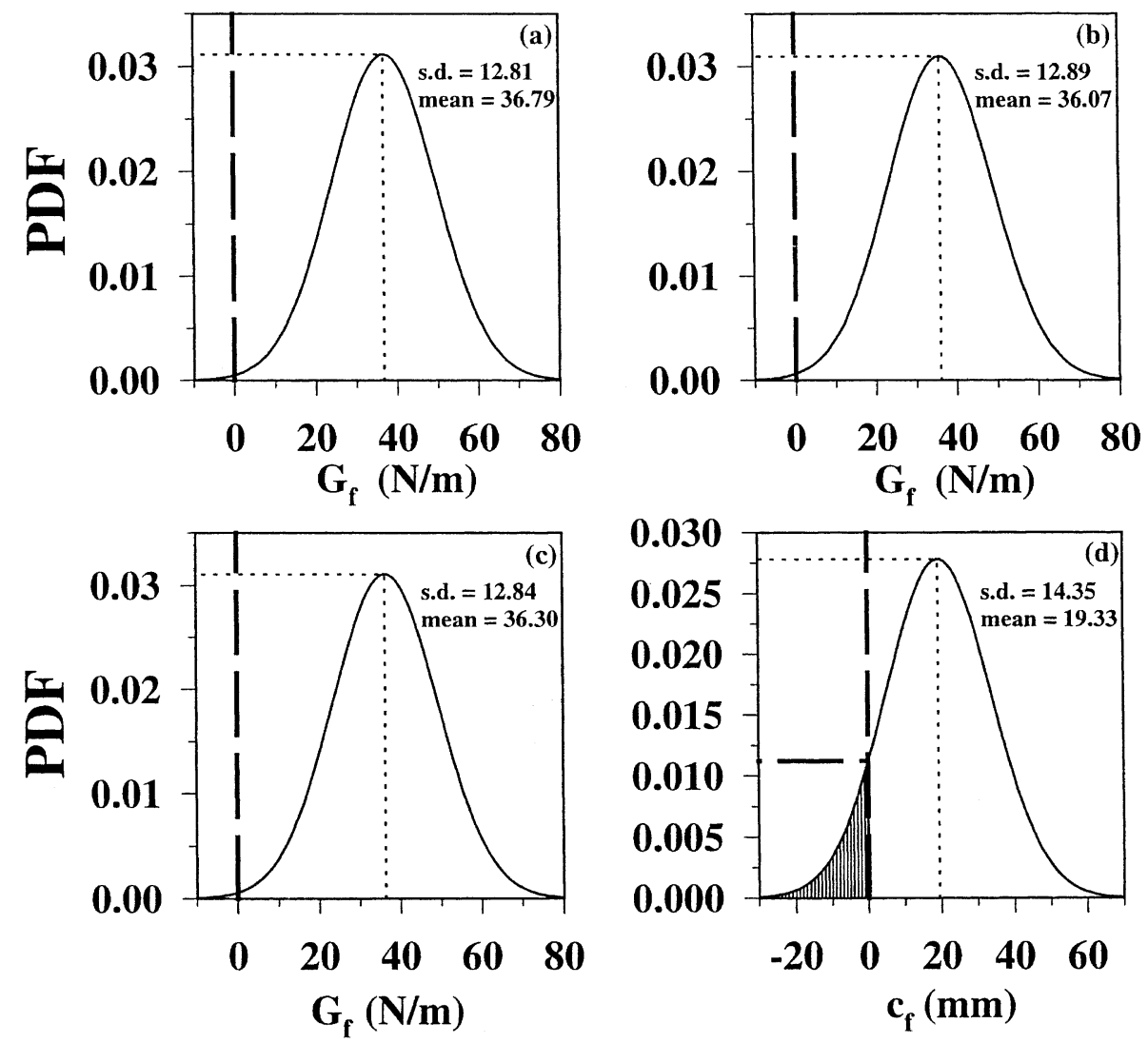

Fig. 2. Normal distributions resulting from fitting of the test data acquired, for fracture energy, from: (a) SEM, TPM, and ECM (Set I); (b) work-of-fracture (Set II); and (c) SEM, TPM, ECM, and work-of-fracture combined (Set III); and for critical effective crack extension $c_{f}$, from (d) SEM and TPM.

exist [1-93] and statistics of their errors determined. One problem with the database existing in the literature is that different investigators used different methods to determine the fracture parameters (the fact that specimens of different sizes and shapes were used is ignored because the results of a good testing procedure, presumably, should not depend on these factors, and if they do there is anyway insufficient information for compensating).

The older tests (from 1961 until about 1980) were intended for evaluation by the LEFM, which is inadequate, and therefore the results of these tests could not be used. The following four methods, representing the main testing methods, will be considered:

1. The WFM, which was proposed for concrete by Hillerborg $[44,45]$.

2. The SEM [24,79], based on size effect law [7].

3. The Jenq-Shah method based on their TPM $[50,78]$.

4. Karihaloo and Nallathambi's [54-56,66] ECM (which is not a general model but is formulated only for notched beam specimens).

Because, as already mentioned, SEM, TPM, and ECM give essentially equivalent results, and because the fracture parameters of SEM can be easily transformed to the fracture parameters of TPM and vice versa [16,23], all the test data obtained by these three methods are grouped into the first set, which comprises 77 data (Set I). The fracture toughness $\left(K_{\mathrm{c}}\right)$ measured by TPM or ECM has been transformed to SEM fracture energy $\left(G_{\mathrm{f}}\right)$ (Fig. 1) according to the wellknown relation:

$G_{\mathrm{f}}=K_{\mathrm{c}}^{2} / E^{\prime}$.

Because the critical crack-tip opening displacement $\delta_{\mathrm{CTOD}}=\left(32 G_{\mathrm{f}} c_{\mathrm{f}} / E^{\prime} \pi\right)^{1 / 2}$ (see Eq. (13)) [16,9], in which, for plane strain, $E^{\prime}=E /\left(1-\nu^{2}\right), \nu=$ Poisson ratio. The measured $\delta_{\text {CTOD }}$ values obtained by TPM were transformed to the SEM parameter $c_{\mathrm{f}}$ by relation (8):

$c_{\mathrm{f}}=\frac{\pi E^{\prime}}{32 G_{\mathrm{f}}} \delta_{\mathrm{CTOD}}^{2}$

As recently established, SEM, as well as TPM and ECM, gives the fracture energy value representing the area under the initial tangent of the softening stress-separation diagram of the cohesive crack model (or the area under the analogous stress-strain diagram of the crack band model multiplied by the crack bandwidth) (see Fig. 1). The statistical analysis is first conducted using only the data from SEM, TPM, and ECM. The value of $E^{\prime}$ needed for these calculations was reported by only a few experimenters. In the other cases, this value was estimated from the 
reported compressive strength $\left(f_{\mathrm{c}}^{\prime}\right)$ using the approximate ACI equation. Since this equation uses the cylindrical strength and some experimenters reported the cubical strength, the well-known approximate relation between the cylindrical and cubical strengths had to be used in these cases. The Poisson ratio, which slightly affects $E^{\prime}$, was taken as 0.18 unless reported. The approximation errors of these equations contribute to the coefficient of variation of the errors of $G_{\mathrm{f}}$ measured by these methods.

At first thought, one might wonder whether the parameters of TPM (Jenq-Shah) and ECM are properly considered if the fitting is done in terms of $G_{\mathrm{f}}$ and $c_{\mathrm{f}}$. However, as long as the relations (7) and (8) are accepted, fitting the values of $K_{\mathrm{c}}{ }^{2}$ in terms of the parameters of TPM and ECM must give the same results. If the fitted variable is $K_{\mathrm{c}}$ (which is a parameter of TPM), rather than $K_{\mathrm{c}}^{2}$, the results would differ because a different weighting of the data is implied, but they will not differ by much.

The fracture energy $G_{\mathrm{F}}$ determined by WFM corresponds to the area under the entire stress-separation curve, including its long tail [31] (Fig. 1). This area is much larger than $G_{\mathrm{f}}$ (see the explanation in Appendix C). Therefore, the test results obtained by WFM have been considered in the second statistical analysis as a separate set (Set II), in which $G_{\mathrm{F}}$ was transformed into $G_{\mathrm{f}}$ according to the relationship [75]:

$G_{\mathrm{f}} \approx 0.4 G_{\mathrm{F}}$.

This is, admittedly, only a crude estimate. In reality, the ratio $G_{\mathrm{f}} / G_{\mathrm{F}}$ of course depends on the shape of the softening curve [23] and is influenced by the dependence of the measured $G_{\mathrm{F}}$ values on the size and shape of the specimen, reported by many experimenters. However, no formulae and no clear trends for such influences are known, and so the constancy of the ratio $G_{\mathrm{F}} / G_{\mathrm{f}}$ is an inevitable simplifying hypothesis. An important point to note is that the assumption of a fixed ratio in Eq. (9) does not bias the scatter statistics in favor of one or another method. If one would do the symmetrical opposite-convert all the data on $G_{\mathrm{f}}$ to data on $G_{\mathrm{F}}$ and then fit the aggregate of all data in terms of $G_{\mathrm{F}}$, the resulting coefficient of variation would be exactly the same. Similar comments can be made in regard to replacing $c_{\mathrm{f}}$ by $\delta^{2}{ }_{\mathrm{CTOD}}$ as the variable used in data fitting.

The third statistical analysis deals with all the data from SEM, TPM, ECM, and WFM combined into one set (Set III), with $G_{\mathrm{F}}$ being transformed to $G_{\mathrm{f}}$ according to Eq. (9). Since 77 usable data have been found in the literature for Set I and 161 data for Set II, one has a total of 238 data for Set III. Since the $G_{\mathrm{F}}$ measurement as well as the relationship in Eq. (9) is rather uncertain, such a combined set must be expected to exhibit a large scatter, which proved to be the case.

In preliminary optimizations of the overall fit of Set III, the ratio $G_{\mathrm{f}} / G_{\mathrm{F}}$ was considered as an additional unknown. The statistical studies reported here were run for different assumed values of this ratio and the standard deviations of errors compared. It was found that indeed the value 0.4 proposed in [75] and used in Eq. (9) is approximately the optimum value.

The dependence of parameter $\alpha_{0}$ on the type of aggregate (crushed or river aggregate) has been determined by considering a sequence of values $\alpha_{0}=1,1.01,1.02, \ldots 1.50 \mathrm{~N} / \mathrm{m}$. The values that provided the best statistics were identified as:

- for river aggregates: $\quad \alpha_{0}=1 \mathrm{~N} / \mathrm{m}$;

- for crushed aggregates:

$$
\begin{aligned}
& \text { Set I: } \alpha_{0}=1.44 \mathrm{~N} / \mathrm{m} \text {, } \\
& \text { Set II: } \alpha_{0}=1.12 \mathrm{~N} / \mathrm{m} \text {, } \\
& \text { Set III: } \alpha_{0}=1.11 \mathrm{~N} / \mathrm{m} .
\end{aligned}
$$

The shape of the aggregate, unfortunately, is not reported for many of the data in the literature. When it is not, the aggregates have been automatically assumed to be smooth river aggregates, for which, by choice, $\alpha_{0}=1 \mathrm{~N} / \mathrm{m}$.

For the remaining parameters, the following optimal values have been identified by Levenberg-Marquardt optimization algorithm:

- Set I: $\alpha_{1}=0.46, \alpha_{2}=0.22, \alpha_{3}=-0.30, \alpha_{4}=0.051$, $\alpha_{5}=11.27$.

- Set II: $\alpha_{1}=0.40, \alpha_{2}=0.43, \alpha_{3}=-0.18, \alpha_{4}=0.058$, $\alpha_{5}=1.94$.

- Set III: $\alpha_{1}=0.43, \alpha_{2}=0.47, \alpha_{3}=-0.20, \alpha_{4}=0.062$, $\alpha_{5}=3.95$.

After obtaining the optimal values of all the parameters, the values of the predicted fracture energies $\left(G_{\mathrm{f}}{ }^{\text {pred }}\right)$ were computed for each data set from Eq. (3) and were compared to the corresponding values $G_{\mathrm{f}}^{\text {test }}$ measured in the test. Then the diagram of $G_{\mathrm{f}}^{\text {test }}$ versus $G_{\mathrm{f}}{ }^{\text {pred }}$ could be plotted. Such diagrams are shown for Sets I, II, and III in Fig. 3. Furthermore, the diagrams of $G_{\mathrm{f}}^{\text {test }} / G_{\mathrm{f}}{ }^{\text {pred }}$ versus $G_{\mathrm{f}}{ }^{\text {pred }}$ are shown in Fig. 3, showing that the scatter in Sets II and III is more significant. In order to facilitate comparisons, all the statistical plots for $G_{\mathrm{F}}$ presented here are plotted in terms of the scaled values $G_{\mathrm{f}}=0.4 G_{\mathrm{F}}$. This is possible since the scaling by the factor 0.4 has no effect on the coefficient of variation.

Although the Levenberg-Marquardt algorithm supplies statistical characteristics, it is preferable, and clearer for the user, to determine the statistical characteristics on the basis of the plots in Fig. 3. To this end, a linear regression is performed in the plot of $G_{\mathrm{f}}^{\text {test }}$ versus $G_{\mathrm{f}}^{\text {pred }}$ (Fig. 3), and the coefficient of correlation $r$ between $G_{\mathrm{f}}^{\text {test }}$ and $G_{\mathrm{f}}{ }^{\text {pred }}$ is calculated. Also calculated is the coefficient of variation $\omega_{G}$ of the ratio $G_{\mathrm{f}}^{\text {test }} / G_{\mathrm{f}}$ pred, which indicates the relative variation of the measured fracture energy with respect to the predicted means $G_{\mathrm{f}}^{\text {pred }}$. Calculations of this type can be repeated many times until the parameter values that give either the lowest coefficient of variation of the ratio $G_{\mathrm{f}}^{\text {test }} /$ $G_{\mathrm{f}}{ }^{\text {pred }}$ or the highest correlation coefficient $r$ are obtained. 

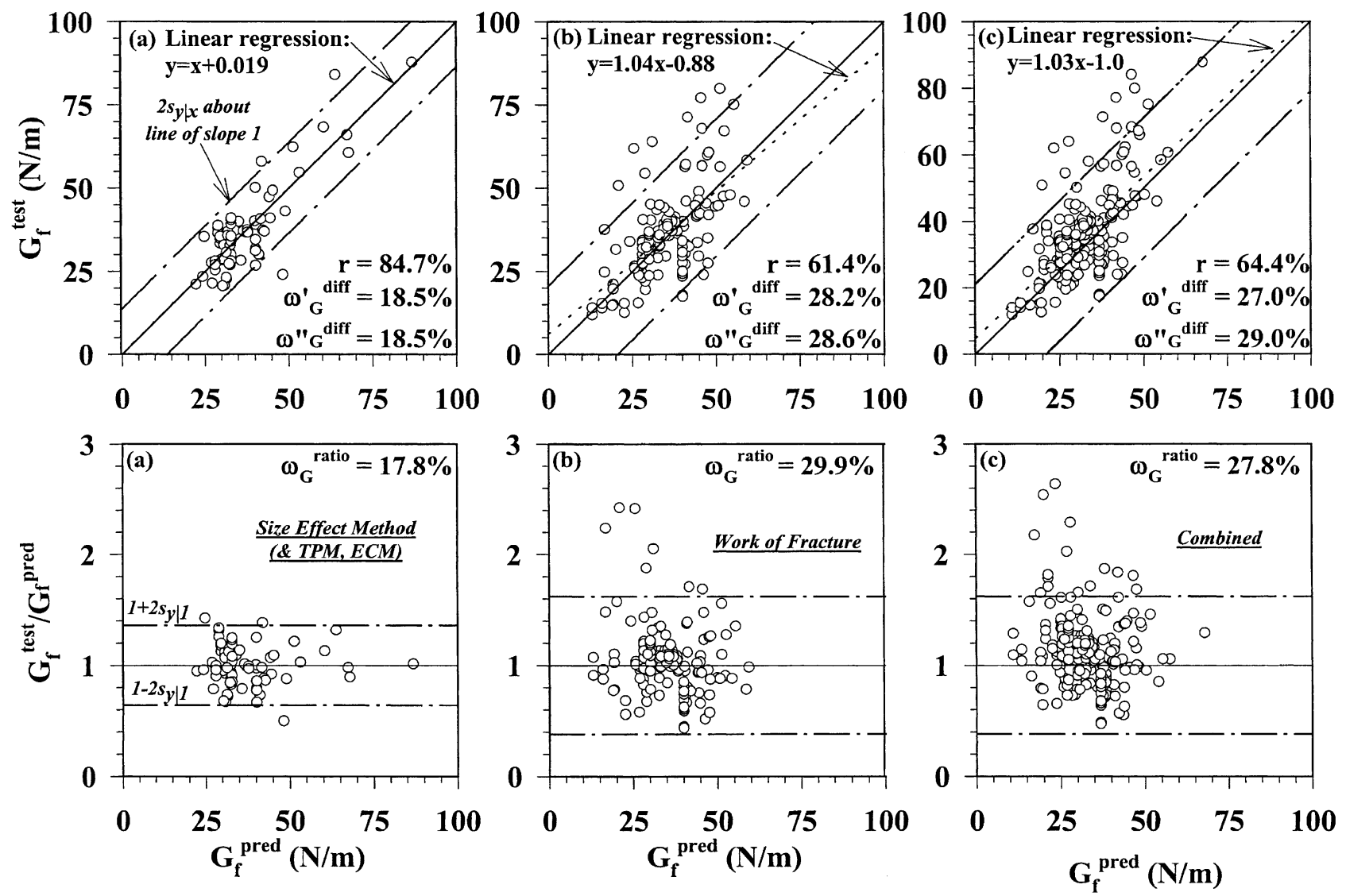

Fig. 3. Plots of measured versus predicted values of $G_{\mathrm{f}}$ or $0.4 G_{\mathrm{F}}$, obtained for (a) SEM, TPM, and ECM (Set I, 77 data); (b) work-of-fracture (Set II, 161 data); (c) SEM, TPM, ECM, and work-of-fracture combined (Set III, 238 data). Note: $s_{y \mid x}$ : standard deviation of vertical differences of data from line of slope 1; $s_{y \mid 1}$ : standard deviation of the differences of $G_{\mathrm{f}}^{\text {test }} / G_{\mathrm{f}}^{\text {pred }}$ from 1 .

A similar procedure can be followed for $c_{\mathrm{f}}^{\text {pred }}$. The plot of $c_{\mathrm{f}}^{\text {test }}$ versus predicted $c_{\mathrm{f}}{ }^{\text {pred }}$ and $c_{\mathrm{f}}^{\text {test }} / c_{\mathrm{f}}$ pred versus predicted $c_{\mathrm{f}}{ }^{\text {pred }}$ are shown in Fig. $4 \mathrm{a}$, and the plot of $\log c_{\mathrm{f}}^{\text {test }}$ versus the predicted $\log c_{\mathrm{f}}^{\text {pred }}$ is shown in Fig. $4 \mathrm{~b}$. In practical applications, the lognormal distribution should be assumed for $c_{\mathrm{f}}$; it is fully characterized by the value of the standard deviation in the plot in Fig. 4b. The coefficient of correlation $r$ between $c_{\mathrm{f}}^{\text {test }}$ and $c_{\mathrm{f}}^{\text {pred }}$, as well as the coefficient of variation $\omega_{\mathrm{C}}$ of the ratio $c_{\mathrm{f}}^{\text {test }} / c_{\mathrm{f}}^{\text {pred }}$, are also computed and shown on Fig. 4a.

Figs. 3, 5, and 6) show the diagrams of $G_{\mathrm{f}}^{\text {test }}$ versus $G_{\mathrm{f}}^{\text {pred }}$ and the regression line, which should ideally be a line of slope 1 passing through the origin. However, since the objective function used to optimize the parameters was different from the sum of squared deviation in these plots, the regression line is slightly different. The plots of $G_{\mathrm{f}}^{\text {test }}$ and of $G_{\mathrm{f}}^{\text {test }} / G_{\mathrm{f}}^{\text {pred }}$ versus $G_{\mathrm{f}}^{\text {pred }}$ also show the approximate $5 \%$ and $95 \%$ confidence limits of the vertical deviations of the data points from the line of slope 1 . The approximate $5 \%$ and $95 \%$ confidence limits for the vertical deviations from a horizontal line of ordinate 1 are marked in the diagrams of $G_{\mathrm{f}}^{\text {test }} / G_{\mathrm{f}}^{\text {pred }}$ versus $G_{\mathrm{f}}^{\text {pred }}$. These confidence limits have been estimated on the basis of the normal (Gaussian) distribution, by passing lines parallel to the regression line at vertical distances $\pm 2 s_{y \mid x}$ from that line, $s_{y \mid x}$ being the standard error of the estimate of $G_{f}^{\text {test }}$ or of $G_{\mathrm{f}}^{\text {test }} / G_{\mathrm{f}}^{\text {pred }}$.

Note that the coefficients of variation of the vertical deviations about the regression line (given in the figures) are slightly different from those about the line of slope 1 (the line of perfect prediction). The former characterizes best the statistical scatter while the latter characterizes best the quality of prediction. The values of the correlation coefficient $r$ corresponding to the regressions in these plots are also given in the figures.

Because the statistical scatter of the deviations from the proposed formulae is quite high, it ought to be taken into account in design.

\section{Discussion of statistics and comparison of fracture parameters measured by different methods}

Interesting is the comparison of the statistics between Set I (for $G_{\mathrm{f}}$ ) and Set II (for $G_{\mathrm{F}}$ ). As seen from Fig. 3, the test results for $G_{\mathrm{F}}$ with the WFM exhibit a far larger scatter and a weaker correlation - the coefficient of variation of predictions of the ratio $G_{\mathrm{f}}^{\text {test }} / G_{\mathrm{f}}^{\text {pred }}$ is $\omega_{G \mathrm{f}}=29.9 \%$, 

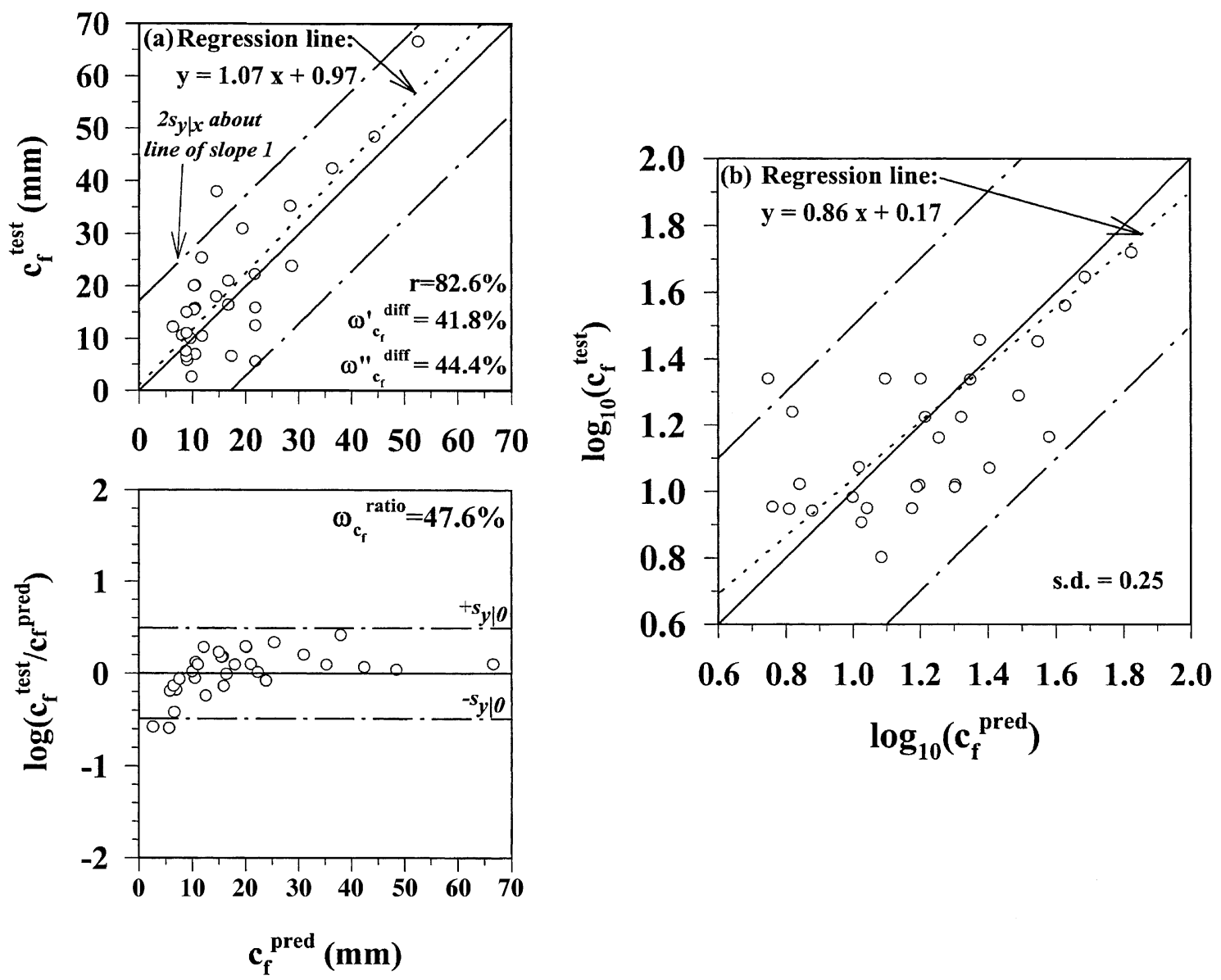

Fig. 4. Plots of measured versus predicted values of $c_{\mathrm{f}}$ (left, a) and $\log \left(c_{\mathrm{f}}\right)$ (right, b) (for SEM and TPM).

while that of the ratio $G_{\mathrm{F}}{ }^{\text {test }} / G_{\mathrm{F}}{ }^{\text {pred }}$ is $\omega_{G \mathrm{~F}}=17.8 \%$, which is 1.67 times smaller (and the correlation coefficient is $61.4 \%$ compared to $84.7 \%$ ).

Compared to the Set II results, another more favorable feature of the Set I results is that the linear regression of the plot of the tested versus predicted values gives for Set I a regression line that passes closer to the origin, and has a slope closer to 1.0 .

The coefficients of variation $\omega_{G}^{\prime}$ about the regression line and $\omega_{G}^{\prime \prime}$ about the line of slope 1 are also computed and written in Fig. 3. Their values reinforce the observation that the results obtained with the WFM exhibit a much higher scatter. Here, $\omega_{G}{ }^{\prime}$ is computed as the ratio of the standard error of the estimate about the regression line over the centroid of test data ordinates, while $\omega_{G}^{\prime \prime}$ is computed as the ratio of the standard error of the vertical deviations from the line of slope 1 to the centroid of the data ordinates.

The larger uncertainty of predicting $G_{\mathrm{F}}$ with the WFM can conceivably have two explanations: (1) The method, both the concept and the measurement, may have a higher degree of uncertainty, or (2) the prediction of the mean of $G_{\mathrm{F}}$ can be more uncertain than the prediction of the mean of $G_{\mathrm{f}}$.
At this point, it is not clear which explanation is true. It seems nevertheless likely that the first explanation is valid at least to some extent. The reason is that the initial tangent of the softening stress-separation curve, which defines $G_{f}$, can be identified from measurements with less uncertainty than the tail of this curve, which has no effect on $G_{\mathrm{f}}$ but a large effect on $G_{\mathrm{F}}$. Experience from testing suggests that the tail is highly uncertain, difficult to measure, and more strongly influenced by the specimen shape [80], size [61], and the test setup. Nevertheless, further research is needed to decide this question unambiguously.

The large errors in $G_{\mathrm{F}}$ prediction could perhaps be reduced by including some empirical factors accounting for the effects of size and shape on the $G_{\mathrm{F}}$, as revealed by some experiments. But doing that would be tantamount to admitting that $G_{\mathrm{F}}$ is not a material parameter, and thus not generally usable.

Another question that arises is the sensitivity of $G_{\mathrm{f}}$ or $c_{\mathrm{f}}$ to the various influencing parameters in the prediction formulae, particularly to $f_{\mathrm{c}}^{\prime}, d_{\mathrm{a}}$, and $w / c$. To check the sensitivity, the coefficients of correlation between each parameter and $G_{\mathrm{f}}^{\text {test }}$ were calculated for Sets I and II, and the same for $c_{\mathrm{f}}$. For Set I, the coefficient of correlation was found to be $56.5 \%$ for $f_{\mathrm{c}}^{\prime}, 20 \%$ for $d_{\mathrm{a}}$, and $-37.1 \%$ for $w / c$. 

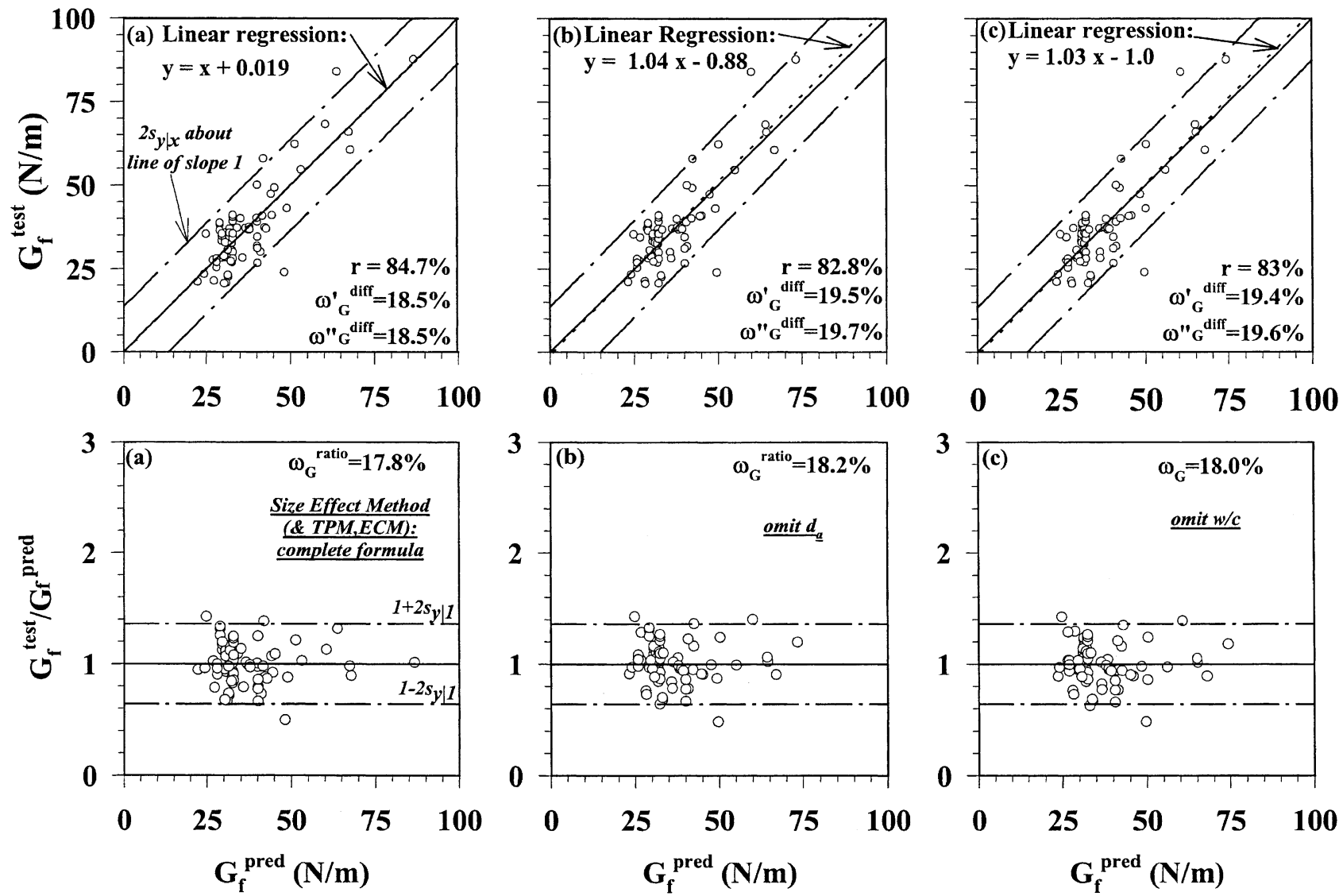

Fig. 5. Plots of measured versus predicted value of $G_{\mathrm{f}}$ (for Set I) showing the effect of omitting either $d_{\mathrm{a}}$ (plot b) or $w / c$ (plot c) from the set of parameters (case a is the plot with all the parameters, same as Fig. 3, shown for comparison).

So the strongest correlation exists for the compression strength, a smaller one for the water-cement ratio, and a still smaller one for the maximum aggregate size. For Set II, these correlation coefficients were $43.9 \%, 49.7 \%$, and $-1.4 \%$, respectively. In the case of $c_{\mathrm{f}}$, the correlation coefficients were $-10.7 \%, 73.2 \%$, and $37.7 \%$, respectively. So there is a very strong correlation between the maximum aggregate size and $c_{\mathrm{f}}$, while the correlation between the compressive strength and $c_{\mathrm{f}}$ is very weak.

It must be understood, however, that these numbers would characterize the sensitivity fully only if $f_{\mathrm{c}}^{\prime}, d_{\mathrm{a}}$, and $w / c$ were independent. In reality, $f_{\mathrm{c}}^{\prime}$ and $w / c$ are known to be strongly correlated. If parameter $f_{\mathrm{c}}^{\prime}$ were dropped, then its place would be taken by $w / c$, and the correlations would become much stronger. Such information on the sensitivity of various parameters may allow a further simplification of the formula with only a relatively small increase of the coefficients of variation or the errors.

The effect of omitting either $d_{\mathrm{a}}$ or $w / c$ from the prediction formula derived using the data obtained from SEM and other equivalent methods is seen on Fig. 5. This effect is not strong, but not negligible either. Fig. 6, on the left, compares the 161 test data with the prediction formula recommended in the CEB-FIP model code [29] to the formula calibrated with Set II (Fig. 6b). The formula proposed by the CEB-FIP model code takes into account the compressive strength and the maximum aggregate size only, whereas the formula developed in the present work also takes into account the water-cement ratio. The scatter and the coefficient of variation are higher in Fig. 6a $\left(\omega_{G}=33.3 \%\right)$, although the effect of the water-cement ratio is not very significant (causing a reduction in the coefficient of variation by $3.4 \%$ only). Nevertheless, since the formulae are already very simple, no further simplification, always accompanied by at least some loss of accuracy, is made.

To make verification of the present results possible, and to facilitate further statistical studies, Table 1 presents a list of all the test data used in the present study. This table includes essentially all the test data that currently exist in the literature. A list defining the notations used in Table 1 is found in Table 2.

It might be objected that the present study mixes the results from many different concretes. This of course increases the coefficients of variation of the errors of prediction because the present formulae, taking into account different compositions and strengths, are only crude empirical approximations. But what would be the alternative? 
Some might prefer the alternative of using in statistical evaluation the data for only one and the same concrete. But then, the available data basis would be far smaller. One can hardly expect that a data set equal to that used here could be accumulated for one and the same concrete. Even if it were, if would give statistical information valid only for that concrete, and it would be hard to infer the statistical characteristics for other concretes.

Could the mixing of data from different concretes have introduced a statistical bias in favor of $G_{\mathrm{f}}$ or $G_{\mathrm{F}}$ ? It could not. It must have significantly increased the coefficients of variation, but about equally for both.

If the coefficients of variation of the present prediction formulae seem too high, it should be noted that the errors of the best prediction formulae for creep and shrinkage of concrete have even higher coefficients of variation (which are $24 \%$ for basic creep, $23 \%$ for drying creep, and $34 \%$ for shrinkage). However, since the consequences of errors in fracture parameters affect failure predictions, while errors in creep and shrinkage do not (creep buckling excepted), the present formulae should be used for nothing more than (1) preliminary design estimates or (2) safety evaluations of structures of low fracture sensitivity.
5. Proposed formulae for mean $G_{\mathfrak{f}}, c_{\mathfrak{f}}, G_{\mathrm{F}}$, and $\delta_{\mathbf{C T O D}}$ (Eqs. (10), (11), and (12), respectively)

$$
\begin{aligned}
& G_{\mathrm{f}}=\alpha_{0}\left(\frac{f_{\mathrm{c}}^{\prime}}{0.051}\right)^{0.46}\left(1+\frac{d_{\mathrm{a}}}{11.27}\right)^{0.22}\left(\frac{w}{c}\right)^{-0.30} ; \\
& \omega_{G_{\mathrm{f}}}=17.8 \%
\end{aligned}
$$

$$
\begin{aligned}
& c_{\mathrm{f}}=\exp \left[\gamma_{0}\left(\frac{f_{\mathrm{c}}^{\prime}}{0.022}\right)^{-0.019}\left(1+\frac{d_{\mathrm{a}}}{15.05}\right)^{0.72}\left(\frac{w}{c}\right)^{0.2}\right] ; \\
& \omega_{c_{\mathrm{f}}}=47.6 \%
\end{aligned}
$$

$G_{\mathrm{f}}=2.5 \alpha_{0}\left(\frac{f_{\mathrm{c}}^{\prime}}{0.051}\right)^{0.46}\left(1+\frac{d_{\mathrm{a}}}{11.27}\right)^{0.22}\left(\frac{w}{c}\right)^{-0.30}$

$\omega_{G_{\mathrm{F}}}=29.9 \%$

where $\alpha_{0}=\gamma_{0}=1$ for rounded aggregates, while $\alpha_{0}=1.44$ and $\gamma_{0}=1.12$ for crushed or angular aggregates; $\omega_{G \mathrm{f}}$ and
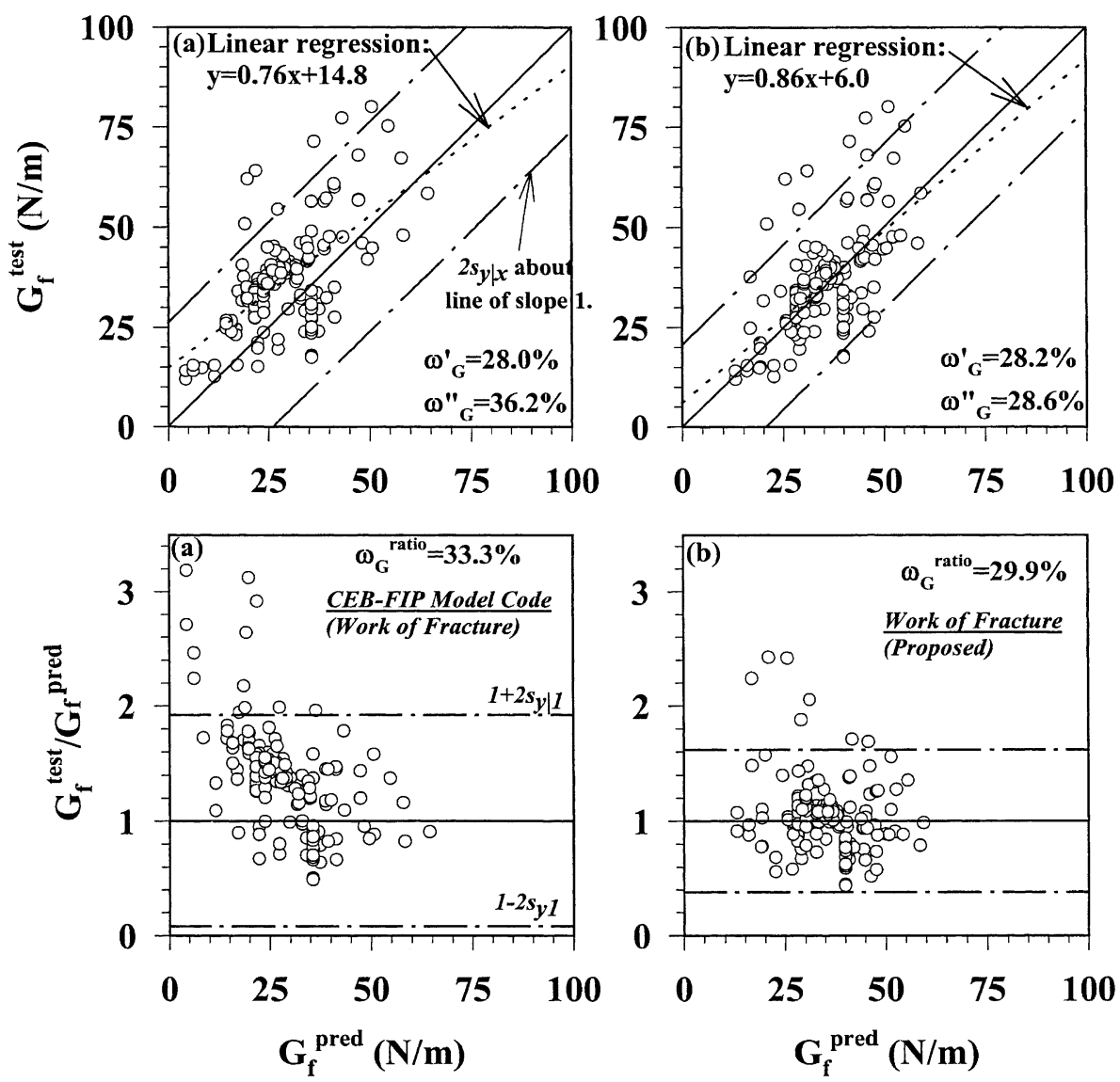

Fig. 6. Plots of measured versus predicted values of $G_{\mathrm{f}}$ or $G_{\mathrm{F}}$ : (a) CEB-FIP Model Code formulation for $G_{\mathrm{f}}$ (work-of-fracture) (Eq. (15)). (b) Proposed model calibrated with work-of-fracture data. 
Table 1

\begin{tabular}{|c|c|c|c|c|c|c|c|c|c|c|c|c|c|}
\hline References & $\begin{array}{l}\text { Test } \\
\text { type }\end{array}$ & $\begin{array}{l}\text { Test } \\
\text { age }\end{array}$ & $\begin{array}{l}f_{\mathrm{c}}^{\prime} \\
(\mathrm{MPa})\end{array}$ & $\begin{array}{l}F_{\mathrm{t}}^{\prime} \\
(\mathrm{MPa})\end{array}$ & $\begin{array}{l}E \\
\text { (GPa) }\end{array}$ & $w / c$ & $\begin{array}{l}\text { Aggregate } \\
\text { type }\end{array}$ & $\begin{array}{l}d_{\mathrm{a}} \\
(\mathrm{mm})\end{array}$ & $\begin{array}{l}K_{\mathrm{c}} \\
\left(\mathrm{MPa} \mathrm{m}^{1 / 2}\right)\end{array}$ & $\begin{array}{l}\delta_{\mathrm{CTODc}} \\
(\mathrm{mm})\end{array}$ & $\begin{array}{l}G_{\mathrm{F}} \\
(\mathrm{N} / \mathrm{m})\end{array}$ & $\begin{array}{l}G_{\mathrm{f}} \\
(\mathrm{N} / \mathrm{m})\end{array}$ & $\begin{array}{l}c_{\mathrm{f}} \\
(\mathrm{mm})\end{array}$ \\
\hline \multirow[t]{3}{*}{ [1] } & TPB & & 29 & & 32.5 & 0.53 & & 19 & 1.413 & & & & \\
\hline & TPB & & 34.3 & & 33.2 & 0.53 & & 19 & 1.759 & & & & \\
\hline & TPB & & 26.3 & & 32 & 0.53 & & 19 & 1.232 & & & & \\
\hline \multirow[t]{2}{*}{ [2] } & CNR & 28 & & & & 0.37 & & & 0.56 & & 101 & & \\
\hline & CNR & 28 & & & & 0.37 & & & 0.558 & & 72 & & \\
\hline \multirow[t]{3}{*}{ [3] } & $\mathrm{CC}$ & & 52.5 & & & 0.5 & LI & 10 & 0.61 & & & & \\
\hline & $\mathrm{CC}$ & & 52.5 & & & 0.5 & LI & 10 & 0.68 & & & & \\
\hline & $\mathrm{CC}$ & & 52.5 & & & 0.5 & LI & 10 & 0.74 & & & & \\
\hline \multirow[t]{17}{*}{ [4] } & $\mathrm{CC}$ & 28 & 51.5 & & & 0.5 & LI & 10 & 0.543 & & & & \\
\hline & $\mathrm{CC}$ & 28 & 51.5 & & & 0.5 & LI & 10 & 0.458 & & & & \\
\hline & $\mathrm{CC}$ & 28 & 51.5 & & & 0.5 & LI & 10 & 0.467 & & & & \\
\hline & $\mathrm{CC}$ & 28 & 51.5 & & & 0.5 & LI & 10 & 0.462 & & & & \\
\hline & $\mathrm{CC}$ & 28 & 51.5 & & & 0.5 & LI & 10 & 0.526 & & & & \\
\hline & $\mathrm{CC}$ & 28 & 51.5 & & & 0.5 & LI & 10 & 0.532 & & & & \\
\hline & $\mathrm{CC}$ & 28 & 51.5 & & & 0.5 & LI & 10 & 0.52 & & & & \\
\hline & $\mathrm{CC}$ & 28 & 51.5 & & & 0.5 & LI & 10 & 0.452 & & & & \\
\hline & $\mathrm{CC}$ & 28 & 51.5 & & & 0.5 & LI & 10 & 0.514 & & & & \\
\hline & $\mathrm{CC}$ & 28 & 51.5 & & & 0.5 & LI & 10 & 0.54 & & & & \\
\hline & $\mathrm{CC}$ & 28 & 51.5 & & & 0.5 & LI & 10 & 0.52 & & & & \\
\hline & $\mathrm{CC}$ & 28 & 51.5 & & & 0.5 & LI & 10 & 0.514 & & & & \\
\hline & $\mathrm{CC}$ & 28 & 51.5 & & & 0.5 & LI & 10 & 0.525 & & & & \\
\hline & $\mathrm{CC}$ & 28 & 51.5 & & & 0.5 & LI & 10 & 0.57 & & & & \\
\hline & $\mathrm{CC}$ & 28 & 51.5 & & & 0.5 & LI & 10 & 0.56 & & & & \\
\hline & $\mathrm{CC}$ & 28 & 51.5 & & & 0.5 & LI & 10 & 0.583 & & & & \\
\hline & $\mathrm{CC}$ & 28 & 51.5 & & & 0.5 & LI & 10 & 0.547 & & & & \\
\hline [5] & ТРВ & & & & 36.8 & 0.53 & $\mathrm{CM}$ & 3.15 & 0.8935 & 0.0042 & & & \\
\hline \multirow[t]{6}{*}{ [22] } & ТРВ & 28 & 34.1 & 2.91 & 27.7 & 0.6 & $\mathrm{CL}$ & 12.7 & & & & 40.1 & \\
\hline & NT & 28 & 29.1 & 2.69 & 25.5 & 0.6 & $\mathrm{CL}$ & 12.7 & & & & 36.8 & \\
\hline & $\mathrm{EC}$ & 28 & 37.4 & 3.05 & 29 & 0.6 & $\mathrm{CL}$ & 12.7 & & & & 40.8 & \\
\hline & TPB & 28 & 48.4 & 3.47 & 32.9 & 0.5 & SRS & 4.83 & & & & 22.6 & \\
\hline & NT & 28 & 46.4 & 3.39 & 32.2 & 0.5 & SRS & 4.83 & & & & 20.7 & \\
\hline & EC & 28 & 48.1 & 3.45 & 32.8 & 0.5 & SRS & 4.83 & & & & 23.1 & \\
\hline \multirow[t]{2}{*}{ [25] } & FPB & & 12.6 & 2.16 & 18.6 & 0.5 & & 9.52 & & & & 36.3 & \\
\hline & FPB & & 16.3 & 2.45 & 21.6 & 0.6 & & 19.1 & & & & 49 & \\
\hline \multirow[t]{3}{*}{ [26] } & ТРВ & & 60.7 & & 33.5 & 0.44 & & 6 & 1.141 & 0.0145 & & & \\
\hline & ТРВ & & 45.5 & & 31 & 0.52 & & 12.7 & 1.475 & 0.022 & & & \\
\hline & TPB & & 43.4 & & 31 & 0.52 & & 12.7 & 1.53 & 0.0169 & & & \\
\hline \multirow[t]{2}{*}{ [27] } & ТРВ & 28 & 33.9 & 2.92 & 22.3 & 0.3 & CBA & 12.7 & 0.91 & & & 37.2 & 25.4 \\
\hline & ТPB & 28 & 30.1 & 3.16 & 19.7 & 0.3 & SA & 12.7 & 0.82 & & & 34.4 & 10.4 \\
\hline \multirow[t]{4}{*}{ [28] } & ТPB & 56 & 67.2 & 4.18 & 26.3 & 0.43 & CSS & 12.7 & & & & 68.3 & \\
\hline & TPB & 56 & 50.7 & 3.58 & 22.9 & 0.43 & NRS & - & & & & 22.5 & \\
\hline & ТРВ & 56 & 75.2 & 3.2 & 19.8 & 0.43 & - & - & & & & 3.48 & \\
\hline & ТРB & 56 & 54.4 & 1.39 & 15.2 & 0.43 & - & - & & & & 3.4 & \\
\hline \multirow[t]{2}{*}[30,73]{} & ТРВ & & 36.2 & & 24 & 0.58 & & 20 & 1.031 & & & & \\
\hline & TPB & & 38.3 & & 34.1 & 0.58 & & 16 & 1.12 & & & & \\
\hline \multirow[t]{11}{*}{ [32] } & ТРВ & & 49.5 & 3.55 & 28.4 & 0.48 & & & & & 58 & & \\
\hline & ТРB & & 45.9 & 3.11 & 38.4 & 0.48 & RGRA & 10 & & & 74 & & \\
\hline & TPB & & 46.6 & 3.15 & 38.7 & 0.48 & RGRA & 12.5 & & & 91 & & \\
\hline & ТРВ & & 43.5 & 2.62 & 39.8 & 0.48 & RGRA & 20 & & & 84 & & \\
\hline & ТPB & & 47.4 & 3.11 & 38.6 & 0.48 & RGRA & 12.5 & & & 93 & & \\
\hline & ТРВ & & 44.3 & 2.91 & 36.6 & 0.48 & RGRA & 20 & & & 74 & & \\
\hline & ТPB & & 48.8 & 3.48 & 38.3 & 0.48 & CGRA & 10 & & & 100 & & \\
\hline & ТРВ & & 52.4 & 3.46 & 38.8 & 0.48 & CGRA & 12.5 & & & 116 & & \\
\hline & ТРВ & & 46.6 & 2.98 & 39.6 & 0.48 & CGRA & 20 & & & 141 & & \\
\hline & ТРB & & 53.5 & 3.59 & 38.9 & 0.48 & CGRA & 12.5 & & & 106 & & \\
\hline & ТРВ & & 48.9 & 3.23 & 38.6 & 0.48 & CGRA & 20 & & & 119 & & \\
\hline [33] & & & 24.8 & 3.1 & 20.7 & 0.7 & & 20 & & & & 131 & \\
\hline & & & 23.7 & 3.03 & 20.7 & 0.7 & & 20 & & & & 112 & \\
\hline & & & & 4.76 & 15.2 & & & 1.19 & & & & 31.9 & \\
\hline [34] & ТРВ & & 55.5 & & 29.8 & 0.48 & & 10 & 1.023 & & & & \\
\hline [35] & ТPB & 14 & 85 & & 37.6 & 0.35 & GRA & 9.5 & 0.949 & & & 24 & 2.6 \\
\hline & ТРВ & 14 & 32.5 & & 27 & 0.6 & GRA & 13 & 0.759 & & & 21.4 & 6.6 \\
\hline
\end{tabular}


Table 1 (continued)

\begin{tabular}{|c|c|c|c|c|c|c|c|c|c|c|c|c|c|}
\hline References & $\begin{array}{l}\text { Test } \\
\text { type }\end{array}$ & $\begin{array}{l}\text { Test } \\
\text { age }\end{array}$ & $\begin{array}{l}f_{\mathrm{c}}^{\prime} \\
(\mathrm{MPa})\end{array}$ & $\begin{array}{l}F_{\mathrm{t}}^{\prime} \\
(\mathrm{MPa})\end{array}$ & $\begin{array}{l}E \\
(\mathrm{GPa})\end{array}$ & $w / c$ & $\begin{array}{l}\text { Aggregate } \\
\text { type }\end{array}$ & $\begin{array}{l}d_{\mathrm{a}} \\
(\mathrm{mm})\end{array}$ & $\begin{array}{l}K_{\mathrm{c}} \\
\left(\mathrm{MPa} \mathrm{m}{ }^{1 / 2}\right)\end{array}$ & $\begin{array}{l}\delta_{\text {CTODc }} \\
(\mathrm{mm})\end{array}$ & $\begin{array}{l}G_{\mathrm{F}} \\
(\mathrm{N} / \mathrm{m})\end{array}$ & $\begin{array}{l}G_{\mathrm{f}} \\
(\mathrm{N} / \mathrm{m})\end{array}$ & $\begin{array}{l}c_{\mathrm{f}} \\
(\mathrm{mm})\end{array}$ \\
\hline \multirow[t]{4}{*}{ [36] } & TPB & 4 & 64.3 & & 32.7 & 0.3 & $\mathrm{CB}$ & 12 & 2.135 & & & 139 & 92 \\
\hline & TPB & 10 & 67.5 & & 35.5 & 0.3 & $\mathrm{CB}$ & 12 & 2.147 & & & 130 & 80 \\
\hline & TPB & 31 & 60.6 & & 36.8 & 0.3 & $\mathrm{CB}$ & 12 & 1.758 & & & 84.1 & 38 \\
\hline & TPB & 231 & 68.1 & & 38.3 & 0.3 & $\mathrm{CB}$ & 12 & 1.591 & & & 66 & 18 \\
\hline \multirow[t]{10}{*}[37]{} & TPB & & 79.3 & 7 & 39.1 & 0.3 & - & & & & 75 & & \\
\hline & TPB & & 107 & 6.2 & 58.2 & 0.28 & $\mathrm{BA}$ & & & & 205 & & \\
\hline & TPB & & 63.5 & 4.9 & 38.2 & 0.3 & LI & & & & 180 & & \\
\hline & TPB & & 86.6 & 5.1 & 41.4 & 0.3 & GR & & & & 195 & & \\
\hline & TPB & & 78.7 & 4.3 & 40.8 & 0.3 & GR & & & & 185 & & \\
\hline & TPB & & 70.8 & 4.1 & 40 & 0.4 & GR & & & & 175 & & \\
\hline & TPB & & 22.7 & 2.3 & 28.8 & 0.75 & GR & & & & 135 & & \\
\hline & TPB & & 68.2 & 4.7 & 56.2 & 0.3 & GRA & & & & 150 & & \\
\hline & TPB & & 72.2 & 5.2 & 48.3 & 0.3 & GRA & & & & 170 & & \\
\hline & TPB & & 77.6 & 5.4 & 48.4 & 0.3 & CGRA & & & & 180 & & \\
\hline \multirow[t]{5}{*}{ [38] } & TPB & $21^{(+)}$ & & 6.52 & & 0.5 & FGG & 1 & 0.17 & & & & \\
\hline & TPB & $21^{(+)}$ & & 6.27 & & 0.5 & FGG & 1 & 0.187 & & & & \\
\hline & ТPB & $21^{(+)}$ & & 4.98 & & 0.5 & FGG & 16 & 0.165 & & & & \\
\hline & TPB & $21^{(+)}$ & & 5.6 & & 0.5 & FGG & 9.5 & 0.199 & & & & \\
\hline & TPB & $21^{(+)}$ & & 3.9 & & 0.5 & $\mathrm{EC}$ & 16 & 0.87 & & & & \\
\hline \multirow[t]{30}{*}{ [42] } & ТPB & & 129 & 10.3 & 51 & 0.3 & DB & 16 & & & 191 & & \\
\hline & TPB & & 120 & 9 & 39 & 0.3 & GN & 16 & & & 146 & & \\
\hline & TPB & & 114 & 9 & 42 & 0.3 & GF & 16 & & & 163 & & \\
\hline & TPB & & 121 & 8 & 41 & 0.3 & GM & 16 & & & 164 & & \\
\hline & TPB & & 126 & 9.5 & 41 & 0.3 & QS & 16 & & & 170 & & \\
\hline & TPB & & 124 & & 41 & 0.3 & Q & 16 & & & 147 & & \\
\hline & TPB & & 84 & 8 & 44 & 0.4 & DB & 16 & & & 199 & & \\
\hline & ТPB & & 86 & 6.1 & 34 & 0.4 & GN & 16 & & & 144 & & \\
\hline & TPB & & 82 & 7.7 & 37 & 0.4 & GF & 16 & & & 163 & & \\
\hline & TPB & & 93 & 7.6 & 36 & 0.4 & GM & 16 & & & 170 & & \\
\hline & TPB & & 93 & 7.2 & 36 & 0.4 & QS & 16 & & & 201 & & \\
\hline & TPB & & 90 & & 36 & 0.4 & Q & 16 & & & 129 & & \\
\hline & ТPB & & 55 & 5.4 & 38 & 0.55 & $\mathrm{DB}$ & 16 & & & 133 & & \\
\hline & TPB & & 55 & 7 & 29 & 0.55 & GN & 16 & & & 128 & & \\
\hline & TPB & & 58 & 6.3 & 33 & 0.55 & GF & 16 & & & 193 & & \\
\hline & TPB & & 57 & 7 & 32 & 0.55 & GM & 16 & & & 130 & & \\
\hline & TPB & & 57 & 6.4 & 31 & 0.55 & QS & 16 & & & 152 & & \\
\hline & TPB & & 56 & & 32 & 0.55 & Q & 16 & & & 128 & & \\
\hline & TPB & & 126 & 10.5 & 49 & 0.3 & $\mathrm{DB}$ & 16 & & & 161 & & \\
\hline & ТPB & & 131 & 10.6 & 40 & 0.3 & GN & 16 & & & 139 & & \\
\hline & TPB & & 121 & 10.8 & 42 & 0.3 & GF & 16 & & & 192 & & \\
\hline & ТPB & & 129 & 10.8 & 42 & 0.3 & GM & 16 & & & 174 & & \\
\hline & TPB & & 135 & 10.2 & 42 & 0.3 & QS & 16 & & & 160 & & \\
\hline & ТPB & & 128 & & 42 & 0.3 & Q & 16 & & & 176 & & \\
\hline & TPB & & 104 & 7.8 & 45 & 0.4 & DB & 16 & & & 161 & & \\
\hline & TPB & & 104 & 7.2 & 33 & 0.4 & GN & 16 & & & 154 & & \\
\hline & TPB & & 102 & 7.9 & 38 & 0.4 & GF & 16 & & & 144 & & \\
\hline & TPB & & 96 & 7.9 & 37 & 0.4 & GM & 16 & & & 145 & & \\
\hline & TPB & & 104 & 8.1 & 35 & 0.4 & QS & 16 & & & 154 & & \\
\hline & TPB & & 101 & & 38 & 0.4 & Q & 16 & & & 163 & & \\
\hline \multirow[t]{3}{*}{ [43] } & FT & 7 & & & & 0.4 & QS & 3 & 0.237 & & & & \\
\hline & FT & 7 & & & & 0.4 & QS & 3 & 0.111 & & & & \\
\hline & FT & 7 & & & & 0.4 & GQS & 3 & 0 & & & & \\
\hline$[45]$ & \multicolumn{13}{|c|}{ reported test data from labs } \\
\hline \multirow[t]{2}{*}{ BAM } & TPB & 38 & & & & & & 16 & & & 93 & & \\
\hline & TPB & 37 & & & & & & 16 & & & 113 & & \\
\hline \multirow[t]{5}{*}{ ENEL } & TPB & 28 & & & & 0.48 & & 20 & & & 94 & & \\
\hline & TPB & 28 & & & & 0.48 & & 20 & & & 88 & & \\
\hline & TPB & 28 & & & & 0.47 & & 10 & & & 65 & & \\
\hline & TPB & 28 & & & & 0.47 & & 10 & & & 69 & & \\
\hline & TPB & 28 & & & & 0.47 & & 10 & & & 70 & & \\
\hline
\end{tabular}

(continued on next page) 
Table 1 (continued)

\begin{tabular}{|c|c|c|c|c|c|c|c|c|c|c|c|c|c|}
\hline References & $\begin{array}{l}\text { Test } \\
\text { type }\end{array}$ & $\begin{array}{l}\text { Test } \\
\text { age }\end{array}$ & $\begin{array}{l}f_{\mathrm{c}}^{\prime} \\
(\mathrm{MPa})\end{array}$ & $\begin{array}{l}F_{\mathrm{t}}^{\prime} \\
(\mathrm{MPa})\end{array}$ & $\begin{array}{l}E \\
\text { (GPa) }\end{array}$ & $w / c$ & $\begin{array}{l}\text { Aggregate } \\
\text { type }\end{array}$ & $\begin{array}{l}d_{\mathrm{a}} \\
(\mathrm{mm})\end{array}$ & $\begin{array}{l}K_{\mathrm{c}} \\
\left(\mathrm{MPa} \mathrm{m}^{1 / 2}\right)\end{array}$ & $\begin{array}{l}\delta_{\mathrm{CTODc}} \\
(\mathrm{mm})\end{array}$ & $\begin{array}{l}G_{\mathrm{F}} \\
(\mathrm{N} / \mathrm{m})\end{array}$ & $\begin{array}{l}G_{\mathrm{f}} \\
(\mathrm{N} / \mathrm{m})\end{array}$ & $\begin{array}{l}c_{\mathrm{f}} \\
(\mathrm{mm})\end{array}$ \\
\hline \multirow[t]{9}{*}{ EPFL } & ТPB & 7 & & & & 0.58 & & 30 & & & 87 & & \\
\hline & ТРB & 7 & & & & 0.58 & & 30 & & & 110 & & \\
\hline & ТPB & 28 & & & & 0.58 & & 30 & & & 150 & & \\
\hline & ТРВ & 3 & & & & 0.45 & & 30 & & & 170 & & \\
\hline & TPB & 7 & & & & 0.45 & & 30 & & & 210 & & \\
\hline & ТРB & 28 & & & & 0.45 & & 30 & & & 250 & & \\
\hline & ТPB & 28 & & & & 0.45 & & 30 & & & 320 & & \\
\hline & ТРB & 28 & & & & 0.45 & & 30 & & & 270 & & \\
\hline & TPB & 28 & & & & 0.45 & & 30 & & & 270 & & \\
\hline ETH & ТPB & 28 & & & & 0.5 & & 16 & & & 141 & & \\
\hline \multirow[t]{10}{*}{ ISM. } & ТРB & 700 & & & & & & 25 & & & 187 & & \\
\hline & TPB & 700 & & & & & & 25 & & & 192 & & \\
\hline & TPB & 700 & & & & & & 25 & & & 147 & & \\
\hline & TPB & 700 & & & & & & 25 & & & 223 & & \\
\hline & ТPB & 700 & & & & & & 25 & & & 324 & & \\
\hline & ТРВ & 700 & & & & & & 25 & & & 310 & & \\
\hline & ТРB & 700 & & & & & & 120 & & & 373 & & \\
\hline & TPB & 700 & & & & & & 120 & & & 467 & & \\
\hline & ТРВ & 700 & & & & & & 120 & & & 442 & & \\
\hline & ТРВ & 700 & & & & & & 120 & & & 448 & & \\
\hline \multirow[t]{2}{*}{ MPA } & TPB & 7 & & & & 0.4 & & 16 & & & 175 & & \\
\hline & ТРВ & 28 & & & & 0.4 & & 16 & & & 161 & & \\
\hline $\mathrm{TU}$ & TPB & 28 & & & & 0.6 & & 25 & & & 92 & & \\
\hline UP & ТРB & 28 & & & & 0.58 & & 20 & & & 124 & & \\
\hline \multirow[t]{3}{*}{$\mathrm{UBC}$} & ТPB & 36 & & & & 0.38 & & 13 & & & 82 & & \\
\hline & TPB & 36 & & & & 0.38 & & 13 & & & 83 & & \\
\hline & TPB & 36 & & & & 0.38 & & 13 & & & 115 & & \\
\hline \multirow[t]{3}{*}{ BAM } & ТРВ & 100 & & 3.02 & 33.5 & 0.59 & & 16 & & & 179 & & \\
\hline & ТРВ & 100 & & 3.02 & 33.5 & 0.59 & & 16 & & & 173 & & \\
\hline & ТPB & 100 & & 3.02 & 33.5 & 0.59 & & 16 & & & 184 & & \\
\hline \multirow[t]{12}{*}{ Bol. } & TPB & 100 & & 2.1 & 24.6 & 0.5 & & 13 & & & 113 & & \\
\hline & ТPB & 100 & & 2.1 & 24.6 & 0.5 & & 13 & & & 133 & & \\
\hline & ТРВ & 100 & & 2.1 & 24.6 & 0.5 & & 13 & & & 113 & & \\
\hline & ТPB & 100 & & 2.1 & 24.6 & 0.5 & & 13 & & & 156 & & \\
\hline & ТPB & 100 & & 2.1 & 24.6 & 0.5 & & 13 & & & 176 & & \\
\hline & TPB & 100 & & 2.1 & 24.6 & 0.5 & & 13 & & & 170 & & \\
\hline & ТРВ & 100 & & 2.1 & 24.6 & 0.5 & & 13 & & & 174 & & \\
\hline & ТРВ & 100 & & 2.1 & 24.6 & 0.5 & & 13 & & & 202 & & \\
\hline & TPB & 100 & & 2.1 & 24.6 & 0.5 & & 13 & & & 164 & & \\
\hline & TPB & 100 & & 2.1 & 24.6 & 0.5 & & 13 & & & 170 & & \\
\hline & ТРВ & 100 & & 2.1 & 24.6 & 0.5 & & 13 & & & 178 & & \\
\hline & ТPB & 100 & & 2.1 & 24.6 & 0.5 & & 13 & & & 170 & & \\
\hline \multirow[t]{9}{*}{ EPFL } & ТPB & 7 & & 3.14 & 29.6 & 0.45 & & 30 & & & 112 & & \\
\hline & ТPB & 7 & & 2.43 & 24.7 & 0.58 & & 30 & & & 81 & & \\
\hline & TPB & 7 & & 3.32 & 22.4 & 0.5 & & 8 & & & 85 & & \\
\hline & ТPB & 7 & & 3.04 & 20.4 & 0.5 & & 3 & & & 62 & & \\
\hline & ТPB & 7 & & 3.55 & 24.4 & 0.4 & & 3 & & & 79 & & \\
\hline & TPB & 7 & & 4.1 & 26.5 & 0.4 & & 8 & & & 78 & & \\
\hline & TPB & 34 & & 3.81 & 29.1 & 0.58 & & 30 & & & 105 & & \\
\hline & TPB & 33 & & 4.27 & 32.7 & 0.48 & & 30 & & & 120 & & \\
\hline & ТPB & 30 & & 4.41 & 35.1 & 0.4 & & 30 & & & 146 & & \\
\hline \multirow[t]{6}{*}{ La Pl. } & TPB & 30 & & 2.96 & 33.9 & 0.48 & & 9.5 & & & 99 & & \\
\hline & TPB & 30 & & 2.34 & 31 & 0.58 & & 9.5 & & & 109 & & \\
\hline & ТPB & 30 & & 1.93 & 29.9 & 0.68 & & 9.5 & & & 101 & & \\
\hline & ТРВ & 30 & & 3.79 & 42.2 & 0.48 & & 19 & & & 188 & & \\
\hline & ТРB & 30 & & 2.45 & 39.9 & 0.58 & & 19 & & & 200 & & \\
\hline & TPB & 30 & & 2.27 & 35.7 & 0.68 & & 19 & & & 193 & & \\
\hline \multirow[t]{2}{*}{ MPA } & TPB & 16 & & 3.37 & 36.7 & 0.4 & & 16 & & & 152 & & \\
\hline & TPB & 32 & & 2.34 & 30.4 & 0.48 & & 32 & & & 168 & & \\
\hline
\end{tabular}


Table 1 (continued)

\begin{tabular}{|c|c|c|c|c|c|c|c|c|c|c|c|c|c|}
\hline References & $\begin{array}{l}\text { Test } \\
\text { type }\end{array}$ & $\begin{array}{l}\text { Test } \\
\text { age }\end{array}$ & $\begin{array}{l}f_{\mathrm{c}}^{\prime} \\
(\mathrm{MPa})\end{array}$ & $\begin{array}{l}F_{\mathrm{t}}^{\prime} \\
(\mathrm{MPa})\end{array}$ & $\begin{array}{l}E \\
(\mathrm{GPa})\end{array}$ & $w / c$ & $\begin{array}{l}\text { Aggregate } \\
\text { type }\end{array}$ & $\begin{array}{l}d_{\mathrm{a}} \\
(\mathrm{mm})\end{array}$ & $\begin{array}{l}K_{\mathrm{c}} \\
\left(\mathrm{MPa} \mathrm{m}{ }^{1 / 2}\right)\end{array}$ & $\begin{array}{l}\delta_{\text {CTODc }} \\
(\mathrm{mm})\end{array}$ & $\begin{array}{l}G_{\mathrm{F}} \\
(\mathrm{N} / \mathrm{m})\end{array}$ & $\begin{array}{l}G_{\mathrm{f}} \\
(\mathrm{N} / \mathrm{m})\end{array}$ & $\begin{array}{l}c_{\mathrm{f}} \\
(\mathrm{mm})\end{array}$ \\
\hline \multirow[t]{5}{*}{$\mathrm{TH}$} & TPB & 8 & & 2.9 & 30 & 0.5 & & 8 & & & 113 & & \\
\hline & TPB & 8 & & 4 & 40 & 0.34 & & 8 & & & 143 & & \\
\hline & TPB & 1 & & 4.19 & 25 & 0.35 & & 1 & & & 94 & & \\
\hline & ТPB & 3 & & 6.26 & 25 & 0.35 & & 3 & & & 127 & & \\
\hline & TPB & 6 & & 6.08 & 25 & 0.35 & & 6 & & & 155 & & \\
\hline $\mathrm{TU}$ & TPB & 25 & & 4.03 & 26.3 & 0.4 & & 25 & & & 112 & & \\
\hline \multirow[t]{9}{*}{ BAM } & TPB & 28 & & & & 0.63 & & 16 & & & 91 & & \\
\hline & TPB & 28 & & & & 0.63 & & 16 & & & 98 & & \\
\hline & TPB & 28 & & & & 0.63 & & 16 & & & 118 & & \\
\hline & TPB & 28 & & & & 0.45 & & 16 & & & 114 & & \\
\hline & TPB & 28 & & & & 0.45 & & 16 & & & 112 & & \\
\hline & TPB & 28 & & & & 0.45 & & 16 & & & 114 & & \\
\hline & TPB & 28 & & & & 0.42 & & 16 & & & 113 & & \\
\hline & TPB & 28 & & & & 0.42 & & 16 & & & 144 & & \\
\hline & TPB & 28 & & & & 0.42 & & 16 & & & 135 & & \\
\hline \multirow[t]{8}{*}{ ENEL } & TPB & 28 & & & & 0.47 & & 10 & & & 65 & & \\
\hline & TPB & 28 & & & & 0.47 & & 10 & & & 58 & & \\
\hline & TPB & 28 & & & & 0.47 & & 10 & & & 66 & & \\
\hline & TPB & 28 & & & & 0.47 & & 10 & & & 70 & & \\
\hline & TPB & 28 & & & & 0.48 & & 20 & & & 90 & & \\
\hline & TPB & 28 & & & & 0.48 & & 20 & & & 86 & & \\
\hline & TPB & 28 & & & & 0.48 & & 20 & & & 89 & & \\
\hline & ТPB & 28 & & & & 0.48 & & 20 & & & 99 & & \\
\hline \multirow[t]{6}{*}{ EPFL } & TPB & 34 & & & & 0.58 & & 30 & & & 100 & & \\
\hline & TPB & 34 & & & & 0.58 & & 30 & & & 121 & & \\
\hline & ТРВ & 34 & & & & 0.58 & & 30 & & & 163 & & \\
\hline & TPB & 31 & & & & 0.4 & & 30 & & & 130 & & \\
\hline & TPB & 31 & & & & 0.4 & & 30 & & & 167 & & \\
\hline & TPB & 31 & & & & 0.4 & & 30 & & & 234 & & \\
\hline \multirow[t]{9}{*}{ Italc. } & TPB & 30 & & & & 0.48 & & 20 & & & 77 & & \\
\hline & TPB & 30 & & & & 0.48 & & 20 & & & 105 & & \\
\hline & ТPB & 30 & & & & 0.48 & & 20 & & & 94 & & \\
\hline & ТPB & 30 & & & & 0.35 & & 20 & & & 102 & & \\
\hline & TPB & 30 & & & & 0.35 & & 20 & & & 160 & & \\
\hline & TPB & 30 & & & & 0.35 & & 20 & & & 150 & & \\
\hline & TPB & 30 & & & & 0.33 & & 20 & & & 174 & & \\
\hline & TPB & 30 & & & & 0.33 & & 20 & & & 218 & & \\
\hline & TPB & 30 & & & & 0.33 & & 20 & & & 221 & & \\
\hline \multirow[t]{6}{*}{ La Pl. } & TPB & 30 & & & & 0.48 & & 9.5 & & & 113 & & \\
\hline & ТPB & 30 & & & & 0.47 & & 9.5 & & & 151 & & \\
\hline & ТРВ & 30 & & & & 0.58 & & 9.5 & & & 101 & & \\
\hline & TPB & 30 & & & & 0.58 & & 9.5 & & & 149 & & \\
\hline & TPB & 30 & & & & 0.68 & & 9.5 & & & 95 & & \\
\hline & TPB & 30 & & & & 0.68 & & 9.5 & & & 111 & & \\
\hline \multirow[t]{12}{*}{ LTH } & TPB & 28 & & & & 0.4 & & 8 & & & 112 & & \\
\hline & ТPB & 28 & & & & 0.4 & & 8 & & & 143 & & \\
\hline & TPB & 28 & & & & 0.4 & & 8 & & & 165 & & \\
\hline & ТPB & 28 & & & & 0.8 & & 8 & & & 122 & & \\
\hline & TPB & 28 & & & & 0.8 & & 8 & & & 113 & & \\
\hline & TPB & 28 & & & & 0.8 & & 8 & & & 123 & & \\
\hline & ТPB & 28 & & & & 0.4 & & 12 & & & 91 & & \\
\hline & TPB & 28 & & & & 0.4 & & 12 & & & 139 & & \\
\hline & TPB & 28 & & & & 0.4 & & 12 & & & 147 & & \\
\hline & ТPB & 28 & & & & 0.8 & & 12 & & & 64 & & \\
\hline & ТPB & 28 & & & & 0.8 & & 12 & & & 74 & & \\
\hline & TPB & 28 & & & & 0.8 & & 12 & & & 74 & & \\
\hline \multirow[t]{5}{*}{ MPA } & ТPB & 28 & & & & 0.54 & & 32 & & & 142 & & \\
\hline & TPB & 28 & & & & 0.54 & & 32 & & & 142 & & \\
\hline & TPB & 28 & & & & 0.54 & & 32 & & & 170 & & \\
\hline & ТPB & 40 & & & & 0.54 & & 32 & & & 137 & & \\
\hline & TPB & 28 & & & & 0.54 & & 2 & & & $\begin{array}{l}53 \\
(\mathrm{col}\end{array}$ & еа ор & page) \\
\hline
\end{tabular}


Table 1 (continued)

\begin{tabular}{|c|c|c|c|c|c|c|c|c|c|c|c|c|c|}
\hline References & $\begin{array}{l}\text { Test } \\
\text { type }\end{array}$ & $\begin{array}{l}\text { Test } \\
\text { age }\end{array}$ & $\begin{array}{l}f_{\mathrm{c}}^{\prime} \\
(\mathrm{MPa})\end{array}$ & $\begin{array}{l}F_{\mathrm{t}}^{\prime} \\
(\mathrm{MPa})\end{array}$ & $\begin{array}{l}E \\
(\mathrm{GPa})\end{array}$ & $w / c$ & $\begin{array}{l}\text { Aggregate } \\
\text { type }\end{array}$ & $\begin{array}{l}d_{\mathrm{a}} \\
(\mathrm{mm})\end{array}$ & $\begin{array}{l}K_{\mathrm{c}} \\
\left(\mathrm{MPa} \mathrm{m}^{1 / 2}\right)\end{array}$ & $\begin{array}{l}\delta_{\mathrm{CTODc}} \\
(\mathrm{mm})\end{array}$ & $\begin{array}{l}G_{\mathrm{F}} \\
(\mathrm{N} / \mathrm{m})\end{array}$ & $\begin{array}{l}G_{\mathrm{f}} \\
(\mathrm{N} / \mathrm{m})\end{array}$ & $\begin{array}{l}c_{\mathrm{f}} \\
(\mathrm{mm})\end{array}$ \\
\hline & ТPB & 28 & & & & 0.54 & & 2 & & & 49 & & \\
\hline & ТPB & 28 & & & & 0.54 & & 2 & & & 44 & & \\
\hline \multirow[t]{3}{*}{ UP } & ТРВ & 28 & & & & 0.58 & & 20 & & & 123 & & \\
\hline & ТPB & 28 & & & & 0.58 & & 20 & & & 132 & & \\
\hline & TPB & 28 & & & & 0.58 & & 20 & & & 140 & & \\
\hline [46] & & & & 2.76 & 22.8 & & & 3.99 & & & & 17.5 & \\
\hline \multirow[t]{5}{*}{ [47] } & TPB & 28 & 31 & 2.7 & 32.3 & 0.54 & RhR & 32 & & & 142 & & \\
\hline & ТPB & 40 & 31 & 2.7 & 32.3 & 0.54 & RhR & 32 & & & 170 & & \\
\hline & ТPB & 28 & 35 & 3 & 25.7 & 0.54 & RhR & 2 & & & 53 & & \\
\hline & ТPB & 28 & 35 & 3 & 25.7 & 0.54 & RhR & 2 & & & 49.3 & & \\
\hline & TPB & 40 & 35 & 3 & 25.7 & 0.54 & RhR & 2 & & & 37.6 & & \\
\hline \multirow[t]{4}{*}{ [48] } & TPB & $28^{(\mathrm{min})}$ & 93 & 3.8 & 32 & 0.4 & $\mathrm{CA}$ & 8 & 1.123 & & 140 & & \\
\hline & TPB & $28^{(\min )}$ & 28 & 2.4 & 31 & 0.8 & $\mathrm{CA}$ & 8 & 0.743 & & 119 & & \\
\hline & TPB & $28^{(\min )}$ & 68 & 3.6 & 39 & 0.4 & NA & 12 & 1.103 & & 126 & & \\
\hline & ТРB & $28^{(\min )}$ & 21 & 2.33 & 26 & 0.8 & NA & 12 & 0.57 & & 71 & & \\
\hline \multirow[t]{8}{*}{ [49] } & ТРВ & $16^{(\mathrm{min})}$ & 21.8 & & & 0.78 & & 12.7 & 0.865 & & & & \\
\hline & TPB & $49^{(\min )}$ & 24.7 & & & 0.78 & & 12.7 & 1.025 & & & & \\
\hline & FPB & $31^{(\min )}$ & 24.4 & & & 0.78 & & 12.7 & 0.777 & & & & \\
\hline & FPB & $59^{(\mathrm{min})}$ & 27.9 & & & 0.78 & & 12.7 & 0.854 & & & & \\
\hline & ТPB & $44^{(\min )}$ & 51.6 & & & 0.5 & & 12.7 & 0.991 & & & & \\
\hline & TPB & $56^{(\mathrm{min})}$ & 52.9 & & & 0.5 & & 12.7 & 1.541 & & & & \\
\hline & FPB & $70^{(\min )}$ & 56 & & & 0.5 & & 12.7 & 0.901 & & & & \\
\hline & FPB & $96^{(\min )}$ & 55 & & & 0.5 & & 12.7 & 1.182 & & & & \\
\hline \multirow[t]{5}{*}[50,51]{} & ТPB & 90 & 25.2 & 2.57 & 33.6 & 0.65 & & 19.1 & 1.09 & 0.016 & & 35.4 & \\
\hline & ТРВ & 90 & 27.2 & 3.14 & 25.4 & 0.65 & & 4.76 & 0.732 & 0.0092 & & 21.1 & \\
\hline & TPB & 90 & 39.4 & 4.29 & 32.5 & 0.45 & & 4.76 & 0.958 & 0.0097 & & 28.3 & \\
\hline & ТPB & & 54.8 & 4.41 & 37.3 & 0.25 & & 4.76 & 1.059 & 0.01 & & 30.1 & \\
\hline & TPB & & & & & 0.45 & & 0 & & & & & \\
\hline [52] & ТPB & & 110 & & 56.6 & 0.22 & & 8 & 2.13 & 0.0338 & & & \\
\hline \multirow[t]{12}{*}{ [53] } & FPB & & & & 27.9 & 0.5 & - & & & & & 14.3 & \\
\hline & TPB & & & & 27.9 & 0.5 & - & & & & & 16.2 & \\
\hline & FPB & & & & 27.9 & 0.5 & - & & & & & 19.9 & \\
\hline & ТPB & & & & 27.9 & 0.5 & - & & & & & 25.8 & \\
\hline & FPB & & & & 37.7 & 0.5 & $\mathrm{CL}$ & 19.1 & & & & 14.5 & \\
\hline & ТРВ & & & & 37.7 & 0.5 & $\mathrm{CL}$ & 19.1 & & & & 17.8 & \\
\hline & FPB & & & & 37.7 & 0.5 & $\mathrm{CL}$ & 19.1 & & & & 25.3 & \\
\hline & TPB & & & & 37.7 & 0.5 & $\mathrm{CL}$ & 19.1 & & & & 30.9 & \\
\hline & FPB & & & 2.07 & 28.9 & 0.6 & QG & 19.1 & & & & 10.7 & \\
\hline & TPB & & & 2.07 & 28.9 & 0.6 & QG & 19.1 & & & & 11.4 & \\
\hline & FPB & & & 2.07 & 28.9 & 0.6 & QG & 19.1 & & & & 16.6 & \\
\hline & ТРВ & & & 2.07 & 28.9 & 0.6 & QG & 19.1 & & & & 18.7 & \\
\hline \multirow[t]{5}{*}[55,56]{} & ТPB & 28 & 26.8 & 2.58 & 24.6 & 0.77 & $\mathrm{CB}$ & 20 & 0.992 & 0.0332 & & & \\
\hline & ТPB & 28 & 39 & 3.11 & 33.8 & 0.64 & $\mathrm{CB}$ & 20 & 1.265 & 0.0263 & & & \\
\hline & TPB & 28 & 49.4 & 3.5 & 34.7 & 0.5 & $\mathrm{CB}$ & 20 & 1.376 & 0.0261 & & & \\
\hline & TPB & 28 & 67.5 & 4.09 & 37.2 & 0.36 & $\mathrm{CB}$ & 20 & 1.502 & 0.0242 & & & \\
\hline & ТPB & 28 & 78.2 & 4.41 & 40.3 & 0.2 & $\mathrm{CB}$ & 20 & 1.881 & 0.0262 & & & \\
\hline \multirow[t]{15}{*}[59,60]{} & TPB & 27 & 29 & 3.1 & 21.7 & 0.6 & GRA & 10 & & & 72.3 & & \\
\hline & ТРВ & 27 & 29 & 3.1 & 21.7 & 0.6 & GRA & 10 & & & 79.7 & & \\
\hline & TPB & 27 & 29 & 3.1 & 21.7 & 0.6 & GRA & 10 & & & 85.6 & & \\
\hline & ТРВ & 28 & 29 & 3.1 & 21.7 & 0.6 & GRA & 10 & & & 70.5 & & \\
\hline & ТРВ & 28 & 29 & 3.1 & 21.7 & 0.6 & GRA & 10 & & & 75.7 & & \\
\hline & ТРB & 28 & 29 & 3.1 & 21.7 & 0.6 & GRA & 10 & & & 72.4 & & \\
\hline & TPB & 29 & 29 & 3.1 & 21.7 & 0.6 & GRA & 10 & & & 83.4 & & \\
\hline & ТРВ & 29 & 29 & 3.1 & 21.7 & 0.6 & GRA & 10 & & & 75.3 & & \\
\hline & ТPB & 29 & 29 & 3.1 & 21.7 & 0.6 & GRA & 10 & & & 68.1 & & \\
\hline & TPB & 32 & 29 & 3.1 & 21.7 & 0.6 & GRA & 10 & & & 68.6 & & \\
\hline & TPB & 32 & 29 & 3.1 & 21.7 & 0.6 & GRA & 10 & & & 84.1 & & \\
\hline & ТРВ & 32 & 29 & 3.1 & 21.7 & 0.6 & GRA & 10 & & & 79.8 & & \\
\hline & ТРВ & 28 & 58.9 & 4.2 & 24.5 & 0.4 & GRA & 10 & & & 80.8 & & \\
\hline & ТРВ & 29 & 58.9 & 4.2 & 24.5 & 0.4 & GRA & 10 & & & 85.3 & & \\
\hline & TPB & 32 & 58.9 & 4.2 & 24.5 & 0.4 & GRA & 10 & & & 69 & & \\
\hline
\end{tabular}


Table 1 (continued)

\begin{tabular}{|c|c|c|c|c|c|c|c|c|c|c|c|c|c|}
\hline References & $\begin{array}{l}\text { Test } \\
\text { type }\end{array}$ & $\begin{array}{l}\text { Test } \\
\text { age }\end{array}$ & $\begin{array}{l}f_{\mathrm{c}}^{\prime} \\
(\mathrm{MPa})\end{array}$ & $\begin{array}{l}F_{\mathrm{t}}^{\prime} \\
(\mathrm{MPa})\end{array}$ & $\begin{array}{l}E \\
(\mathrm{GPa})\end{array}$ & $w / c$ & $\begin{array}{l}\text { Aggregate } \\
\text { type }\end{array}$ & $\begin{array}{l}d_{\mathrm{a}} \\
(\mathrm{mm})\end{array}$ & $\begin{array}{l}K_{\mathrm{c}} \\
\left(\mathrm{MPa} \mathrm{m}{ }^{1 / 2}\right)\end{array}$ & $\begin{array}{l}\delta_{\text {CTODc }} \\
(\mathrm{mm})\end{array}$ & $\begin{array}{l}G_{\mathrm{F}} \\
(\mathrm{N} / \mathrm{m})\end{array}$ & $\begin{array}{l}G_{\mathrm{f}} \\
(\mathrm{N} / \mathrm{m})\end{array}$ & $\begin{array}{l}c_{\mathrm{f}} \\
(\mathrm{mm})\end{array}$ \\
\hline & TPB & 33 & 58.9 & 4.2 & 24.5 & 0.4 & GRA & 10 & & & 74.2 & & \\
\hline & ТPB & 28 & 58.9 & 4.2 & 24.5 & 0.4 & GRA & 10 & & & 58.9 & & \\
\hline & TPB & 29 & 58.9 & 4.2 & 24.5 & 0.4 & GRA & 10 & & & 76.9 & & \\
\hline & ТРB & 32 & 58.9 & 4.2 & 24.5 & 0.4 & GRA & 10 & & & 60.8 & & \\
\hline & ТРB & 33 & 58.9 & 4.2 & 24.5 & 0.4 & GRA & 10 & & & 62.7 & & \\
\hline & ТPB & 28 & 58.9 & 4.2 & 24.5 & 0.4 & GRA & 10 & & & 44.9 & & \\
\hline & TPB & 29 & 58.9 & 4.2 & 24.5 & 0.4 & GRA & 10 & & & 43.8 & & \\
\hline & ТPB & 32 & 58.9 & 4.2 & 24.5 & 0.4 & GRA & 10 & & & 62.5 & & \\
\hline & TPB & 33 & 58.9 & 4.2 & 24.5 & 0.4 & GRA & 10 & & & 43.6 & & \\
\hline & ТPB & 28 & 33.1 & 3.5 & 19.7 & 0.55 & GRA & 10 & & & 76.6 & & \\
\hline & TPB & 29 & 33.1 & 3.5 & 19.7 & 0.55 & GRA & 10 & & & 81.9 & & \\
\hline & TPB & 30 & 33.1 & 3.5 & 19.7 & 0.55 & GRA & 10 & & & 71.6 & & \\
\hline & ТPB & 32 & 33.1 & 3.5 & 19.7 & 0.55 & GRA & 10 & & & 59.2 & & \\
\hline & TPB & 28 & 33.1 & 3.5 & 19.7 & 0.55 & GRA & 10 & & & 84.7 & & \\
\hline & TPB & 29 & 33.1 & 3.5 & 19.7 & 0.55 & GRA & 10 & & & 89.5 & & \\
\hline & TPB & 30 & 33.1 & 3.5 & 19.7 & 0.55 & GRA & 10 & & & 90.7 & & \\
\hline & ТРB & 32 & 33.1 & 3.5 & 19.7 & 0.55 & GRA & 10 & & & 92.2 & & \\
\hline \multirow[t]{3}{*}{ [61] } & ТPB & 38 & 48.5 & & & 0.38 & & 13 & 0.42 & & 80.6 & & \\
\hline & ТPB & 38 & 48.5 & & & 0.38 & & 13 & 0.41 & & 82.6 & & \\
\hline & ТРВ & 38 & 48.5 & & & 0.38 & & 13 & 0.61 & & 115 & & \\
\hline [62] & FPB & 68 & & 7.32 & 43.2 & 0.36 & PG & 9.53 & 0.875 & & & & \\
\hline \multirow[t]{2}{*}{ [63] } & TPB & 21 & 46.6 & & & 0.48 & OS & & 0.469 & & & & \\
\hline & ТPB & 34 & 56.1 & & & 0.45 & GRA & 9.5 & 0.757 & & & & \\
\hline \multirow[t]{9}{*}{ [64] } & TPB & & & & & 0.4 & & & & & & & \\
\hline & ТPB & 3 & & & & 0.5 & & & 0.135 & & & & \\
\hline & ТPB & 7 & & & & 0.5 & & & 0.151 & & & & \\
\hline & ТРB & & & & & 0.7 & & & & & & & \\
\hline & ТPB & & & & & 0.4 & GLA & 12.7 & & & & & \\
\hline & ТPB & 7 & & & & 0.5 & GLA & 12.7 & 0.226 & & & & \\
\hline & TPB & 14 & & & & 0.5 & GLA & 12.7 & 0.241 & & & & \\
\hline & TPB & 28 & & & & 0.5 & GLA & 12.7 & 0.256 & & & & \\
\hline & ТPB & & & & & 0.6 & GLA & 12.7 & & & & & \\
\hline \multirow[t]{29}{*}{ [65] } & TPB & & 44.3 & & 26.3 & 0.5 & RRG & 2 & & & 58.4 & 38.1 & \\
\hline & TPB & & 42.1 & & 29.5 & 0.5 & RRG & 5 & & & 63.3 & 33.3 & \\
\hline & ТРB & & 39.9 & & 31.3 & 0.5 & RRG & 10 & & & 63.2 & 28.4 & \\
\hline & ТPB & & 39.9 & & 31.3 & 0.5 & RRG & 10 & & & 72.3 & 33.1 & \\
\hline & TPB & & 39.9 & & 31.3 & 0.5 & RRG & 10 & & & 77 & 33.5 & \\
\hline & TPB & & 39.9 & & 31.3 & 0.5 & RRG & 10 & & & 95.5 & 35.8 & \\
\hline & TPB & & 44.3 & & 26.3 & 0.5 & RRG & 2 & & & 55.2 & 36.4 & \\
\hline & ТPB & & 42.1 & & 29.5 & 0.5 & RRG & 5 & & & 54.7 & 34.8 & \\
\hline & ТРB & & 39.9 & & 31.3 & 0.5 & RRG & 10 & & & 64.6 & 34.3 & \\
\hline & TPB & & 39.9 & & 31.3 & 0.5 & RRG & 14 & & & 58.6 & 32.8 & \\
\hline & ТPB & & 39.9 & & 31.3 & 0.5 & RRG & 14 & & & 64.4 & 32.4 & \\
\hline & ТPB & & 39.9 & & 31.3 & 0.5 & RRG & 14 & & & 80 & 34.5 & \\
\hline & TPB & & 39.9 & & 31.3 & 0.5 & RRG & 14 & & & 97.2 & 36.9 & \\
\hline & TPB & & 44.3 & & 26.3 & 0.5 & RRG & 2 & & & 61.3 & 38.7 & \\
\hline & TPB & & 42.1 & & 29.5 & 0.5 & RRG & 5 & & & 61.4 & 35.4 & \\
\hline & $\mathrm{TPB}$ & & 39.9 & & 31.3 & 0.5 & RRG & 10 & & & 65.8 & 32.8 & \\
\hline & TPB & & 39.9 & & 31.3 & 0.5 & RRG & 14 & & & 73.7 & 35.7 & \\
\hline & ТPB & & 37.6 & & 33 & 0.5 & RRG & 20 & & & 64.4 & 26.9 & \\
\hline & TPB & & 37.6 & & 33 & 0.5 & RRG & 20 & & & 83.5 & 28.8 & \\
\hline & TPB & & 37.6 & & 33 & 0.5 & RRG & 20 & & & 93.9 & 30.5 & \\
\hline & TPB & & 37.6 & & 33 & 0.5 & RRG & 20 & & & 106 & 32.7 & \\
\hline & ТPB & & 38.5 & & 34.4 & 0.5 & RRG & 20 & & & 78 & 29.9 & \\
\hline & ТPB & & 34.2 & & 32.6 & 0.55 & RRG & 20 & & & 69.9 & 28.8 & \\
\hline & ТPB & & 28 & & 28.5 & 0.6 & RRG & 20 & & & 56.7 & 27.6 & \\
\hline & ТРB & & 23.8 & & 24 & 0.65 & RRG & 20 & & & 47.2 & 23.4 & \\
\hline & ТPB & & 41.3 & & 33.2 & 0.5 & CRG & 20 & & & 101 & 43 & \\
\hline & TPB & & 35.8 & & 28.2 & 0.55 & $\mathrm{CRG}$ & 20 & & & 88.3 & 41 & \\
\hline & ТPB & & 30.2 & & 23.6 & 0.6 & $\mathrm{CRG}$ & 20 & & & 75.8 & 39 & \\
\hline & ТPB & & 24.9 & & 21 & 0.65 & $\mathrm{CRG}$ & 20 & & & $\begin{array}{c}59.2 \\
\text { (cont }\end{array}$ & $\begin{array}{c}28.3 \\
\text { ed on }\end{array}$ & \\
\hline
\end{tabular}


Table 1 (continued)

\begin{tabular}{|c|c|c|c|c|c|c|c|c|c|c|c|c|c|}
\hline References & $\begin{array}{l}\text { Test } \\
\text { type }\end{array}$ & $\begin{array}{l}\text { Test } \\
\text { age }\end{array}$ & $\begin{array}{l}f_{\mathrm{c}}^{\prime} \\
(\mathrm{MPa})\end{array}$ & $\begin{array}{l}F_{\mathrm{t}}^{\prime} \\
(\mathrm{MPa})\end{array}$ & $\begin{array}{l}E \\
(\mathrm{GPa})\end{array}$ & $w / c$ & $\begin{array}{l}\text { Aggregate } \\
\text { type }\end{array}$ & $\begin{array}{l}d_{\mathrm{a}} \\
(\mathrm{mm})\end{array}$ & $\begin{array}{l}K_{\mathrm{c}} \\
\left(\mathrm{MPa} \mathrm{m}^{1 / 2}\right)\end{array}$ & $\begin{array}{l}\delta_{\mathrm{CTODc}} \\
(\mathrm{mm})\end{array}$ & $\begin{array}{l}G_{\mathrm{F}} \\
(\mathrm{N} / \mathrm{m})\end{array}$ & $\begin{array}{l}G_{\mathrm{f}} \\
(\mathrm{N} / \mathrm{m})\end{array}$ & $\begin{array}{l}c_{\mathrm{f}} \\
(\mathrm{mm})\end{array}$ \\
\hline & ТPB & & 38.5 & & 34.4 & 0.5 & RRG & 20 & & & 69.5 & 28 & \\
\hline & ТРВ & & 38.5 & & 34.4 & 0.5 & RRG & 20 & & & 77.1 & 35.1 & \\
\hline & ТРB & & 38.5 & & 34.4 & 0.5 & RRG & 20 & & & 84.6 & 34 & \\
\hline & ТРВ & & 38.5 & & 34.4 & 0.5 & RRG & 20 & & & 78.6 & 35.5 & \\
\hline & ТРВ & & 38.5 & & 34.4 & 0.5 & RRG & 20 & & & 96.2 & 39.2 & \\
\hline & ТРВ & & 38.5 & & 34.4 & 0.5 & RRG & 20 & & & 103 & 40.4 & \\
\hline & ТРВ & & 38.5 & & 34.4 & 0.5 & RRG & 20 & & & 111 & 41 & \\
\hline \multirow[t]{29}{*}[68]{} & plates & 28 & & 4.11 & & 0.6 & $\mathrm{CL}$ & 19.1 & 0.749 & & & & \\
\hline & plates & 28 & & 4.11 & & 0.6 & $\mathrm{CL}$ & 19.1 & 0.63 & & & & \\
\hline & plates & 28 & & 4.11 & & 0.6 & $\mathrm{CL}$ & 19.1 & 0.573 & & & & \\
\hline & plates & 33 & & 4.43 & & 0.6 & CL & 19.1 & 0.937 & & & & \\
\hline & plates & 33 & & 4.43 & & 0.6 & $\mathrm{CL}$ & 19.1 & 0.857 & & & & \\
\hline & plates & 33 & & 4.43 & & 0.6 & $\mathrm{CL}$ & 19.1 & 0.698 & & & & \\
\hline & plates & 33 & & 4.43 & & 0.6 & $\mathrm{CL}$ & 19.1 & 0.649 & & & & \\
\hline & plates & 33 & & 4.43 & & 0.6 & $\mathrm{CL}$ & 19.1 & 0.643 & & & & \\
\hline & plates & 40 & & 4.12 & & 0.6 & $\mathrm{CL}$ & 19.1 & 1.423 & & & & \\
\hline & plates & 40 & & 4.12 & & 0.6 & $\mathrm{CL}$ & 19.1 & 1.19 & & & & \\
\hline & plates & 40 & & 4.12 & & 0.6 & $\mathrm{CL}$ & 19.1 & 1.019 & & & & \\
\hline & plates & 40 & & 4.12 & & 0.6 & $\mathrm{CL}$ & 19.1 & 0.853 & & & & \\
\hline & plates & 40 & & 4.12 & & 0.6 & $\mathrm{CL}$ & 19.1 & 0.818 & & & & \\
\hline & plates & 40 & & 4.12 & & 0.6 & $\mathrm{CL}$ & 19.1 & 0.686 & & & & \\
\hline & plates & 40 & & 4.12 & & 0.6 & $\mathrm{CL}$ & 19.1 & 0.687 & & & & \\
\hline & plates & 40 & & 4.12 & & 0.6 & $\mathrm{CL}$ & 19.1 & 0.569 & & & & \\
\hline & plates & 48 & & & & 0.6 & $\mathrm{CL}$ & 19.1 & & & & & \\
\hline & plates & 3 & & 3.17 & & 0.6 & $\mathrm{CL}$ & 9.53 & 0.461 & & & & \\
\hline & plates & 3 & & 3.17 & & 0.6 & $\mathrm{CL}$ & 9.53 & 0.497 & & & & \\
\hline & plates & 3 & & 3.17 & & 0.6 & $\mathrm{CL}$ & 9.53 & 0.508 & & & & \\
\hline & plates & 3 & & 3.17 & & 0.6 & $\mathrm{CL}$ & 9.53 & 0.542 & & & & \\
\hline & plates & 5 & 51 & 2.9 & & 0.6 & $\mathrm{Q}$ & 9.53 & 0.418 & & & & \\
\hline & plates & 5 & 51 & 2.9 & & 0.6 & Q & 9.53 & 0.459 & & & & \\
\hline & plates & 5 & 51 & 2.9 & & 0.6 & Q & 9.53 & 0.494 & & & & \\
\hline & plates & 5 & 51 & 2.9 & & 0.6 & Q & 9.53 & 0.508 & & & & \\
\hline & plates & 4 & 46.3 & 3.81 & & 0.6 & $\mathrm{CL}$ & 19.1 & 0.505 & & & & \\
\hline & plates & 4 & 46.3 & 3.81 & & 0.6 & $\mathrm{CL}$ & 19.1 & 0.538 & & & & \\
\hline & plates & 4 & 46.3 & 3.81 & & 0.6 & $\mathrm{CL}$ & 19.1 & 0.582 & & & & \\
\hline & plates & 4 & 46.3 & 3.81 & & 0.6 & $\mathrm{CL}$ & 19.1 & 0.559 & & & & \\
\hline \multirow[t]{4}{*}{ [69] } & $\mathrm{NC}$ & 35 & 37.9 & & 30.8 & 0.5 & RGRA & 9.5 & 1.237 & & & & \\
\hline & TPB & 35 & 37.9 & & 30.8 & 0.5 & RGRA & 9.5 & 0.624 & & & & \\
\hline & $\mathrm{NC}$ & 35 & 39.2 & & 31.8 & 0.5 & RGRA & 9.5 & 0.561 & & & & \\
\hline & ТРВ & 35 & 39.2 & & 31.8 & 0.5 & RGRA & 9.5 & 0.665 & & & & \\
\hline \multirow[t]{20}{*}{ [72] } & ТРB & 7 & & & & 0.6 & CQ & 8 & & & 94.1 & & \\
\hline & ТРВ & 7 & & & & 0.6 & CQ & 8 & & & 110 & & \\
\hline & ТРВ & 28 & & & 30 & 0.6 & $\mathrm{CQ}$ & 8 & & & 101 & & \\
\hline & ТPB & 28 & & & 30 & 0.6 & CQ & 8 & & & 125 & & \\
\hline & DTT & 7 & & & & 0.6 & $\mathrm{CQ}$ & 8 & & & 87.5 & & \\
\hline & DTT & 7 & & & & 0.6 & CQ & 8 & & & 96.2 & & \\
\hline & DTT & 28 & & & 30 & 0.6 & CQ & 8 & & & 100 & & \\
\hline & DTT & 28 & & & 30 & 0.6 & CQ & 8 & & & 106 & & \\
\hline & ТPB & 28 & 53.6 & 3.8 & 41.9 & 0.5 & $\mathrm{CQ}$ & 12 & & & 104 & & \\
\hline & ТРВ & 28 & 43.9 & 3.45 & 41.3 & 0.5 & GRA & 12 & & & 104 & & \\
\hline & TPB & 28 & 59.8 & 4.55 & 30 & 0.5 & CL & 12 & & & 60 & & \\
\hline & ТРB & 28 & 19.8 & 2.2 & 18.1 & 0.5 & $\mathrm{EC}$ & 12 & & & 38.8 & & \\
\hline & ТРВ & 28 & 85.9 & 4.5 & 48.1 & 0.3 & CQ & 12 & & & 115 & & \\
\hline & TPB & 28 & 74 & 4.3 & 44.4 & 0.4 & CQ & 12 & & & 119 & & \\
\hline & TPB & 28 & 29.8 & 2.45 & 36.3 & 0.7 & CQ & 12 & & & 81.3 & & \\
\hline & ТРВ & 28 & 55.9 & 3.8 & 43.8 & 0.5 & CQ & 12 & & & 123 & & \\
\hline & ТРВ & 28 & 54.4 & 3.8 & 41.3 & 0.5 & CQ & 12 & & & 105 & & \\
\hline & ТРВ & 28 & 52.7 & 4 & 43.1 & 0.5 & $\mathrm{CQ}$ & 8 & & & 101 & & \\
\hline & ТРВ & 28 & 55.3 & 3.4 & 41.9 & 0.5 & $\mathrm{CQ}$ & 16 & & & 111 & & \\
\hline & TPB & 2 & 26.1 & 1.85 & 31.3 & 0.5 & CQ & 12 & & & 82.5 & & \\
\hline
\end{tabular}


Table 1 (continued)

\begin{tabular}{|c|c|c|c|c|c|c|c|c|c|c|c|c|c|}
\hline References & $\begin{array}{l}\text { Test } \\
\text { type }\end{array}$ & $\begin{array}{l}\text { Test } \\
\text { age }\end{array}$ & $\begin{array}{l}f_{\mathrm{c}}^{\prime} \\
(\mathrm{MPa})\end{array}$ & $\begin{array}{l}F_{\mathrm{t}}^{\prime} \\
(\mathrm{MPa})\end{array}$ & $\begin{array}{l}E \\
(\mathrm{GPa})\end{array}$ & $w / c$ & $\begin{array}{l}\text { Aggregate } \\
\text { type }\end{array}$ & $\begin{array}{l}d_{\mathrm{a}} \\
(\mathrm{mm})\end{array}$ & $\begin{array}{l}K_{\mathrm{c}} \\
\left(\mathrm{MPa} \mathrm{m}{ }^{1 / 2}\right)\end{array}$ & $\begin{array}{l}\delta_{\text {CTODc }} \\
(\mathrm{mm})\end{array}$ & $\begin{array}{l}G_{\mathrm{F}} \\
(\mathrm{N} / \mathrm{m})\end{array}$ & $\begin{array}{l}G_{\mathrm{f}} \\
(\mathrm{N} / \mathrm{m})\end{array}$ & $\begin{array}{l}c_{\mathrm{f}} \\
(\mathrm{mm})\end{array}$ \\
\hline & TPB & 7 & 42.4 & 3 & 38.8 & 0.5 & $\mathrm{CQ}$ & 12 & & & 96.3 & & \\
\hline & TPB & 91 & 63 & 4.25 & 44.4 & 0.5 & $\mathrm{CQ}$ & 12 & & & 114 & & \\
\hline \multirow[t]{5}{*}{ [76] } & TPB & & 55.8 & & 36.8 & 0.5 & & 19 & 1.165 & 0.0217 & & & \\
\hline & TPB & & 53.1 & & 38.4 & 0.5 & & 19 & 1.054 & 0.0153 & & & \\
\hline & ТPB & & 54.4 & & 39.3 & 0.5 & & 19 & 1.314 & 0.0249 & & & \\
\hline & TPB & & 53.1 & & 38.4 & 0.5 & & 19 & 1.176 & 0.0316 & & & \\
\hline & TPB & & 54.4 & & 39.3 & 0.5 & & 19 & 1.206 & 0.0312 & & & \\
\hline \multirow[t]{11}{*}{ [80] } & CyWS & 45 & 51 & 3.7 & 36.6 & 0.47 & $\mathrm{SCG}$ & 20 & & & 68.7 & & \\
\hline & CyWS & 150 & 55 & 4.5 & 36 & 0.48 & SCG & 12.5 & & & 68 & & \\
\hline & CyWS & 31 & 60 & 4.7 & 34.2 & 0.53 & SCG & 6.3 & & & 59.8 & & \\
\hline & CyWS & 48 & 44 & 3.8 & 32.5 & 0.53 & SCG & 6.3 & & & 48.8 & & \\
\hline & CuWs & 45 & 51 & 3.7 & 36.6 & 0.47 & $\mathrm{SCG}$ & 20 & & & 87.5 & & \\
\hline & CuWS & 150 & 55 & 4.5 & 36 & 0.48 & SCG & 12.5 & & & 75.9 & & \\
\hline & CuWS & 31 & 60 & 4.7 & 34.2 & 0.53 & SCG & 6.3 & & & 72.7 & & \\
\hline & CuWS & 48 & 44 & 3.8 & 32.5 & 0.53 & $\mathrm{SCG}$ & 6.3 & & & 54.9 & & \\
\hline & TDCB & 45 & 51 & 3.7 & 36.6 & 0.47 & $\mathrm{SCG}$ & 20 & & & 150 & & \\
\hline & TDCB & 150 & 55 & 4.5 & 36 & 0.48 & $\mathrm{SCG}$ & 12.5 & & & 141 & & \\
\hline & TDCB & 48 & 44 & 3.8 & 32.5 & 0.53 & SCG & 6.3 & & & 136 & & \\
\hline \multirow[t]{3}{*}{ [81] } & TPB & & & & & 0.5 & GF & 9.5 & & & 27.5 & & \\
\hline & TPB & & & & & 0.5 & GF & 9.5 & & & 39.1 & & \\
\hline & TPB & & & & & 0.5 & GF & 9.5 & & & 53.9 & & \\
\hline \multirow[t]{10}{*}{ [82] } & TPB & 1 & 34.5 & & 25.2 & 0.4 & PG & 9 & 0.72 & 0.0076 & & 20.6 & 6.94 \\
\hline & ТPB & 3 & 39.3 & & 25.1 & 0.4 & PG & 9 & 0.826 & 0.0132 & & 27.2 & 15.8 \\
\hline & TPB & 7 & 37.2 & & 34 & 0.4 & PG & 9 & 1.021 & 0.0136 & & 30.7 & 20.1 \\
\hline & TPB & 14 & 51.8 & & 39.3 & 0.4 & PG & 9 & 1.208 & 0.0122 & & 37.1 & 15.5 \\
\hline & TPB & 28 & 55.3 & & 37.4 & 0.4 & PG & 9 & 1.184 & 0.0143 & & 37.5 & 20.1 \\
\hline & ТPB & 1 & 45 & & 26.1 & 0.29 & PG & 9 & 0.978 & 0.0091 & & 36.7 & 5.77 \\
\hline & TPB & 3 & 57.3 & & 36.6 & 0.29 & PG & 9 & 1.168 & 0.0107 & & 37.3 & 11 \\
\hline & TPB & 7 & 58.7 & & 37.3 & 0.29 & PG & 9 & 1.175 & 0.0123 & & 37 & 15 \\
\hline & ТPB & 14 & 66.3 & & 36.8 & 0.29 & PG & 9 & 1.346 & 0.0094 & & 49.3 & 6.47 \\
\hline & ТPB & 28 & 87.2 & & 35.7 & 0.29 & PG & 9 & 1.491 & 0.0116 & & 62.3 & 7.56 \\
\hline [83] & $\mathrm{DCB}$ & 28 & 41.3 & 2.5 & 41 & 0.48 & GRA & 12 & 1.6 & & & & \\
\hline \multirow[t]{3}{*}[84,85]{} & TPB & & 73.3 & & 40.5 & 0.33 & BA & 4.76 & 0.868 & & & 18.6 & \\
\hline & ТPB & & 72 & & 40.1 & 0.33 & GREY & 4.76 & 0.878 & & & 19.2 & \\
\hline & TPB & & 71.1 & & 39.9 & 0.53 & & 2.36 & 0.698 & & & 12.2 & \\
\hline \multirow[t]{7}{*}{ [86] } & TPB & 28 & 33.6 & & 27.4 & 0.52 & $\mathrm{CL}$ & 9.5 & 0.933 & & & 31.8 & 16.4 \\
\hline & $\mathrm{EC}$ & 28 & 33.6 & & 27.4 & 0.52 & $\mathrm{CL}$ & 9.5 & 1.18 & & & 50.1 & 21 \\
\hline & ST & 28 & 31.4 & & 26.5 & 0.52 & $\mathrm{CL}$ & 12.7 & 0.841 & & & 26.7 & 12.5 \\
\hline & $\mathrm{EC}$ & 28 & 31.4 & & 26.5 & 0.52 & $\mathrm{CL}$ & 12.7 & 0.908 & & & 31.1 & 15.9 \\
\hline & OSB & 28 & 31.4 & & 26.5 & 0.52 & CL & 12.7 & 0.956 & & & 34.5 & 5.6 \\
\hline & TPB & 28 & 34.5 & & 27.8 & 0.52 & CL & 12.7 & 1.27 & & & 58 & 22.3 \\
\hline & $\mathrm{EC}$ & 28 & & & & 0.5 & CL & 16 & 0.852 & & & 28.1 & 14.6 \\
\hline \multirow[t]{3}{*}{ [87] } & TPB & & 34.5 & & 27.8 & 0.5 & & 3 & 0.84 & 0.0088 & & 25.4 & \\
\hline & TPB & & 34.5 & & 27.8 & 0.5 & & 3 & 0.882 & 0.008 & & 28 & \\
\hline & ТPB & & 34.5 & & 27.8 & 0.5 & & 3 & 0.865 & 0.0047 & & 26.9 & \\
\hline \multirow[t]{9}{*}{ [88] } & ТPB & $34-42$ & 48.2 & 4.46 & 39.7 & 0.56 & $\mathrm{CL}$ & 10 & & & 67.7 & & \\
\hline & TPB & $35-43$ & 82.7 & 6.25 & 47.2 & 0.45 & CL & 10 & & & 57.6 & & \\
\hline & $\mathrm{TPB}$ & $38-44$ & 117 & 7.69 & 47.8 & 0.24 & $\mathrm{CL}$ & 10 & & & 53.8 & & \\
\hline & $\mathrm{CCS}$ & $34-42$ & 48.2 & 4.46 & 39.7 & 0.56 & $\mathrm{CL}$ & 10 & & & 58.1 & & \\
\hline & $\mathrm{CCS}$ & $35-43$ & 82.7 & 6.25 & 47.2 & 0.45 & $\mathrm{CL}$ & 10 & & & 46.6 & & \\
\hline & $\mathrm{CCS}$ & $38-44$ & 117 & 7.69 & 47.8 & 0.24 & CL & 10 & & & 48 & & \\
\hline & CTS & 34_42 & 48.2 & 4.46 & 39.7 & 0.56 & $\mathrm{CL}$ & 10 & & & 60.8 & & \\
\hline & CTS & 35_43 & 82.7 & 6.25 & 47.2 & 0.45 & $\mathrm{CL}$ & 10 & & & 68.9 & & \\
\hline & CTS & 38_44 & 117 & 7.69 & 47.8 & 0.24 & CL & -10 & & & 53.7 & & \\
\hline \multirow[t]{6}{*}{ [89] } & TPB & & 23.1 & 5.42 & & & $\mathrm{CS}$ & 12.5 & 0.836 & & & & \\
\hline & TPB & & 35.4 & 5.57 & & & $\mathrm{CS}$ & 12.5 & 0.951 & & & & \\
\hline & TPB & & 14.3 & 3.91 & & & $\mathrm{CS}$ & 12.5 & 0.591 & & & & \\
\hline & TPB & & 15.7 & 3.9 & & & $\mathrm{CS}$ & 12.5 & 0.535 & & & & \\
\hline & TPB & & 46.8 & 7.1 & & & $\mathrm{CS}$ & 12.5 & 1.072 & & & & \\
\hline & ТPB & & 32.8 & 6.15 & & & $\mathrm{CS}$ & 12.5 & 0.936 & & & & \\
\hline [90] & & & 67.1 & 5.1 & 20.7 & 0.3 & & 6.35 & & & & 149 & \\
\hline
\end{tabular}


Table 1 (continued)

\begin{tabular}{|c|c|c|c|c|c|c|c|c|c|c|c|c|c|}
\hline References & $\begin{array}{l}\text { Test } \\
\text { type }\end{array}$ & $\begin{array}{l}\text { Test } \\
\text { age }\end{array}$ & $\begin{array}{l}f_{\mathrm{c}}^{\prime} \\
(\mathrm{MPa})\end{array}$ & $\begin{array}{l}F_{\mathrm{t}}^{\prime} \\
(\mathrm{MPa})\end{array}$ & $\begin{array}{l}E \\
(\mathrm{GPa})\end{array}$ & $w / c$ & $\begin{array}{l}\text { Aggregate } \\
\text { type }\end{array}$ & $\begin{array}{l}d_{\mathrm{a}} \\
(\mathrm{mm})\end{array}$ & $\begin{array}{l}K_{\mathrm{c}} \\
\left(\mathrm{MPa} \mathrm{m}{ }^{1 / 2}\right)\end{array}$ & $\begin{array}{l}\delta_{\text {CTODc }} \\
(\mathrm{mm})\end{array}$ & $\begin{array}{l}G_{\mathrm{F}} \\
(\mathrm{N} / \mathrm{m})\end{array}$ & $\begin{array}{l}G_{\mathrm{f}} \\
(\mathrm{N} / \mathrm{m})\end{array}$ & $\begin{array}{l}c_{\mathrm{f}} \\
(\mathrm{mm})\end{array}$ \\
\hline \multirow[t]{3}{*}{ [91] } & DTB & & & & & 0.5 & & & & & & 161 & \\
\hline & DTB & & & & & 0.5 & & & & & & 117 & \\
\hline & DTB & & & & & 0.5 & & & & & & 97.7 & \\
\hline \multirow[t]{7}{*}{ [92] } & TPB & 2 & & 3.4 & 23 & 0.5 & RRG & 12.7 & & & 80.6 & & \\
\hline & $\mathrm{TPB}$ & 5 & & 3.25 & 22 & 0.5 & RRG & 12.7 & & & 101 & & \\
\hline & TPB & 7 & & 3.7 & 27 & 0.5 & RRG & 12.7 & & & 89.8 & & \\
\hline & TPB & 10 & & 4 & 30 & 0.5 & RRG & 12.7 & & & 107 & & \\
\hline & TPB & 14 & & 3.4 & 28.5 & 0.5 & RRG & 12.7 & & & 111 & & \\
\hline & TPB & 21 & & 4 & 29.5 & 0.5 & RRG & 12.7 & & & 96.4 & & \\
\hline & TPB & 28 & & 4.5 & 27 & 0.5 & RRG & 12.7 & & & 113 & & \\
\hline \multirow[t]{51}{*}{ [93] } & TPB & 1.22 & 7.77 & & & 0.5 & $\mathrm{AG}$ & 9.5 & & & 36.8 & & \\
\hline & ТРB & 2.04 & 20.7 & & & 0.5 & $\mathrm{AG}$ & 9.5 & & & 61.3 & & \\
\hline & TPB & 4.03 & 31.9 & & & 0.5 & $\mathrm{AG}$ & 9.5 & & & 85.8 & & \\
\hline & TPB & 7.25 & 36.6 & & & 0.5 & $\mathrm{AG}$ & 9.5 & & & 89.4 & & \\
\hline & TPB & 22 & 42 & & & 0.5 & $\mathrm{AG}$ & 9.5 & & & 98.1 & & \\
\hline & TPB & 36 & 44.6 & & & 0.5 & $\mathrm{AG}$ & 9.5 & & & 103 & & \\
\hline & TPB & 1 & 3.01 & & & 0.5 & $\mathrm{AG}$ & 9.5 & & & 29.8 & & \\
\hline & TPB & 2 & 20.7 & & & 0.5 & $\mathrm{AG}$ & 9.5 & & & 61.3 & & \\
\hline & TPB & 4.1 & 31.9 & & & 0.5 & $\mathrm{AG}$ & 9.5 & & & 84.1 & & \\
\hline & ТРB & 10 & 40.1 & & & 0.5 & $\mathrm{AG}$ & 9.5 & & & 92.9 & & \\
\hline & ТРB & 22 & 42 & & & 0.5 & $\mathrm{AG}$ & 9.5 & & & 92.9 & & \\
\hline & TPB & 38 & 44.6 & & & 0.5 & $\mathrm{AG}$ & 9.5 & & & 98.1 & & \\
\hline & ТPB & 1.1 & 3.01 & & & 0.5 & $\mathrm{AG}$ & 9.5 & & & 35 & & \\
\hline & TPB & 2.1 & 20.7 & & & 0.5 & $\mathrm{AG}$ & 9.5 & & & 57.8 & & \\
\hline & ТРB & 4 & 31.9 & & & 0.5 & $\mathrm{AG}$ & 9.5 & & & 82.3 & & \\
\hline & ТPB & 9 & 39.3 & & & 0.5 & $\mathrm{AG}$ & 9.5 & & & 89.4 & & \\
\hline & TPB & 18 & 42 & & & 0.5 & $\mathrm{AG}$ & 9.5 & & & 94.6 & & \\
\hline & TPB & 36 & 44.6 & & & 0.5 & $\mathrm{AG}$ & 9.5 & & & 99.9 & & \\
\hline & TPB & 0.5 & 4.98 & & & 0.5 & $\mathrm{AG}$ & 9.5 & & & 35 & & \\
\hline & TPB & 1.3 & 18.8 & & & 0.5 & $\mathrm{AG}$ & 9.5 & & & 64.8 & & \\
\hline & TPB & 3.06 & 25.9 & & & 0.5 & $\mathrm{AG}$ & 9.5 & & & 87.6 & & \\
\hline & ТРB & 7.16 & 36.3 & & & 0.5 & $\mathrm{AG}$ & 9.5 & & & 92.9 & & \\
\hline & TPB & 14 & 38.3 & & & 0.5 & $\mathrm{AG}$ & 9.5 & & & 98.1 & & \\
\hline & TPB & 28 & 41.8 & & & 0.5 & $\mathrm{AG}$ & 9.5 & & & 102 & & \\
\hline & ТPB & 0.56 & 4.98 & & & 0.5 & $\mathrm{AG}$ & 9.5 & & & 38.5 & & \\
\hline & ТPB & 1.21 & 18.8 & & & 0.5 & $\mathrm{AG}$ & 9.5 & & & 59.6 & & \\
\hline & TPB & 2.95 & 25.9 & & & 0.5 & $\mathrm{AG}$ & 9.5 & & & 84.1 & & \\
\hline & TPB & 7.16 & 36.3 & & & 0.5 & $\mathrm{AG}$ & 9.5 & & & 91.1 & & \\
\hline & ТPB & 14 & 38.3 & & & 0.5 & $\mathrm{AG}$ & 9.5 & & & 94.6 & & \\
\hline & ТРB & 28 & 41.8 & & & 0.5 & $\mathrm{AG}$ & 9.5 & & & 92.9 & & \\
\hline & TPB & 0.65 & 4.98 & & & 0.5 & $\mathrm{AG}$ & 9.5 & & & 38.5 & & \\
\hline & TPB & 1 & 18.8 & & & 0.5 & $\mathrm{AG}$ & 9.5 & & & 66.6 & & \\
\hline & TPB & 3 & 25.9 & & & 0.5 & $\mathrm{AG}$ & 9.5 & & & 78.8 & & \\
\hline & TPB & 7 & 36.3 & & & 0.5 & $\mathrm{AG}$ & 9.5 & & & 89.4 & & \\
\hline & TPB & 14 & 38.3 & & & 0.5 & $\mathrm{AG}$ & 9.5 & & & 94.6 & & \\
\hline & TPB & 28 & 41.8 & & & 0.5 & $\mathrm{AG}$ & 9.5 & & & 99.9 & & \\
\hline & ТРB & 0.35 & 12 & & & 0.5 & $\mathrm{AG}$ & 9.5 & & & 38.5 & & \\
\hline & TPB & 0.56 & 16.6 & & & 0.5 & $\mathrm{AG}$ & 9.5 & & & 66.6 & & \\
\hline & TPB & 1.07 & 25.6 & & & 0.5 & $\mathrm{AG}$ & 9.5 & & & 80.6 & & \\
\hline & ТPB & 4.03 & 30.9 & & & 0.5 & $\mathrm{AG}$ & 9.5 & & & 92.9 & & \\
\hline & ТPB & 9.5 & 35.1 & & & 0.5 & $\mathrm{AG}$ & 9.5 & & & 98.1 & & \\
\hline & TPB & 20 & 37.5 & & & 0.5 & $\mathrm{AG}$ & 9.5 & & & 99.9 & & \\
\hline & TPB & 0.25 & 12 & & & 0.5 & $\mathrm{AG}$ & 9.5 & & & 31.5 & & \\
\hline & ТРB & 1.55 & 25.6 & & & 0.5 & $\mathrm{AG}$ & 9.5 & & & 87.6 & & \\
\hline & TPB & 4.26 & 30.9 & & & 0.5 & $\mathrm{AG}$ & 9.5 & & & 89.4 & & \\
\hline & TPB & 9.05 & 35.1 & & & 0.5 & $\mathrm{AG}$ & 9.5 & & & 94.6 & & \\
\hline & ТPB & 20.2 & 37.5 & & & 0.5 & $\mathrm{AG}$ & 9.5 & & & 102 & & \\
\hline & ТРB & 0.29 & 12 & & & 0.5 & $\mathrm{AG}$ & 9.5 & & & 38.5 & & \\
\hline & TPB & 0.51 & 16.6 & & & 0.5 & $\mathrm{AG}$ & 9.5 & & & 64.8 & & \\
\hline & ТPB & 1.03 & 25.6 & & & 0.5 & $\mathrm{AG}$ & 9.5 & & & 80.6 & & \\
\hline & ТPB & 4.28 & 30.9 & & & 0.5 & $\mathrm{AG}$ & 9.5 & & & 87.6 & & \\
\hline
\end{tabular}


Table 1 (continued)

\begin{tabular}{|c|c|c|c|c|c|c|c|c|c|c|c|c|c|}
\hline References & $\begin{array}{l}\text { Test } \\
\text { type }\end{array}$ & $\begin{array}{l}\text { Test } \\
\text { age }\end{array}$ & $\begin{array}{l}f_{\mathrm{c}}^{\prime} \\
(\mathrm{MPa})\end{array}$ & $\begin{array}{l}F_{\mathrm{t}}^{\prime} \\
(\mathrm{MPa})\end{array}$ & $\begin{array}{l}E \\
(\mathrm{GPa})\end{array}$ & $w / c$ & $\begin{array}{l}\text { Aggregate } \\
\text { type }\end{array}$ & $\begin{array}{l}d_{\mathrm{a}} \\
(\mathrm{mm})\end{array}$ & $\begin{array}{l}K_{\mathrm{c}} \\
\left(\mathrm{MPa} \mathrm{m}{ }^{1 / 2}\right)\end{array}$ & $\begin{array}{l}\delta_{\text {CTODc }} \\
(\mathrm{mm})\end{array}$ & $\begin{array}{l}G_{\mathrm{F}} \\
(\mathrm{N} / \mathrm{m})\end{array}$ & $\begin{array}{l}G_{\mathrm{f}} \\
(\mathrm{N} / \mathrm{m})\end{array}$ & $\begin{array}{l}c_{\mathrm{f}} \\
(\mathrm{mm})\end{array}$ \\
\hline & TPB & 9 & 35.1 & & & 0.5 & $\mathrm{AG}$ & 9.5 & & & 94.6 & & \\
\hline & TPB & 23 & 38.2 & & & 0.5 & $\mathrm{AG}$ & 9.5 & & & 98.1 & & \\
\hline \multirow[t]{17}{*}{ [94] } & TPB & 0.5 & 1.65 & & & 0.53 & SRG & 19.1 & 0.157 & & & & 0.9 \\
\hline & ТPB & 1 & 4.9 & & & 0.53 & SRG & 19.1 & 0.556 & & & & 4 \\
\hline & ТРB & 7 & 14.3 & & & 0.53 & SRG & 19.1 & 0.636 & & & & 5.3 \\
\hline & TPB & 21 & 21.2 & & & 0.53 & SRG & 19.1 & 0.844 & & & & 10.7 \\
\hline & ТPB & 28 & 21.4 & & & 0.53 & SRG & 19.1 & 0.928 & & & & 16.3 \\
\hline & ТPB & 1 & & & & 0.53 & SRG & 19.1 & 0.757 & & & & 35.8 \\
\hline & ТРВ & 1 & & & & 0.51 & SRG & 38.1 & 0.761 & & & & 38.4 \\
\hline & TPB & 1 & & & & 0.41 & SRG & 38.1 & 1.08 & & & & 85.1 \\
\hline & ТРВ & 1 & & & & 0.6 & SRG * & 19.1 & 0.67 & & & & 9.1 \\
\hline & ТРB & 1 & & & & 0.6 & SRG * & 19.1 & 0.806 & & & & 49.5 \\
\hline & ТРB & 1 & & & & 0.42 & $\mathrm{CL}$ & 19.1 & 1.56 & & & & 121 \\
\hline & TPB & 1 & & & & 0.44 & $\mathrm{CL}$ & 38.1 & 1.84 & & & & 229 \\
\hline & ТPB & 1 & & & & 0.46 & $\mathrm{CL}$ & 38.1 & 1.03 & & & & 90.7 \\
\hline & ТРВ & 1 & & & & 0.46 & DM & 38.1 & 0.95 & & & & 56.4 \\
\hline & TPB & 1 & & & & 0.39 & SRG & 25.4 & 0.788 & & & & 50.3 \\
\hline & TPB & 1 & & & & 0.39 & SRG & 38.1 & 0.755 & & & & 14.2 \\
\hline & ТРВ & 1 & & & & 0.39 & CL & & 0.909 & & & & 33.3 \\
\hline
\end{tabular}

$\omega_{G \mathrm{~F}}$ are the coefficients of variation of the ratios $G_{\mathrm{f}}^{\text {test }} / G_{\mathrm{f}}$ and $G_{\mathrm{F}}^{\text {test }} / G_{\mathrm{F}}$, for which a normal distribution may be assumed, and $\omega_{c \mathrm{f}}$ is the coefficient of variation of $c_{\mathrm{f}}^{\text {test }} / c_{\mathrm{f}}$, for which a lognormal distribution should be assumed $\left(\omega_{c \mathrm{f}}\right.$ is approximately equal to the standard deviation of $\ln c_{\mathrm{f}}$ ). The mean critical crack-tip opening displacement is then predicted as

$\delta_{\mathrm{CTOD}}=\sqrt{\frac{32}{\pi} \frac{G_{\mathrm{f}} c_{\mathrm{f}}}{E^{\prime}}}$.

It cannot be overemphasized that these simple formulae are intended only for preliminary design and for the analysis of structures with a low fracture sensitivity. Impor- tant and sensitive structures, though, should always be checked by finite element analysis based on fracture tests of notched specimens.

\section{Comparison of statistical distributions of errors}

Fig. 2 shows the probability density distributions of $G_{\mathrm{f}}$ and $c_{\mathrm{f}}$ for Sets I, II, and III, under the initial assumption that these data sets follow the normal distribution. To decide which distribution is best, it is better to consider the cumulative probability distributions and plot them on the so-called probability papers, i.e., papers that have the scales

Table 2

Notations in Table 1

\begin{tabular}{|c|c|c|c|c|c|}
\hline \multicolumn{6}{|c|}{ Test type } \\
\hline $\mathrm{CC}$ & compact compression & DTB & double torsion beam & NT & edge-notched tension \\
\hline CNR & bent circumference notched round bar & DTT & direct tension & OSB & one-size beam \\
\hline $\mathrm{CT}$ & compact tension & $\mathrm{EC}$ & eccentric compression & Plates & notched plates \\
\hline CuWS & cubical wedge splitting & FPB & four-point bend & ST & split-tension \\
\hline CyWS & cylindrical wedge splitting & FT & flexural tension & TDCB & tapered double-cantilever beam \\
\hline DCB & double cantilever beam & $\mathrm{NC}$ & notched cylinder & ТPB & three-point bend \\
\hline \multicolumn{6}{|c|}{ Aggregate type } \\
\hline $\mathrm{AG}$ & angular granite & $\mathrm{EC}$ & expanded clay & PG & pea gravel \\
\hline BA & basalt & FGG & fine-grained gabbro & Q & quartzite \\
\hline $\mathrm{CA}$ & crushed aggregate & GF & fine-grained granite & QG & quartzite gravel \\
\hline $\mathrm{CB}$ & crushed basalt & GLA & glacial deposit gravel & QS & quartz sand \\
\hline $\mathrm{CBA}$ & cold-bonded aggregate & GM & medium grained granite & RGRA & river gravel \\
\hline CGRA & crushed gravel & GN & gneiss & $\mathrm{RhR}$ & Rhine river sand and gravel \\
\hline CL & crushed limestone & GQS & greased quartz sand & RRG & rounded river gravel \\
\hline $\mathrm{CM}$ & crushed marble & GR & granite & $\mathrm{SA}$ & sintered gravel \\
\hline CQ & crushed quartzite & GRA & gravel & SCG & siliceous-calcareous gravel \\
\hline CRG & crushed river gravel & GREY & greywacke & SRG & siliceous river gravel \\
\hline $\mathrm{CS}$ & crushed stone & LI & limestone & SRG* & mixed SRG and CSS \\
\hline CSS & crushed sand stone & NA & natural aggregate & SRS & siliceous river sand \\
\hline DB & diabase & NRS & natural river sand & & \\
\hline DM & dolomite & OS & Ottawa sand & & \\
\hline
\end{tabular}


transformed in a manner that makes the assumed distribution a straight line. If the data scatter were captured by the distribution perfectly, all the data would fall on the straight line. Thus, the correct distribution is that for which the data plot in the probability paper comes the closest to a straight line.

Aside from the normal (Gaussian) distribution, other well-known probability distributions were checked for each set using the appropriate probability papers, including the Weibull (min), lognormal, and Gumbel (max) distributions. The plots of the cumulative distribution of empirical frequency or probability of the present data on the corresponding probability papers are shown in Fig. 7 for $G_{\mathrm{f}}$ data obtained from SEM, TPM, or ECM (Set I), in Fig. 8 for $G_{\mathrm{F}}$ data obtained by the WFM (Set II), and in Fig. 9 for $c_{\mathrm{f}}$ data.

The pair of thin lines in each plot represents the lower and upper confidence limits for the $5 \%$ and $95 \%$ probability
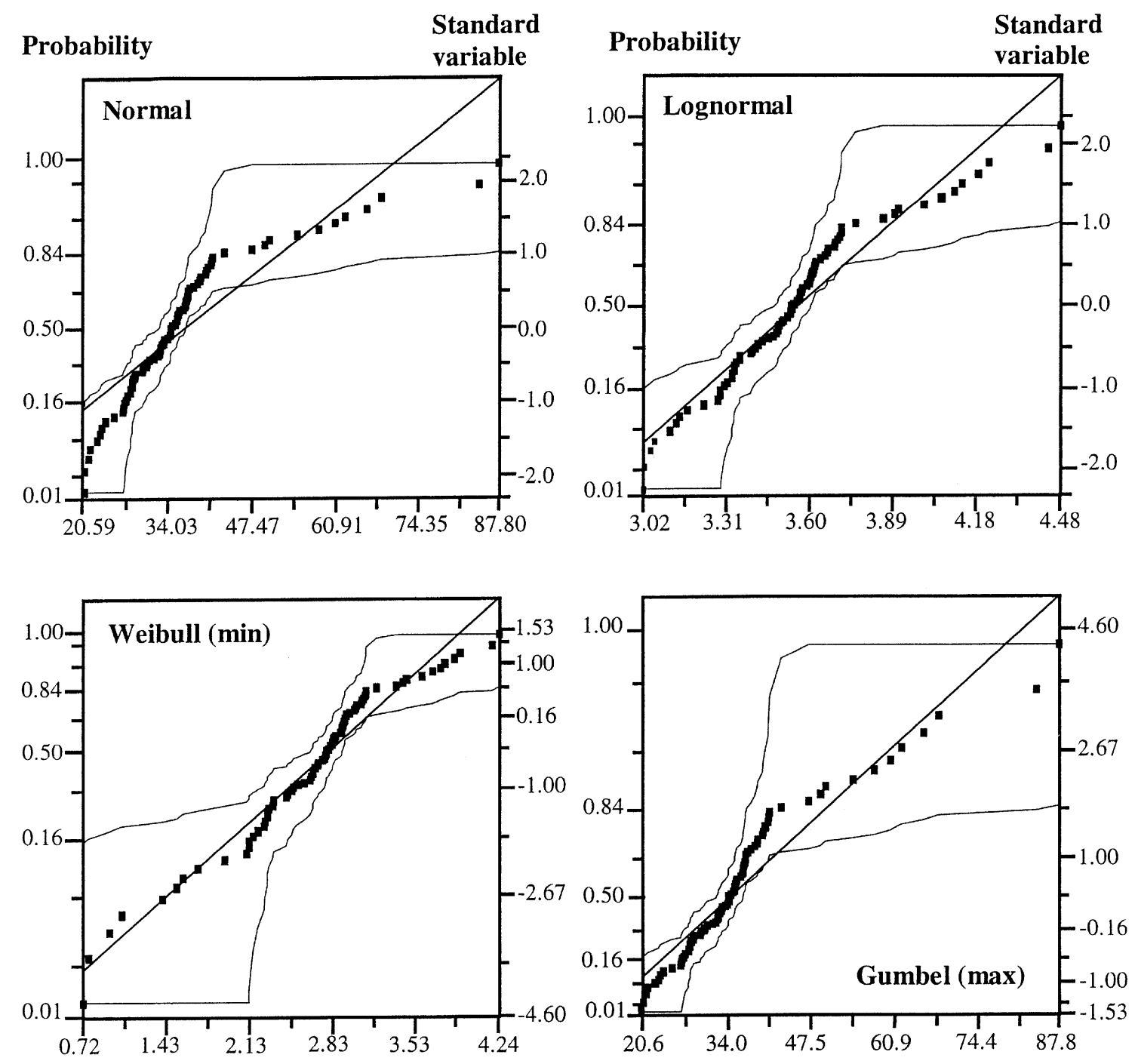

Observations of fracture energy $\mathbf{G}_{\mathbf{f}}$

cut-offs (they are calculated on the basis of the Kolmogorov-Smirnov distribution from the deviations of the empirical distribution from the parent distribution). If the distribution were followed by the data perfectly, the data would fall on the straight line shown. The best distribution is that for which the data lie the closest to the straight line. As seen, the plots closest to a straight line are obtained for the following distributions:

1. minimum Weibull distribution for Set I (SEM, TPM, ECM) (Fig. 7);

2. minimum Weibull or maximum Gumbel distribution for Set II (work-of-fracture) (Fig. 8).

3. lognormal distribution for $c_{\mathrm{f}}$ (Fig. 9).

As seen in Figs. 7-9, the data on $G_{\mathrm{f}}, G_{\mathrm{F}}$, and $c_{\mathrm{f}}$ obtained from Sets I and II are not well represented by the normal (Gaussian) distribution. Overall, the minimum Weibull

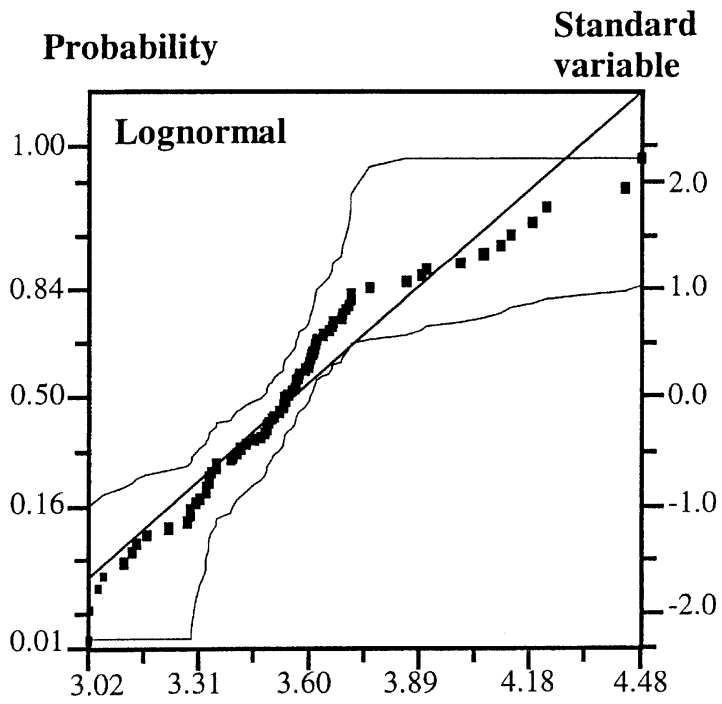

Fig. 7. Cumulative frequency plots of $G_{\mathrm{f}}$ on various probability papers for Set I (SEM, TPM, and ECM). 

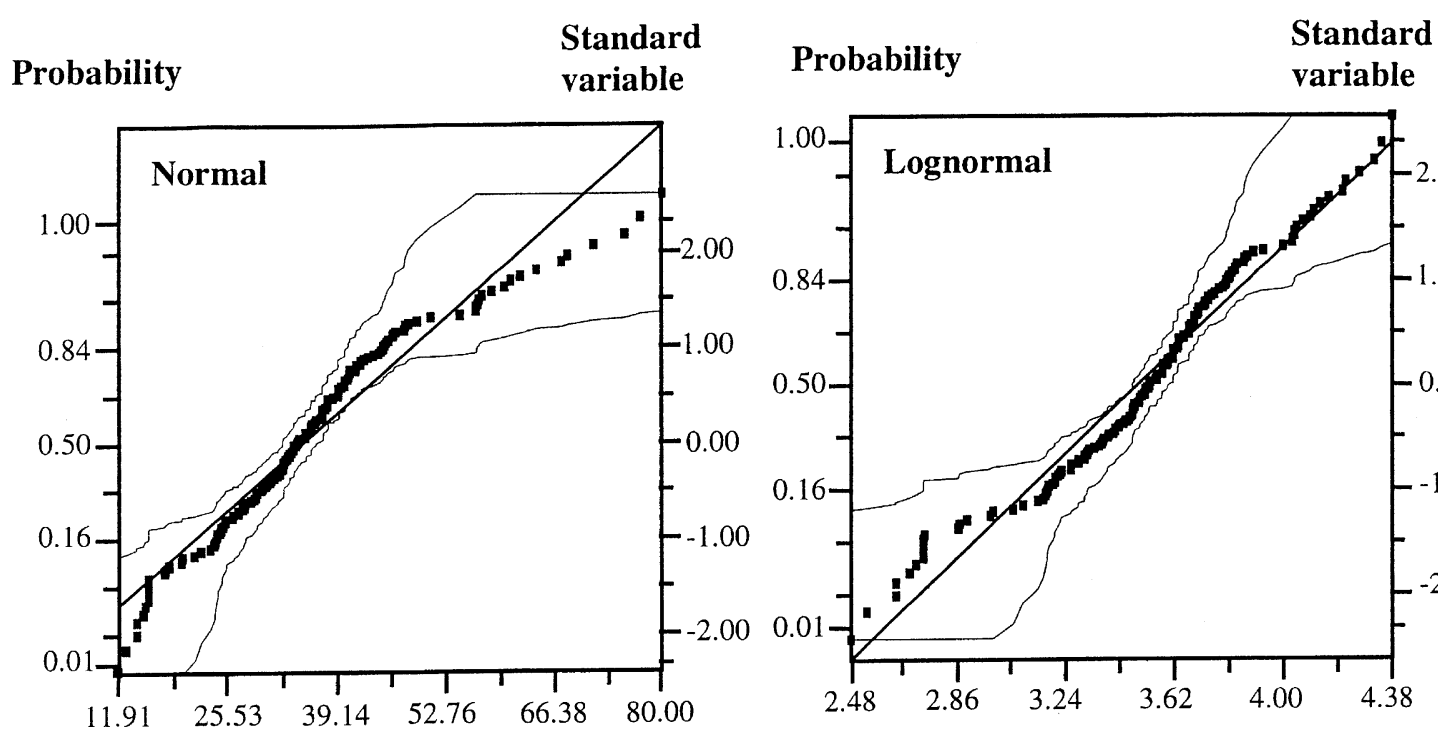

Standard
variable
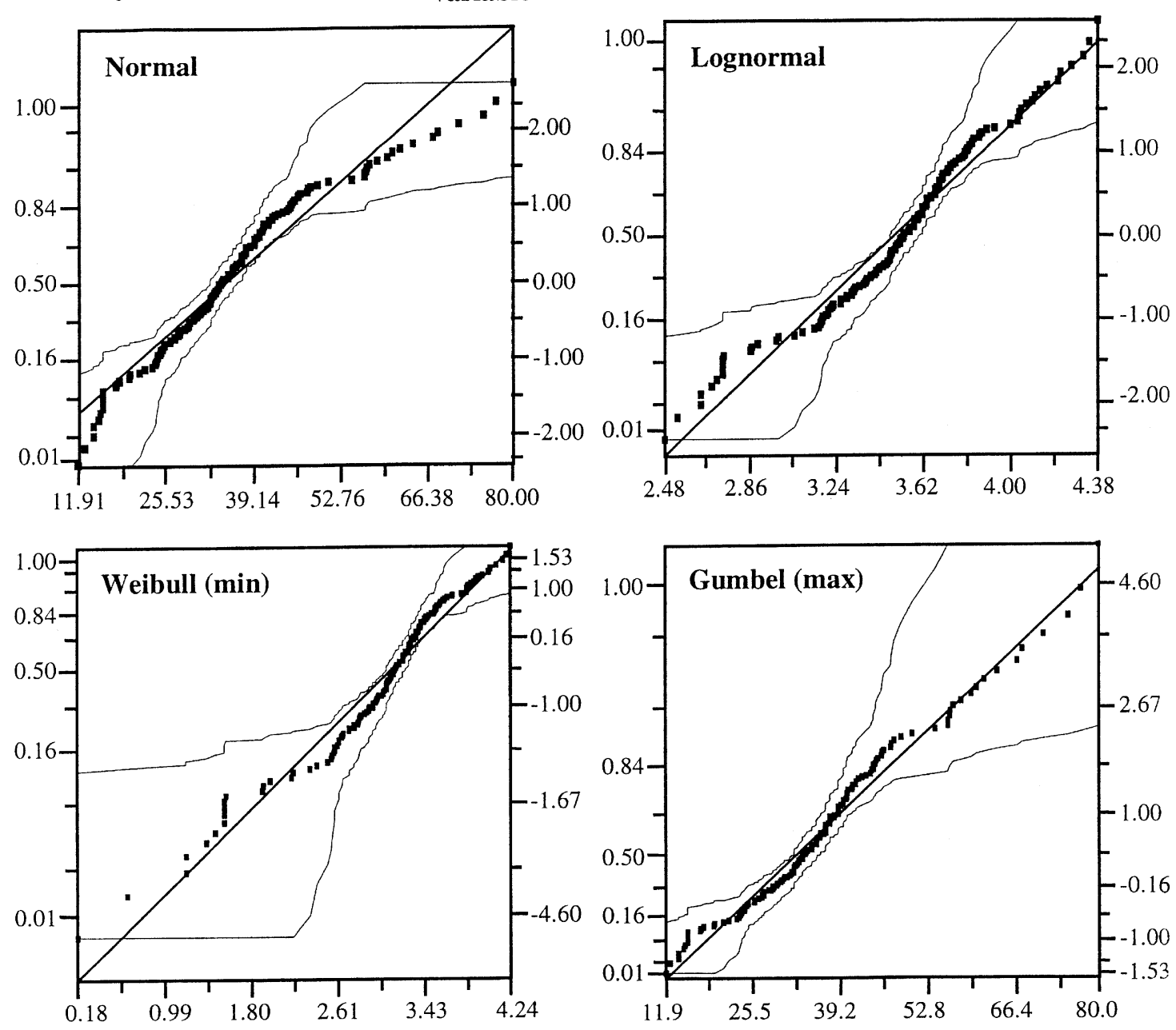

Observations of fracture energy $\mathbf{G}_{\mathbf{f}}$

Fig. 8. Cumulative frequency plots of $G_{\mathrm{F}}$ on various probability papers, for Set II (work-of-fracture).

distribution appears to be the closest to the straight line. The lognormal distribution is nearly as close as Weibull for $G_{\mathrm{F}}$, but distinctly worse for $G_{\mathrm{f}}$. For $c_{\mathrm{f}}$, the lognormal distribution is the best.

\section{Implications for the choice of testing method for a standard}

The present statistical study reveals that $G_{\mathrm{f}}$ is much less scattered than $G_{\mathrm{F}}$. This point is relevant to the choice of testing method for the testing standard, which has been debated for over a dozen years.

The high scatter of the results obtained with the WFM is explained partly by the difficulties in achieving independence of the results from the specimen size and the test setup, partly by a higher statistical variability of the tail of the softening load-deflection diagram, and partly by the uncertainty in extrapolating the tail to zero stress [76]. The fracture parameters measured by the SEM have also the important advantage that they are size and shape independent, by definition (this is of course true only within the size range for which the size effect law used is accurate, but this range encompasses the entire range of practical testing). For the related methods TPM and ECM, this is true only in the asymptotic sense, for large sizes only.

With regard to the current debates, it should further be noted that the maximum loads of structures depend mainly on the initial tangent of the softening stress-separation curve, which is fully characterized by $G_{\mathrm{f}}$, and are almost independent of the tail of this curve, which determines the difference between $G_{\mathrm{F}}$ and $G_{\mathrm{f}}$. On the other hand, the prediction of the entire postpeak softening load-deflection curve of a structure, which is often of secondary interest for design, does depend on the tail of the stress-separation 


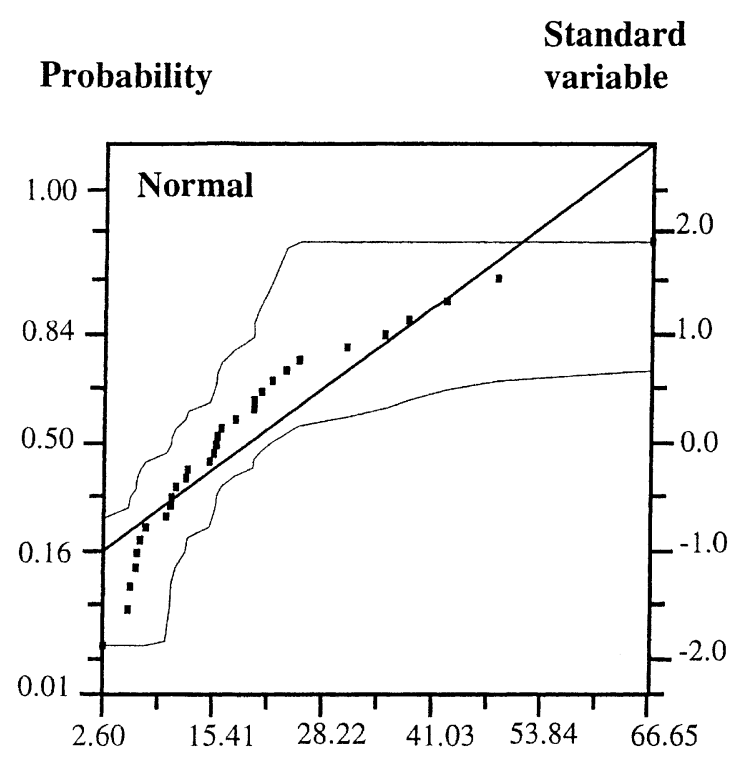

Probability $\begin{aligned} & \text { Standard } \\ & \text { variable }\end{aligned}$
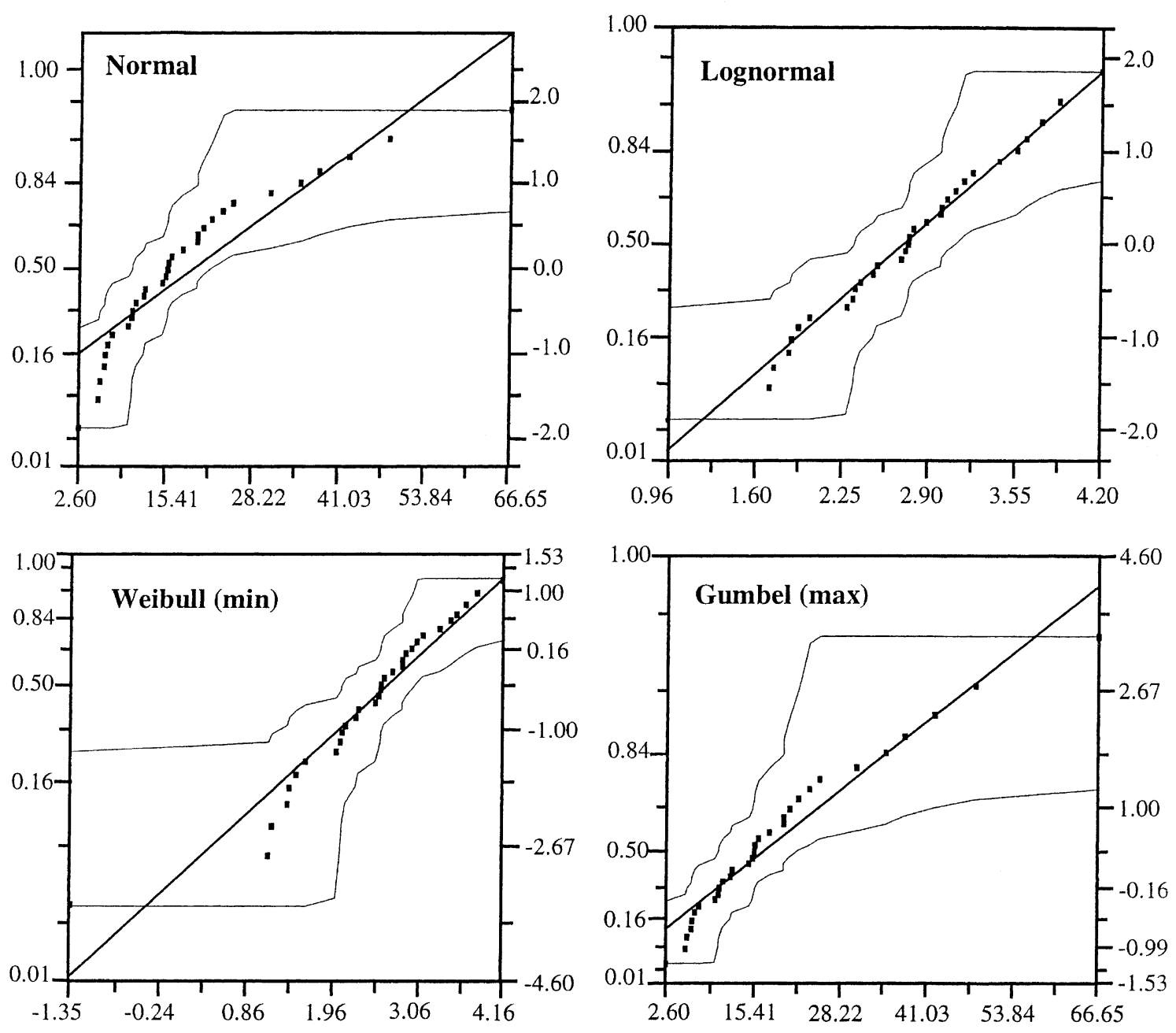

Observation of the critical effective crack extension $c_{f}$

Fig. 9. Cumulative frequency plots of $c_{\mathrm{f}}$ on various probability papers (SEM and TPM).

curve of the cohesive crack model, and thus on $G_{\mathrm{F}}$. In that case, the direct determination of $G_{\mathrm{F}}$ by the WFM has the advantage that it does not depend on the error of the approximation $G_{\mathrm{F}} \approx 2.5 G_{\mathrm{f}}$ (Eq. (9)).

It is important to keep in mind that $G_{\mathrm{f}}$ and $G_{\mathrm{F}}$ are two different material characteristics determining the initial slope and the tail of the stress-separation curve of the cohesive crack model. $G_{\mathrm{F}}$ can be estimated from $G_{\mathrm{f}}$ and vice versa, but not accurately. Ideally, both $G_{\mathrm{f}}$ and $G_{\mathrm{F}}$ should be measured and used in structural analysis for calibrating the initial slope and the tail of the cohesive crack model or crack band model.

There is, however, a widespread tendency to measure only one of these two fracture energies. In that case, if the cohesive crack model is to be used in structural analysis, the shape of the stress-separation diagram must be fixed in advance (if a bilinear softening diagram is adopted, this for example means fixing the ratios $G_{\mathrm{F}} / G_{\mathrm{f}}$ and $\sigma_{\text {knee }} / f_{\mathrm{t}}^{\prime}$, where $\sigma_{\text {knee }} / f_{\mathrm{t}}^{\prime}$ is the stress at the point of slope change; Fig. 1).

Among civil engineers, there is currently a widespread preference to measure and use only $G_{\mathrm{F}}$. This might be explained by the fact that the WFM and the use of the cohesive crack model in finite element programs can be understood even by civil engineers who have received no education in fracture mechanics. This cannot be said about the SEM or TPM. Although these methods also can be used by an engineer with no such education, their understanding requires at least elementary acquaintance with fracture mechanics. The choice of the testing standard, however, should be objective. It should not depend on the inadequacy of the current education.

At the (pre-FraMCoS-2) workshop of European and American specialists in Cardiff in 1995, organized by 
B.I.G. Barr and S.E. Swartz, it was agreed that the testing standard should specify two levels of testing. At Level II, recommended for structures of high sensitivity to fracture and size effect, both $G_{\mathrm{F}}$ and $G_{\mathrm{f}}$ (or $K_{\mathrm{c}}$ ) should be directly measured, while at Level I, appropriate for normal structures, only one of the two needs to be tested (measurements confined to the maximum load region and ignoring the tail were recommended for Level I at that workshop). If the cohesive crack model is calibrated by a Level I test, one must of course assume in advance the shape of the softening-stress separation curve, i.e., fix the ratios $G_{\mathrm{F}} / G_{\mathrm{f}}$ and $\sigma_{\text {knee }} f_{\mathrm{t}}^{\prime}$ based on prior knowledge.

Sticking to objective rational arguments only, should the Level I test measure $G_{\mathrm{F}}$ or $G_{\mathrm{f}}$ ? The prime argument should be that of accuracy, of minimizing the statistical uncertainty. Then, based on the present study, the answer is clear-Level I should involve the testing of $G_{\mathrm{f}}$, and $G_{\mathrm{F}}$ should then be estimated from $G_{\mathrm{f}}$, e.g., as $G_{\mathrm{F}} \approx 2.5 G_{\mathrm{f}}$.

Because Level I testing necessitates the ratio $G_{\mathrm{f}} / G_{\mathrm{F}}$ to be fixed, the coefficient of variation of errors of the measured fracture energy will get imposed on the other fracture energy that is inferred. Thus, if the Level I test measures $G_{\mathrm{F}}$, then its coefficient of variation will get impressed on $G_{\mathrm{f}}$ (or the initial slope of the softening curve), i.e., $\omega_{G f}=\omega_{G F}=29.9 \%$. Consequently, the maximum loads of structures, even if calculated by the cohesive crack model, will be governed by a fracture energy value whose errors have the large coefficient of variation of $G_{\mathrm{F}}$.

On the other hand, if the Level I test measures $G_{\mathrm{f}}$ (or $K_{\mathrm{c}}$ ) and the cohesive crack model is calibrated by the measured $G_{\mathrm{f}}$, the maximum loads of structures will be governed by a fracture energy whose errors have the coefficient of variation of $G_{\mathrm{f}}$, which is $17.8 \%$, roughly 1.67 times smaller. This is no small advantage.

If only a few tests of the given concrete are carried out in the Level I test, only the mean is statistically reliable but $\omega_{G \mathrm{~F}}$ or $\omega_{G \mathrm{f}}$ is not. In that case, one would have to assume the coefficients of variation from the prior experimental evidence, which would mean using $\omega_{G \mathrm{~F}}=29.9 \%$ or $\omega_{G f}=17.8 \%$, unless there are extensive prior data for the given concrete. If many, say 100 , tests of the given concrete are performed at Level $\mathrm{I}$, the value of $\omega_{G \mathrm{~F}}$ or $\omega_{G \mathrm{f}}$ can be determined from the tests of the given concrete alone. That value may be expected to be considerably reduced compared to the preceding values because concretes of different compositions are not mixed into one set. But both coefficients of variation will likely be reduced by the same ratio, e.g., to $\omega_{G \mathrm{~F}}=20 \%$ and $\omega_{G \mathrm{f}}=12 \%$. Thus, the advantage of using $G_{\mathrm{f}}$ rather than $G_{\mathrm{F}}$ for the Level I test must be assumed to be preserved (it is of course not entirely inconceivable that, in testing of one and the same concrete, the ratio of $\omega_{G \mathrm{~F}} / \omega_{G \mathrm{f}}$ is different and less unfavorable to $G_{\mathrm{F}}$ than found here, but this would have to be demonstrated by extensive statistically reliable test data for one concrete).

\section{Conclusions}

1. Although the statistical variations of the fracture energy of concrete and the effective size of the fracture process exhibit high random scatter, some clear statistical trends can be discerned.

2. Approximate statistical prediction of the fracture energy and of the order of magnitude of the effective length of the fracture process zone can be based on the standard compression strength of concrete, the maximum aggregate size, the aggregate shape (river or crushed aggregate), and the water-cement ratio. Among these parameters, the first two appear to be the most important for the fracture energy, and the last the least. In the case of $c_{\mathrm{f}}$, the maximum aggregate size appears to be by far the most important parameter, and the compressive strength the least. However, this is true only if the statistical correlation among these two parameters is ignored.

3. Formulae predicting the mean fracture energy $G_{\mathrm{f}}$ or $G_{\mathrm{F}}$ and the mean effective length $c_{\mathrm{f}}$ of the fracture process zone have been established. These formulae should be used in the statistical sense, taking into account the established coefficients of variation of $G_{\mathrm{f}}$ or $c_{\mathrm{f}}$. Structural designs should be made for a certain specified probability cutoff based on assuming a normal or Weibull distribution for the fracture energy, and lognormal distribution for the effective length of the fracture process zone. The corresponding values of the critical crack-tip opening displacement and of fracture toughness can be deduced from well-known formulae.

4. If all the important influencing parameters were known, it would have to be possible to be cast the prediction formulae in a dimensionless form. At present, however, this does not seem possible. It follows that not all the relevant parameters are known and further research is needed.

5. The coefficient of the data deviations from the mean prediction formula is much higher (1.67 times higher) for the fracture energy $G_{\mathrm{F}}$ measured by the WFM than it is for the fracture energy $G_{\mathrm{f}}$ measured by the SEM. The reason can be either that the $G_{\mathrm{F}}$, per se, has a higher degree of uncertainty, or that predicting the mean for $G_{\mathrm{F}}$ is harder than it is for $G_{\mathrm{f}}$. Although it remains to clarify the main reason, it is likely that the first possible reason is valid at least to some extent, because the tail of the softening stress-separation curve of the cohesive crack model is more uncertain than the initial tangent of that curve.

6. $G_{\mathrm{f}}$ and $G_{\mathrm{F}}$ are different fracture parameters. Both are needed to properly calibrate the softening stress-separation curve $-G_{\mathrm{f}}$ the initial slope and $G_{\mathrm{F}}$ the tail portion. Although they are partially correlated, ideally they should both be measured. For the sake of simplicity, however, the so-called Level I test now debated would measure only one. Logically, it should be $G_{\mathrm{f}}$. One argument for $G_{\mathrm{f}}$ has been that the most important practical application, which is 
the calculation of load capacity of structures, normally depends almost exclusively on the initial slope of the stress-separation curve, which in turn is directly determined by $G_{\mathrm{f}}$. The present study gives a second argument: If the initial slope is based on the measured $G_{\mathrm{f}}$, its errors have the coefficient of variation of $17.8 \%$, but if the initial slope is inferred (according to the assumed shape of the softening curve) from the measured $G_{\mathrm{F}}$, the coefficient of variation of the initial slope is $29.9 \%$, i.e., 1.67 times higher. Consequently, the load capacities of structures have much smaller statistical errors when their calculation is based on measured $G_{\mathrm{f}}$ rather than $G_{\mathrm{F}}$.

7. The high scatter of the existing test results suggests that future efforts should focus on improved prediction formulae involving further parameters of concrete composition and microstructure. Different formulae may have to be developed for high-strength concrete and lightweight concrete.

\section{Acknowledgments}

Financial support under NSF Grant No. CMS-9713944 to Northwestern University is gratefully acknowledged. Dr. D. Novák, Fulbright Scholar on leave from Technical University Brno, is thanked for some advice on the statistical analysis.

\section{Appendix A. Some influencing factors needing clarification}

In the case of high-strength concrete, the influence of the compressive strength on the fracture energy is not very clear. Gettu et al. [35], using the SEM, observed no difference in fracture energy $G_{\mathrm{f}}$ when high- and normalstrength concretes were compared. On the other hand, Gettu et al. [36], Karihaloo and Nallathambi [56], and Ouyang et al. [70] observed the fracture energy of high-strength concrete to be significantly higher than that of normalstrength concrete. However, the available data are too few for being conclusive, and further research is needed.

The effects of the aggregate on the fracture energy also require further study. The maximum aggregate size and the shape (crushed or smooth) are taken into account in the present formulae only very crudely. The role of the aggregates is certainly more complex. Other parameters such as the texture, mineralogy, and grading of the aggregate, and the proportion of aggregates in the concrete mix, are likely to have a nonnegligible influence on the fracture energy of concrete, especially since they affect the cement matrixaggregate interface.

The influence of the water-cement ratio also calls for further study. The data extracted from work-of-fracture measurements show no correlation between the water-tocement ratio and the fracture energy.

\section{Appendix B. Previous formulae for estimating fracture}

A simple formula for a mean estimate of the fracture energy has been developed by Bažant and Oh [21] on the basis of the maximum load data for notched specimen:

$G_{\mathrm{f}}=\left(2.72+0.0214 f_{\mathrm{t}}^{\prime}\right) f_{\mathrm{t}}^{\prime 2} \frac{d_{\mathrm{a}}}{E}$.

Formula (14), however, was based on very limited test data - only those reported in the literature prior to 1980 .

The test data reported in the literature up to the late $1980 \mathrm{~s}$ have been used to develop a mean estimate of $G_{\mathrm{F}}$ recommended by the Comité Euro-International du Béton proposed in its CEB-FIP Model Code [29]:

$G_{\mathrm{F}}=\left(0.0469 d_{\mathrm{a}}^{2}-0.5 d_{\mathrm{a}}+26\right)\left(\frac{f_{\mathrm{c}}^{\prime}}{10}\right)^{0.7}$

where $f_{\mathrm{c}}^{\prime}$ is in megapascals, $d_{\mathrm{a}}$ is in millimeters, and $G_{\mathrm{F}}$ in newtons per millimeter. A statistical comparison of this formula with the present data Set II is made in Fig. 6a and for comparison the present formula is shown in Fig. 6b. The coefficient of variation of the prediction errors of the CEB-FIP formula was found to be $33.3 \%$. Note that this is only 1.11 times higher than the value $29.9 \%$ for the present formula, despite the fact that the data set available for developing this formula was an order-of-magnitude smaller. ${ }^{1}$

\section{Appendix C. Why does the SEM give $G_{\mathrm{f}} \neq G_{\mathrm{F}}$ ?}

One might wonder why $G_{\mathrm{f}}$ and $G_{\mathrm{F}}$ should be different at all. During the 1980s, it used to be thought that $G_{\mathrm{f}}$ is the fracture energy determined by LEFM for an infinitely large specimen. Does this not imply $G_{\mathrm{f}}$ to be identical to $G_{\mathrm{F}}$ ? Not really.

The cohesive crack model with a long tail on its softening stress-separation curve corresponds, in the sense of the smeared-tip method [23], to a spectrum of fracture energies, $G_{\mathrm{f} 1}, G_{\mathrm{f} 2}, G_{\mathrm{f} 3}, \ldots$, associated with successively increasing orders of magnitude of the size scale (see Ref. [11], and in detail, Refs [12,14]). The corresponding "broad-range" size effect law is a sum of terms, each

\footnotetext{
${ }^{1}$ Karihaloo and Nallathambi [55] developed another formula (Eq. (a)), which reads:

$G_{\mathrm{f}}=\frac{f_{\mathrm{c}}^{\prime 2} b}{E} \alpha_{1}\left(\frac{d_{\mathrm{a}}}{b}\right)^{\alpha_{2}}\left(\frac{d}{L}\right)^{\alpha_{3}+\alpha_{4}(a / d)}$

where $\alpha_{1}=0.1431, \alpha_{2}=0.1713, \alpha_{3}=0.7666$, and $\alpha_{4}=0.4154$. However, the statistical basis was quite limited since the authors used only their own test data, all obtained on notched beams. Besides, this formula was obviously not intended to describe $G_{\mathrm{f}}$ as an objective material parameter because it involved the dimensional and geometric characteristics of the beam specimens.
} 
corresponding to one $G_{\mathrm{f} i}(i=1,2, \ldots)$. The value $G_{\mathrm{f} i}$ determines the location of the final asymptote of the $i$-th term in the logarithmic size effect plot.

The asymptote of the last term corresponds to $G_{\mathrm{F}}$. The asymptote of the first term (which may be written in the form of Bažant's 1984 original size effect law [7]) corresponds to $G_{\mathrm{fl}}=G_{\mathrm{f}}$, and $G_{\mathrm{f}}$ represents the area under the steep initial tangent of the stress-separation curve (Fig. 1).

Only the first term can get manifested in normal size effect testing of $G_{f}$, unless (hypothetically) the size range would exceed about 1:100 (as verified by finite element simulations in Ref. [18]). For the work-of-fracture measurement of $G_{\mathrm{F}}$, by contrast, the entire spectrum matters. The ratio $G_{\mathrm{F}} / G_{\mathrm{f}}=2.5$ means that, in the logarithmic size effect plot spanning many orders of magnitude of the specimen size, the asymptote of the last term should be shifted by log 2.5 to the right of the asymptote of the first term.

Numerical simulation show that, for fracture specimens and normal-size structures, the maximum load is reached when the crack-bridging stress at the notch tip is still quite large (above the stress value corresponding to the "knee" of a bilinear stress-separation curve). So, the cohesive crack is never opened enough for the tail stresses to materialize. If the cohesive crack model is replaced by a straight line corresponding to the initial tangent, the computations yield the same maximum load. Hence, the fracture energy corresponding to the area under this straight line governs. The stress at notch tip at maximum load vanishes at maximum load only when the size of the structure being simulated is enlarged by several orders of magnitude. Only then do the tail of the softening curve and the area under the complete curve matter for the maximum load.

\section{References}

[1] M. Alexander, Data from tests on notched concrete beams, private communication to Karihaloo and Nallathambi (see Ref. [54]), University of Witwatersrand, Johannesburg, 1987.

[2] B.I.G. Barr, T.J. Bear, A simple test of fracture toughness, Concrete, (1976) 25-27.

[3] B.I.G. Barr, E.B.D. Hasso, B.B. Sabir, The effect of test specimen size on the fracture toughness of concrete, Cem. Concr. Res. 15 (1985) 833-841.

[4] B.I.G. Barr, B.B. Sabir, Fracture toughness testing by means of the compact compression test specimen, Mag. Concr. Res. 37 (1985) $88-94$.

[5] A. Bascoul, Private communication to Karihaloo and Nallathambi (see Ref. [54]), University of Paul-Sabatier, Toulouse, France, 1987.

[6] Z.P. Bažant, Instability, ductility and size effect in strain-softening concrete, J. Eng. Mech. Div., Am. Soc. Civ. Eng. 102 (EM2) (1976) 331-344; discussion: 103, 357-358, 775-777; 104, 501-502.

[7] Z.P. Bažant, Size effect in blunt fracture: Concrete, rock, metal, J. Eng. Mech., Am. Soc. Civ. Eng. 110 (1984) 518-535.

[8] Z.P. Bažant, Scaling laws in mechanics of failure, J. Eng. Mech., Am. Soc. Civ. Eng. 119 (9) (1993) 1828-1844.

[9] Z.P. Bažant, Discussion of 'Fracture mechanics and size effect of concrete in tension', by Tang et al. (1992), J. Struct. Eng., Am. Soc. Civ. Eng. 119 (8) (1993) 2555-2558.
[10] Z.P. Bažant, Analysis of work-of-fracture method for measuring fracture energy of concrete, J. Eng. Mech., Am. Soc. Civ. Eng. 122 (2) (1996) 138-144.

[11] Z.P. Bažant, Size effect on structural strength: A review, Arch. Appl. Mech. (Ing.-Arch) 69 (1999) 703-725.

[12] Z.P. Bažant, Scaling of Structural Strength, Hermes Scientific Publications, Oxford and Paris, 2002.

[13] Z.P. Bažant, Analysis of work-of-fracture method for measuring fracture energy of concrete, J. Eng. Mech., Am. Soc. Civ. Eng., (2) (1996) $138-144$.

[14] Z.P. Bažant, Concrete fracture models: Testing and practice, Report, Northwestern University, 2000; also in M. Elices (Ed.), Eng. Fract. Mech. (special issue) (2001), in press.

[15] Z.P. Bažant, L. Cedolin, Approximate linear analysis of concrete fracture by R-curves, J. Struct. Eng., Am. Soc. Civ. Eng. 110 (6) (1984) 1336-1355.

[16] Z.P. Bažant, R. Gettu, M.T. Kazemi, Identification of nonlinear fracture properties from size effect tests and structural analysis based on geometry-dependent R-curves, Int. J. Rock Mech. Min. Sci. Geomech. Abstr. 28 (1) (1991) 43-51.

[17] Z.P. Bažant, M.T. Kazemi, Size effect in fracture of ceramics and its use to determine fracture energy and effective process zone length, J. Am. Ceram. Soc. 73 (7) (1990) 1841-1853.

[18] Z.P. Bažant, Y.-N. Li, Stability of cohesive crack model: Part II. Eigenvalue analysis of size effect on strength and ductility of structures, Trans. ASME, J. Appl. Mech. 62 (1995) 965-969 (December).

[19] Z.P. Bažant, D. Novák, Energetic-statistical size effect in quasibrittle failure at crack initiation, ACI Mater. J. 97 (3) (2000) 381-392.

[20] Z.P. Bažant, J.K.K. Kim, P.A. Pfeiffer, Nonlinear fracture properties from size effect tests, J. Struct. Eng., Am. Soc. Civ. Eng. 112 (2) (1986) 289-307.

[21] Z.P. Bažant, B.H. Oh, Crack band theory for fracture of concrete, Mater. Struct. 16 (1983) 155-177.

[22] Z.P. Bažant, P.A. Pfeiffer, Determination of fracture energy from size effect and brittleness number, ACI Mater. J. 84 (6) (1987) 463-480.

[23] Z.P. Bažant, J. Planas, Fracture and Size Effect in Concrete and Other Quasibrittle Materials, CRC Press, Boca Raton, FL, 1998.

[24] Z.P. Bažant, Q. Yu, Choice of concrete fracture test for a standard, Structural Engineering Report 01-10/C699c, Northwestern University, Am. Soc. Civ. Eng. (2001). Int. J. of Fracture (submitted for publication).

[25] A. Carpinteri, Experimental determination of fracture toughness parameters $K_{I \mathrm{c}}$ and $J_{I \mathrm{c}}$ for aggregative materials, in: D. François (Ed.), Advances in Fracture Research, Proc. 5th Int. Conf. Fract., Cannes, France, 1981.

[26] D.M. Catalano, A.R. Ingraffea, Concrete fracture: A linear elastic fracture mechanics approach, Report No. 82-1, Department of Structural Engineering, Cornell University, 1982, p. 161.

[27] T.P. Chang, M.M. Shieh, Fracture properties of lightweight concrete, Cem. Concr. Res. 26 (2) (1996) 181-188.

[28] T.P. Chang, K.L. Tsao, B.R. Lin, Effect of aggregate on fracture properties of high-performance concrete, Fracture Mechanics of Concrete Structures, Proceedings of the FRAMCOS-3, AEDIFICATIO Publishers, Freiburg, Germany, 1995, pp. 151-160.

[29] Comité Euro-International du Béton, CEB-FIP Model Code 1990, Thomas Telford, London, 1991.

[30] M. Elices, H. Corres, J. Planas, Experimental results of fracture energy of concrete for different specimen sizes, Report to RILEM TC 50-FMC, Madrid, 1987.

[31] M. Elices, G.V. Guinea, J. Planas, Measurement of the fracture energy using three-point bend tests: Part 3. Influence of cutting the $P-\delta$ tail, Mater. Struct. 25 (1992) 327-334.

[32] K.M. El-Sayed, G.V. Guinea, C. Rocco, J. Planas, M. Elices, Influence of aggregate shape on the fracture behaviour of concrete, Fracture Mechanics of Concrete Structures, Proceedings of the FRAMCOS-3, AEDIFICATIO Publishers, Freiburg, Germany, 1998.

[33] V.M. Entov, V.I. Yagust, Experimental investigation of laws govern- 
ing quasi-static development of macrocracks in concrete, Mech. Solids (Transl. From Russ.) 10 (4) (1975) 87-95.

[34] G. Ferrara, Determination of fracture energy of concrete by means of three-point bend tests on notched beams, Italian Electricity Board (ENEL-DSR-CRIS), Milano, 1987.

[35] R. Gettu, Z.P. Bažant, M.E. Karr, Fracture properties and brittleness of high-strength concrete, ACI Mater. J. 87 (6) (1990) 608-618.

[36] R. Gettu, V.O. Garcia-Alvarez, A. Aguado, Effect of aging on the fracture characteristics and brittleness of a high-strength concrete, Cem. Concr. Res. 28 (3) (1998) 349-355.

[37] G. Giacco, C. Rocco, R. Zerbino, The fracture energy $\left(G_{\mathrm{F}}\right)$ of high-strength concretes, Mater. Struct. 26 (1993) 381-386.

[38] O.E. Gjørv, S.I. Sørensen, A. Arnesen, Notch sensitivity and fracture toughness of concrete, Cem. Concr. Res. 7 (1977) 333-344.

[39] G.V. Guinea, J. Planas, M. Elices, On the influence of bulk dissipation on the average specific fracture energy of concrete, in: D. Firrao (Ed.), Fracture Behavior and Design of Materials and Structures, vol. 2, Engineering Materials Advisory Services (EMAS), Warltey, West Midlands, UK, 1990, pp. 715-720.

[40] G.V. Guinea, J. Planas, M. Elices, Measurement of the fracture energy using three-point bend tests: Part 1. Influence of experimental procedures, Mater. Struct. 25 (1992) 212-218.

[41] G.V. Guinea, J. Planas, M. Elices, A general bilinear fit for the softening curve of concrete, Mater. Struct. 27 (1994) 99-105.

[42] M. Hassanzadeh, The influence of the type of coarse aggregates on the fracture mechanical properties of high-strength concrete, Fracture Mechanics of Concrete Structures, Proceedings of the FRAMCOS-3, AEDIFICATIO Publishers, Freiburg, Germany, 1998, pp. $161-170$.

[43] B. Hillemeier, H.K. Hilsdorf, Fracture mechanics studies on concrete compounds, Cem. Concr. Res. 7 (1977) 523-537.

[44] A. Hillerborg, The theoretical basis of a method to determine the fracture energy $G_{\mathrm{F}}$ of concrete, Mater. Struct. 18 (1985) 291-296.

[45] A. Hillerborg, Results of three comparative test series for determining the fracture energy $G_{\mathrm{F}}$ of concrete, RILEM Technical Committee 50-Fracture Mechanics of Concrete, 1985.

[46] A. Hillerborg, M. Modéer, P.E. Petersson, Analysis of crack formation and crack growth in concrete by means of fracture mechanics and finite elements, Cem. Concr. Res. 6 (1976) 773-782.

[47] H.K. Hilsdorf, W. Brameshuber, Size effects in the experimental determination of fracture mechanics parameters, in: S.P. Shah (Ed.), Application of Fracture Mechanics to Cementitious Composites, NATO-ARW, Northwestern University, Evanston, USA, 1984, pp. 361-397.

[48] R. Hovarth, T. Persson, The influence of the size of the specimen on the fracture energy of concrete, Report TUBM-5005, Division of Building Materials, Lund Institute of Technology, Lund, Sweden, 1984.

[49] C.M.J. Huang, Finite element and experimental studies of stressintensity factors for concrete beams, Doctoral thesis, Kansas State University, Kansas, 1981.

[50] Y.S. Jenq, S.P. Shah, A fracture toughness criterion for concrete, Eng. Fract. Mech. 21 (5) (1985) 1055-1069.

[51] Y.S. Jenq, S.P. Shah, Two parameter fracture model for concrete, J. Eng. Mech. 111 (10) (1985) 1227-1241.

[52] R. John, S.P. Shah, Effect of high strength and rate of loading on fracture parameters of concrete, Fracture of Concrete and Rock: SEM-RILEM International Conference, Soc. for Experimental Mechanics, Houston, TX, USA, 1987, pp. 35-52.

[53] M.F. Kaplan, Crack propagation and the fracture of concrete, ACI J. 58 (5) (1961) 591-610.

[54] B.L. Karihaloo, P. Nallathambi, An improved effective crack model for the determination of fracture toughness of concrete, Cem. Concr. Res. 19 (1989) 603-610.

[55] B.L. Karihaloo, P. Nallathambi, Fracture toughness of plain concrete from three-point bend specimens, Mater. Struct. 22 (1989) 185-193.

[56] B.L. Karihaloo, P. Nallathambi, Notched beam test: Mode I fracture toughness, in: S.P. Shah, A. Carpinteri (Eds.), Fracture Mechanics Test Methods for Concrete, Chapman \& Hall, London, 1991, pp. 1-86.

[57] C.E. Kesler, D.J. Naus, J.L. Lott, Fracture mechanics-its applicability to concrete, Proceedings of the International Conference on the Mechanical Behavior of Materials, vol. 4, Society of Materials Science, London, 1972, pp. 113-124.

[58] R.H. Leicester, The size effect of notches', Proc. 2nd Australas. Conf. Mech. Struct. Mater, Melbourne, 1969, pp. 4.1-4.20.

[59] J.L. Malvar, G.E. Warren, Fracture energy for three-point-bend tests on single-edge-notched beams: Proposed evaluation, Mater. Struct. 20 (1987) 448-454.

[60] J.L. Malvar, G.E. Warren, Fracture energy for three-point-bend tests on single-edge-notched beams, Exp. Mech. 28 (3) (1988) 266-272.

[61] S. Mindess, The effect of specimen size on the fracture energy of concrete, Cem. Concr. Res. 14 (1984) 431-436.

[62] S. Mindess, F.V. Lawrence, C.E. Kesler, The J-integral as a fracture criterion for fiber reinforced concrete, Cem. Concr. Res. 7 (1977) $731-742$.

[63] S. Mindess, J.S. Nadeau, Effect of notch width on $K_{\text {Ic }}$ for mortar and concrete, Cem. Concr. Res. 6 (1976) 529-534.

[64] F. Moevenzadeh, R. Kuguel, Fracture of concrete, J. Mater., JMLSA 4 (3) (1969) 497-519.

[65] P. Nallathambi, Fracture behaviour of plain concretes, Doctoral dissertation, University of New Castle, Australia, 1986.

[66] P. Nallathambi, B.L. Karihaloo, Size dependent effects on fracture toughness of concrete, Advance in Fracture Research (Fracture 84), Proc. 6th Int. Conf. Fract. (ICF6), New Delhi, India, 1984, pp. $2785-2794$

[67] P. Nallathambi, B.L. Karihaloo, Determination of specimen-size independent fracture toughness of plain concrete, Mag. Concr. Res. 38 (135) (1986) 67-76.

[68] D.J. Naus, Applicability of linear-plastic fracture mechanics to Portland cement concretes, Doctoral thesis, University of Illinois at Urbana-Champaign, 1971.

[69] R.P. Ojdrovic, The notched cylinder for fracture toughness testing of concrete, Master's thesis, Duke University, 1986.

[70] C. Ouyang, T. Tang, S.P. Shah, Relationship between fracture parameters from two parameter model and from size effect model, Mater. Struct. 29 (1996) 76-86.

[71] P.E. Petersson, Fracture energy of concrete: Method of determination, Cem. Concr. Res. 10 (1980) 78-89.

[72] P.-E. Petersson, Crack growth and development of fracture zone in plain concrete and similar materials, Report No. TVBM-1006, Division of Building Materials Lund Institute of Technology, Lund, Sweden, 1981.

[73] J. Planas, M. Elices, Towards a measure of $G_{\mathrm{F}}$ : An analysis of experimental results, in: F.H. Wittman (Ed.), Fracture Toughness and Fracture Energy of Concrete, Elsevier, Amsterdam, 1986, pp. 381-390.

[74] J. Planas, M. Elices, Fracture criteria for concrete: Mathematical approximation and experimental validation, Eng. Fract. Mech. 35 (1990) 87-94.

[75] J. Planas, M. Elices, G.V. Guinea, Measurement of the fracture energy using three-point bend tests: Part 2. Influence of bulk energy dissipation, Mater. Struct. 25 (1992) 305-312.

[76] M.E. Refai, S.E. Swartz, Fracture behaviour of concrete beams in three-point bending considering the influence of size effects, Report No. 190, Engineering Experimental Station, Kansas State University, 1987.

[77] RILEM, Determination of the fracture energy of mortar and concrete by means of three-point bend tests on notched beams, Mater. Struct. 18 (1985) 285-290 (RILEM Draft Recommendation, TC 50-FMC Fracture Mechanics of Concrete).

[78] RILEM, Determination of fracture parameters $\left(K_{I c}\right.$ and $\left.C T D O_{c}\right)$ of plain concrete using three-point bend tests on beams, Mater. Struct. 23 (1990) 457-460 (RILEM Draft Recommendation, TC 89-FMT Fracture Mechanics of Concrete-Test Methods).

[79] RILEM, Size-effect method for determining fracture energy and 
process zone size of concrete, Mater. Struct. 23 (1990) 461-465 (RILEM Draft Recommendation, TC 89-FMT Fracture Mechanics of Concrete-Test Methods).

[80] P. Rossi, E. Brühwiler, S. Chhuy, Y.-S. Jenq, S.P. Shah, Fracture properties of concrete as determined by means of wedge splitting tests and tapered double cantilever beam tests, in: S.P. Shah, A. Carpinteri (Eds.), Fracture Mechanics Test Methods for Concrete, Chapman \& Hall, London, 1991, pp. 87-128.

[81] S.P. Shah, F.J. McGarry, Griffith fracture criterion and concrete, J. Eng. Mech. Div., Am. Soc. Civ. Eng 97 (EM6) (1971) 1663-1676.

[82] S.P. Shah, C. Ouyang, S. Marikunte, W. Yang, E. Becq-Giraudon, A method to predict shrinkage cracking of concrete, ACI Mater. J. 95 (4) (1999) 339-346.

[83] C. Sok, J. Baron, D. François, Mécanique de la rupture appliquée au bēton hydraulique, Cem. Concr. Res. 9 (1979) 641-648.

[84] P.C. Strange, A.H. Bryant, Experimental tests on concrete fracture, Proc. Am. Soc. Civ. Eng. 105 (EM2) (1979) 337-342.

[85] P.C. Strange, A.H. Bryant, The role of aggregate size in the fracture of concrete, J. Mater. Sci. 14 (1979) 1863-1868.

[86] T. Tang, Z.P. Bažant, Y. Sungchul, D. Zollinger, Variable-notch onesize method for fracture energy and process zone length, Eng. Fract. Mech. 55 (3) (1996) 383-404.

[87] T. Tang, C. Ouyang, S.P. Shah, A simple method for determining material fracture parameters from peak loads, ACI Mater. J. 93 (2) (1996) $147-157$.

[88] Y. Uchida, B.I.G. Barr, Tension softening curves of concrete determined from different test specimen geometries, Fracture Mechanics of Concrete Structures, Proceedings of the FRAMCOS-3, AEDIFICATIO Publishers, Freiburg, Germany, 1998, pp. 387-398.

[89] P.F. Walsh, Fracture of plain concrete. Indian Concrete J. 46 (11) (1972) 469-470, 476.

[90] M. Wecharatana, S.P. Shah, Resistance to crack growth in Portland cement composites, Report, Department of Material Engineering, University of Illinois at Chicago Circle, Chicago, IL, 1980.

[91] M. Wecharatana, S.P. Shah, Slow crack growth in cement composites, J. Struct. Div., Proc. Am. Soc. Civ. Eng. 108 (ST6) (1982) 1400-1413.

[92] F.H. Wittman, P.E. Roelfstra, H. Mihashi, Y.-Y. Huang, X.-H. Zhang, N. Nomura, Influence of age of loading, water-to-cement ratio and rate of loading on fracture energy of concrete, Mater. Struct. 20 (1987) $103-110$.

[93] B.J. Yu, F. Ansari, Method and theory for nondestructive determination of fracture energy in concrete structure, ACI Struct. J. 93 (5) (1996) 602-613.

[94] D.G. Zollinger, T. Tang, R.H. Yoo, Fracture toughness of concrete at early stages, ACI Mater. J. 90 (5) (1993) 463-471.

\section{Additional bibliography}

[95] B.I.G. Barr, W.T. Evans, R.C. Dowers, B.B. Sabir, The fracture toughness of concrete, in: D.R.J. Owen, A.R. Luxmoore (Eds.), Numerical Methods in Fracture Mechanics, Pineridge Press, Swansea, UK, 1980, pp. 737-749.

[96] B.I.G. Barr, W.T. Evans, R.C. Dowers, Fracture toughness of polypropylene fiber concrete, Int. J. Cem. Compos. Lightweight Concr. 3 (2) (1981) 115-122.

[97] T. Bear, B.I.G. Barr, Fracture toughness tests for concrete, Int. J. Fract. 13 (1977) 92-96.

[98] W. Brameshuber, H.K. Hilsdorf, Influence of ligament length and stress state on fracture energy of concrete, Eng. Fract. Mech. 35 (1-3) (1990) 95-106.

[99] J.H. Brown, Measuring the fracture toughness of cement paste and mortar, Mag. Concr. Res. 24 (81) (1972) 185-196.

[100] J.H. Brown, C.D. Pomeroy, Fracture toughness of cement paste and mortar, Cem. Concr. Res. 3 (1973) 475-480.

[101] E. Brühwiler, F.H. Wittman, The wedge splitting test, a new method of performing stable fracture mechanics test, Eng. Fract. Mech. 35 (1-3) (1990) 117-125.

[102] J. Glücklich, Fracture of plain concrete, J. Eng. Mech. Div., Am. Soc. Civ. Eng. 89 (1963) 127-138.

[103] G.V. Guinea, J. Planas, M. Elices, Correlation between the softening and the size effect curves, in: H. Mihashi, H. Okamura, Z.P. Bažant (Eds.), Size Effect in Concrete Structures, E.\&F.N. Spon, London, 1994, pp. 233-244.

[104] B. Harris J. Varlow, C.D. Ellis, The fracture behaviour of fibre reinforced concrete, Cem. Concr. Res. 2 (1972) 447-461.

[105] A. Hillerborg, Concrete fracture energy tests performed by 9 laboratories according to a draft RILEM recommendation, Report to RILEM TC50-FMC, Report TVBM-3015, Division of Building Materials, Lund Institute of Technology, Lund, Sweden, 1983.

[106] A. Hillerborg, Additional concrete fracture energy tests performed by 6 laboratories according to a draft RILEM recommendation, Report to RILEM TC50-FMC, Report TVBM-3017, Division of building materials, Lund Institute of Technology, Lund, Sweden, 1984.

[107] A. Hillerborg, Influence of beam size on concrete fracture energy determined according to a draft RILEM recommendation, Report to RILEM TC50-FMC, Report TVBM-3021, Division of Building Materials, Lund Institute of Technology, Lund, Sweden, 1985.

[108] S. Mindess, Effect of notch width on $K_{I c}$ for mortar and concrete, Cem. Concr. Res. 6 (1976) 529-534.

[109] P. Nallathambi, B.L. Karihaloo, Influence of slow crack growth on the fracture toughness of plain concrete, in: F.H. Wittman (Ed.), Proceedings of the International Conference on Fracture Toughness and Fracture Energy of Concrete, Elsevier, Amsterdam, 1986, pp. $271-280$.

[110] P. Nallathambi, B.L. Karihaloo, Stress intensity factor and energy release rate for three-point bend specimens, Eng. Fract. Mech. 25 (3) (1986) 315-321.

[111] P. Nallathambi, B.L. Karihaloo, B.S. Heaton, Effect of specimen and crack sizes, water-cement ratio and coarse aggregate texture upon fracture toughness of concrete, Mag. Concr. Res. 36 (1984) 227-236.

[112] P. Nallathambi, B.L. Karihaloo, B.S. Heaton, Various size effects in fracture of concrete, Cem. Concr. Res. 15 (1985) 117-126.

[113] D.J. Naus, J.L. Lott, Fracture toughness of Portland cement concretes, ACI J. 66 (1969) 481-498.

[114] R.P. Ojdrovic, H.J. Petroski, The cracked Brazilian test for fracture toughness testing of concrete, Int. J. Fract. 27 (1985) R75-R80.

[115] R.P. Ojdrovic, A.L. Stojimirovic, H.J. Petroski, Effect of age on splitting tensile strength and fracture resistance of concrete, Cem. Concr. Res. 17 (1987) 70-76.

[116] J.P. Romualdi, G.B. Batson, Mechanics of crack arrest in concrete, J. Eng. Mech. Div., Proc. Am. Soc. Civ. Eng. 89 (EM3) (1963) 147-168.

[117] V.E. Saouma, A.R. Ingraffea, D.M. Catalano, Fracture toughness of concrete: $K_{I c}$ revisited, J. Eng. Mech. Div., Proc. Am. Soc. Civ. Eng. 108 (EM6) (1982) 1152-1166.

[118] S.P. Shah, Fracture toughness of fiber reinforced concrete, Report, AFOSR, 1985, 82-0243.

[119] S.E. Swartz, K.K. Hu, M. Fartash, C.M.J. Huang, Stress intensity factors for plain concrete in bending-prenotched versus precracked beams, Report, Department of Civil Engineering, Kansas State University, Kansas, 1981.

[120] P.F. Walsh, Crack initiation in plain concrete, Mag. Concr. Res. 28 (94) (1976) 37-41.

[121] M. Wecharatana, Specimen size effect on non-linear fracture parameters in concrete, in: F.H. Wittman (Ed.), Fracture Toughness and Fracture Energy of Concrete, Elsevier, Amsterdam, 1986, pp. 437-440.

[122] M. Wecharatana, S.P. Shah, Nonlinear fracture mechanics parameters, Div. Civ. Eng. (1983) 463-480.

[123] F.H. Wittman, H. Mihashi, N. Nomura, Size effect on fracture energy of concrete, Eng. Fract. Mech. 35 (1-3) (1990) 107-115.

[124] L. Wu, X. Peng, Q. Chu, W. Lei, G. Bai, J. Yang, Fracture energy of lime-sand concrete and application of the acoustic emission technique, Mag. Concr. Res. 46 (166) (1994) 17-21. 